Andrews University

Digital Commons @ Andrews University

1987

\title{
Towards A Model Of Congregational Evangelistic Campaigns In The Seventh-day Adventist Churches In West Germany
}

Ekkehardt Muller

Andrews University

Follow this and additional works at: https://digitalcommons.andrews.edu/dmin

Part of the Practical Theology Commons

\section{Recommended Citation}

Muller, Ekkehardt, "Towards A Model Of Congregational Evangelistic Campaigns In The Seventh-day Adventist Churches In West Germany" (1987). Professional Dissertations DMin. 466.

https://dx.doi.org/10.32597/dmin/466

https://digitalcommons.andrews.edu/dmin/466

This Project Report is brought to you for free and open access by the Graduate Research at Digital Commons @ Andrews University. It has been accepted for inclusion in Professional Dissertations DMin by an authorized administrator of Digital Commons @ Andrews University. For more information, please contact repository@andrews.edu. 


\section{ABSTRACT}

TOWARDS A MODEL OF CONGREGATIONAL EVANGELISTIC CAMPAIGNS IN THE SEVENTH-DAY ADVENTIST CHURCHES IN WEST GERMANY

\section{by}

Ekkehardt Müller

Chairman: Garth Thompson 


\begin{abstract}
A Project Report

Andrews University

Seventh-day Adventist Theological Seminary
\end{abstract}

Title: TOWARDS A MODEL FOR CONGREGATIONAL EVANGELISTIC

CAMPAIGNS IN THE SEVENTH-DAY ADVENTIST CHURCHES

IN WEST GERMANY

Name of researcher: Ekkehardt Müller

Name and degree of faculty adviser: Garth Thompson, Ph.D. Date completed: July 1987

In the western world it is a great challenge for churches to reach secular persons. This is true especialIy for West Germany where only an almost insignificant percentage of the population attends church regularly. Traditional methods to win people for christ usually focus on this small percentage of people instead of on the vast majority of the unchurched people. Reaching the unchurched is a situation in which the laymen of the church are of special importance, for they are able to be in touch with persons clergymen will almost never 
reach. Thus laymen need to have a larger sphere of influence in the proclamation of the gospel. They need opportunities to use their gifts. Moreover, new approaches must be developed to meet the needs of the secular mind.

One approach is the congregational evangelistic campaign, a campaign prepared and implemented by the lay congregation including the public proclamation by groups of laymen. An analysis of the practice of this type of approach in the Seventh-day Adventist churches in West Germany, by means of twenty-two completed questionnaires and several personal interviews, reveals the following facts: (1) Although there are some weaknesses, pastors and churches are generally enthusiastic about this type of approach. (2) The open style and the focus on every-day problems are attractive to the secular mind. (3) An important factor is the building of relationships among church members and visitors. (4) As a side effect the church is activated. (5) The gifts of laymen are enhanced.

Although congregational evangelistic campaigns were already being held in west Germany, it seemed significant to study the method more thoroughly and to develop a model. This model describes the preparation, implementation, follow-up, and evaluation of this kind of campaign. Variables affecting outcomes, the role of the 
pastor, and combinations of congregational evangelism with other programs are discussed. The model gives special emphasis to the preparation phase, which contains a training program for selected laymen. The stress on preparation is necessary to guarantee an effective implementation and follow-up.

Although these campaigns use a somewhat uncommon approach, they are based on the biblical concept of evangelism. The advantages they have recommend them to be used more extensively. 
Andrews University

Seventh-day Adventist Theological Seminary

\title{
TOWARDS A MODEL OF CONGREGATIONAL EVANGELISTIC CAMPAIGNS IN THE SEVENTH-DAY ADVENTIST CFIURCHES IN WEST GERMANY
}

\author{
A Project Report \\ Presented in Partial Fulfillment \\ of the Requirements for the Degree \\ Doctor of Ministry
}

by

Ekkehardt Müller

July 1987 

TOWARDS A MODEL OF CONGREGATIONAL EVANGELISTIC

CAMPAIGNS IN THE SEVENTH-DAY ADVENTIST

CHURCHES IN WEST GERMANY

A project report

presented in partial fulfillment

of the requirements for the degree

Doctor of Ministry

by

Ekkehardt Müller

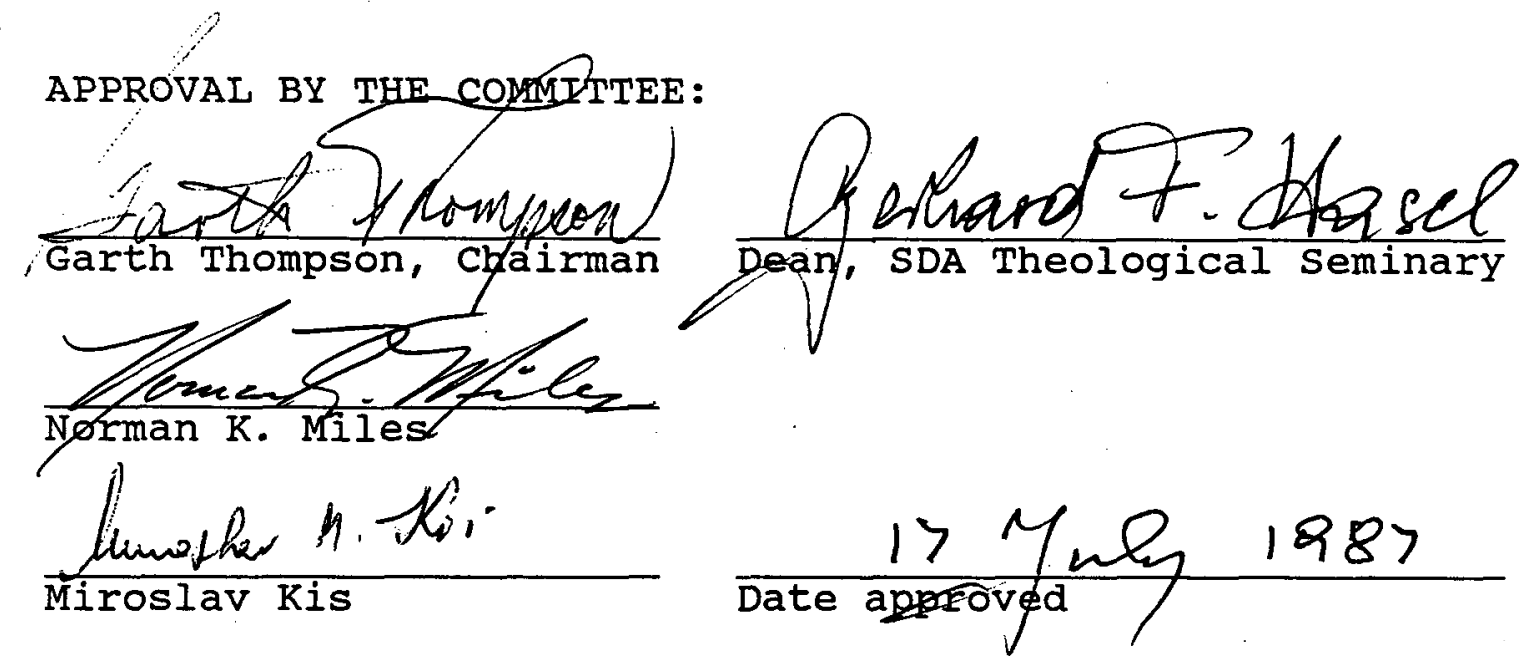


TABLE OF CONTENTS

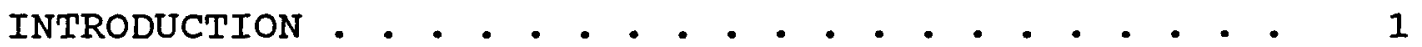

Chapter

I. AN EXAMINATION OF THE IMPORTANCE OF CONGREGATIONAL EVANGELISTIC CAMPAIGNS • • • • 4

The Importance of Evangelism in General • . 4

Linguistic Roots of Evangelism . . . . . 5 In the old Testament and in

Palestinian Judaism . . . . : . . 5

In the New Testament . . . . . . . 8

Summary . . . . . . . . . . . . . 15

"Evangelist" in the New Testament . . . 16

A spiritual gift . . . . . . . . . . 16

Timothy as evangelist . . . . . . . . 21

Philip as evangelist . . . . . . . . . . 24

Summary . . . . . . . . . . . . . . 27

Evangelism in Church History . . . . . . 31

The Apostolic time . . . . . . . . . 31

The first centuries A.D. . . . . . . . 32

Middle Ages, Reformation, and Pietism . 33

Modern times and the 20 th century . . . 35

E. G. White and evangelism . . . . . 39

Implications . . . . . . . . . . . . 41

Evangelistic methods . . . . . . . . . 44

Laity versus Clergy in Reaching

the Unreached .. . . . . . . . . . 46

Definitions ............... 46

Laity and clergy ............ 46

The unchurched . . . . . . . . . . 51

The Clergyman--His Problems

and opportunities . . . . . . . . 56

Clergyman's problems . . . . . . . . 56

clergyman's opportunities . . . . . . 61

The Layman--His Problems

and opportunities . . . . . . . . . 62

Layman's problems . . . . . . . . . 62

Layman's opportunities . . . . . . . 68

The Unchurched--Reaching Them for Christ . 71

Summary . . . . . . . . . . . . 77 
Conclusions for Congregational

Evangelistic Campaigns . . . . . . . . 79

Results of the Previous Study . . . . . 79

Problems with the Concept

of Lay Evangelism . . . . . . . . . 79

Presence ................ . 80

Proclamation . . . . . . . . . . 80

Persuasion . . . . . . . . . . . 81

Summary . . . . . . . . . . . . . . 85

Suggestions for Lay Evangelism . . . . . 86

II. A STUDY OF PREVIOUS CONGREGATIONAL

EVANGELISTIC CAMPAIGNS IN WEST GERMANY • • • 89

Report on Previous Congregational Evangelistic Campaigns as Described in the

Questionnaires and Interviews . . . . . 89

Report on the First Questionnaire . . . . 89

Report on the second Questionnaire . . . . 90

Analysis of the Reported Campaigns . . . . 91

Question 1 . . . . . . . . . . . . . 91

Question 2 . . . . . . . . . . . . . . 92

Question 3 . . . . . . . . . . . . . . 92

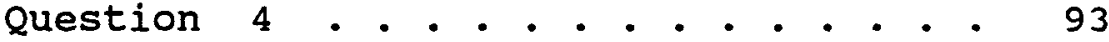

Question 5 . . . . . . . . . . . . . . 93

Question 6 . . . . . . . . . . . . . 95

Question 7 . . . . . . . . . . . . 96

Question 8 . . . . . . . . . . . . . . 97

Question 9 . . . . . . . . . . . 102

Question 10 . . . . . . . . . . . 105

Question 11 . . . . . . . . . . . . 106

Question 12 . . . . . . . . . . . . . 110

Question 13 . . . . . . . . . . . . . . 113

Question 14 . . . . . . . . . . . . . . 113

Question 15 . . . . . . . . . . . . . 114

Questions 16 and 17 . . . . . . . . 115

Question 18 . . . . . . . . . . . . . 116

Question 19 . . . . . . . . . . . 117

Question 20 . . . . . . . . . . . . . 119

Report on the Interviews . . . . . . . 120

Conclusions . . . . . . . . . . . . 125

Strengths of congregational

evangelistic campaigns ...... . 125

Weaknesses of congregational

evangelistic campaigns . . . . . . 126

III. A MODEL FOR CONGREGATIONAL EVANGELISTIC

CAMPAIGNS IN WEST GERMANY . . . . . . . . . . 128

Variables in Congregational Evangelistic

Campaigns 


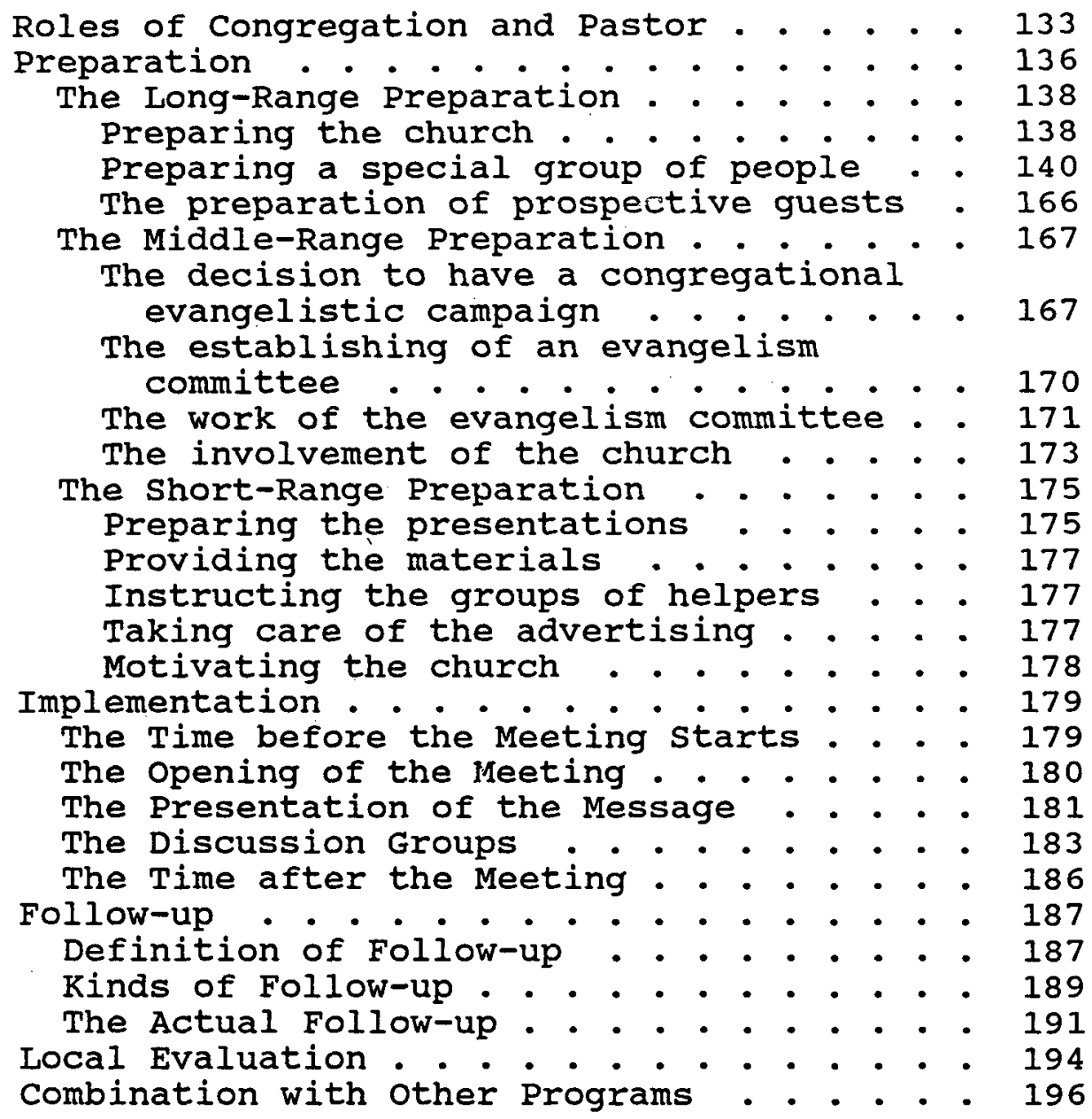

IV. CONCLUSIONS AND RECOMMENDATIONS • • . . . . . 198

Benefits of Congregational Evangelistic

Campaigns . . . . . . . . . . . . 198

Benefits for the Church . . . . . . 198

Benefits for the Guests .. . . . . . . 199

Benefits for the Team Members . . . . . 200

Recommendations Concerning Congregational

Evangelistic Campaigns . . . . . . . 201

Benefits Gained from This Project . . . . 204

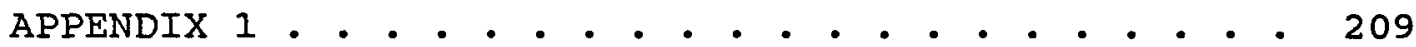

Letter to Ministers . . . . . . . . . . . . 209

Questionnaire on a Congregational Evangelistic

Campaign . . . . . . . . . . . . . . . 210

APPENDIX 2......................... 211

Letter No.2 to Ministers . . . . . . . . . . . 211 
Questionnaire No. 2 on Congregational

Evangelistic Campaigns... . . . . . . 213

APPENDIX 3....................... . 226

Questions for the Interview . . . . . . . . 226

APPENDIX 4 . • . . . . . . • . . . . . . . . 227

The Preparation of the Church . . . . . . . . 227

Invitation List for the Evangelistic Campaign . . 230

BIBLIOGRAPHY • • . . . . . . . . . . . . . 232

VITA . . . . . . . . . . . . . . . . . . 254 


\section{LIST OF TABLES}

1. Usage of Euaggel- in the New Testament . . . . 9

2. Usage of Keryx- in the New Testament . . . . . 14

3. Reasons for Choosing This Type of Campaign . . . 94

4. Objectives of the Campaign . . . . . . . . . 95

5. Preparation of the Church . . . . . . . . 98

6. Financial . . . . . . . . . . . . . . . . 99

7. Preparation of the Programs . . . . . . . 100

8. Preparation of the Public . . . . . . . . 101

9. Elements That Structured the Meetings . . . . 102

10. Proclamation and Discussion Groups . . . . . 103

11. Themes of the Meetings . . . . . . . . . 104

12. Number of Speakers per Meeting . . . . . . . 105

13. Follow-up . . . . . . . . . . . . 106

14. The Participation of the Church . . . . . . 107

15. Members Participation in Efforts . . . . . . 109

16. Numbers of Visitors . . . . . . . . . . 110

17. Scores Revealing Guest Attendance . . . . . 112

18. Methods by Which Non-SDAs Were Attracted . . . 113

19. Positive Effects on Churches . . . . . . . 114

20. Positive Effects on Non-SDAs . . . . . . . . 115 
21. Attitude towards Congregational Campaigns . . 115

22. Comparision to Traditional Campaigns . . . . 116

viii 


\section{INTRODUCTION}

Before starting to investigate the biblical background of evangelism and before developing a model for congregational evangelistic campaigns, we must define what we mean by talking about congregational evangelistic campaigns. In German this type of campaign is usually called "Gemeinde-Evangelisation," that is, a campaign prepared and implemented by a local church. Two words in German correspond with the English "church," that is "Kirche" and "Gemeinde." The first term is usually used for the state churches, the second is the term preferred by the smaller denominations. This has nothing to do with the term "sect" ("Sekte"). Seventh-day Adventist churches in Germany are called "Adventgemeinden." The term "Gemeinde" could be translated as "congregation." With "Gemeinde" the idea of fellowship is emphasized more strongly than with "Kirche." In any case, "Gemeinde" stands for a local church--the entire congregation. I chose the term "congregational evangelistic campaigns" instead of "lay evangelistic campaigns" to stress the fact that not only a single person, namely a layman, is conducting a campaign, but that the lay congregation as a 
whole takes full responsibility for the campaign by using groups of laymen to prepare and implement the meetings.

Thus "congregational evangelistic campaigns" are defined as evangelistic campaigns prepared and implemented by the lay congregation, including the public proclamation by groups of laymen. "Traditional evangelistic campaigns" are defined in this paper as campaigns conducted by pastors or evangelists with or without the support of the local church. "Lay evangelistic campaigns" are campaigns conducted by lone laymen.

This paper first of all considers evangelism in the Bible and in history. The problem of reaching the unchurched both by laymen and by clergymen is addressed. From this survey, I draw conclusions that direct the focus of this study for congregational evangelistic campaigns.

The second chapter reports on previous congregational evangelistic campaigns in West Germany. This report is based on questionnaires sent to the pastors in West Germany and on interviews held with persons who have had some experience in this field. Because of the small number of returned questionnaires, the analysis provides only some trends. Nevertheless, the trends are important to perceive.

Chapter 3 presents a model for congregational 
3

evangelistic campaigns, and Chapter 4 contains conclusions and recommendations. 


\section{CHAPTER I \\ AN EXAMINATION OF THE IMPORTANCE OF CONGREGATIONAL EVANGELISTIC \\ CAMPAIGNS}

\section{The Importance of Evangelism in General}

Evangelism is Christ's commission to his church (Mark 16:15) and one of the reasons--if not the most important one--for the existence of the church. Christ does not want to save just a few individuals. The entire world must be reached by the evangel so that as many people as possible can participate in God's kingdom. M. S. Augsburger states:

Evangelism is the life of the church... Too often the church has failed to be evangelistic because it has been on the defensive rather than the offensive. The church has often been more concerned to prove itself right than to present the message which by its transforming effect is its own proof... Evangelism is letting people know and persuading them to accept the Gospel... Evangelism is the announcement of the kerygma.1

And C.E.Autrey says:

The work of evangelism is primarily the task of the church... Evangelism must always be vitally related to the church or it is not evangelism. Evangelism is an imperative for the local church. The

1 Myron S. Augsburger, Invitation to Discipleship: The Message of Evangelism (Scottdale, Pa: Herald Press, 1964), pp. 9-11. 
church which ceases to evangelize neglects one of its primary reasons for existing and begins the process of decline. 1

In order to fulfill this task Christ gave the Great Commission which is obviously addressed to all his followers. 2 But he also gave to his church spiritual gifts. One of them is the special gift of evangelism (Eph $4: 11)$.

\section{Linguistic Roots of 'Evangelism'}

In the old Testament and

in Palestinian Judaism

The Greek root of evangelism is euaggel-. This root is composed of two words: eu- "good" and aggel"announcement." The evangelist (euaggelistes) is the 'messenger of good news,' the person who proclaims good news. The septuagint (LXX) uses the same root as the NT. It is a translation of the Hebrew stem biśr.

1C. E. Autrey, Basic Evangelism (Grand Rapids: Zondervan Publishing House, 1959), p. 51. See idem, Evangelism in the Acts (Grand Rapids: Zondervan Publishing House, 1964), p. 18: "When the body of Christ is made sick for any reason, it ceases to be evangelistic. If a church does not multiply normally, it is sick." see R. T. Handy, Members one of Another (Valley Forge, Pa.: Judson Press, 1968), p. 91. Evangelism is not an appendix to the life of the church that one can choose freely. Evangelism is the heart-beat of the entire calling. See Robert E. Coleman, Des Meisters Plan der Evangelisation (Neuhausen-Stuttgart: Hänssler-Verlag, 1984), p. 72 .

2 Acts $8: 1-4$ points to the fact that apparently all the church members understood the Great Commission to be their task. 
The root bós occurs (1) in the noun beśrāh ("good news") six times, (2) in the verb biśśar ("to bring or proclaim good news") fifteen times, and (3) in the participles mebaśśser and mebaśśeret ("messenger of good news") nine times. 1 It is often used in the secular sense. The noun never has another meaning. However, there is also found a strong theological meaning in the verb and the participle: The good news is the message of Yahweh's salvation (Ps 96:2), righteousness (Ps 40:9), peace (Isa 52:7), and freedom (Isa 61:1). In the NT many of the OT verses in which bisr occurs are used in connection with the Messiah. 2

In post-biblical Judaism also the root bsr has theological meaning. The participle is especially

${ }^{1}$ There is some discussion whether bós means "good news" or only "news." Peter stuhlmacher, Das paulinische Evangelium - I.Vorgeschichte (Göttingen: Vandenhoek \& Ruprecht, 1968), pp. 111-112, pleads for the latter use, whereas Gerhard Friedrich, "Euaggelizomai," Theological Dictionary of the New Testament (TDNT), 10 vols., ed. Gerhard Kittel and Gerhard Friedrich (Grand Rapids: Wm. B. Eerdmans Publishing Company, 1982-83), 2:707; and 0. Schilling, "busr," Theological Dictionary of the old Testament (TDOT), 4 vols., rev. ed., ed. Johannes Botterweck and Helmer Ringgren (Grand Rapids: Wm. B. Eerdmans Publishing Company, 1977), 2:313 and passim, prefer the positive sense, because in all semitic languages the sense of joy is contained in the stem.

$2^{2}$ See Ps $40: 6-9$ in Heb $10: 5-10$; Isa $52: 7$ in Rom $10: 15-16 ;$ Acts $10: 36 ;$ Eph $2: 17 ; 6: 15$. Ps $68: 19$ is quoted in Eph 4:8-10; see Isa $60: 6$ in Matt $2: 11$; Isa $61: 1$ in Luke 4:18-19; Matt 11:5; Luke 7:22. Ps.68:11 talks about messengers of good news, Eph $4: 11$ about evangelists; compare Nah 2:1 in Acts 10:36. See Friedrich, "Euaggelizomai," pp. 709-710; Schilling, "ֵossr," p. 316. 
important and almost never occurs in a secular context. The messenger of joy, of good news, is an eschatological figure bringing about the new age and the good news of salvation. 1

In the LXX the noun beśrāh is translated with euaggelia and euaggelion. There is no theological meaning. Therefore, these two Greek words do not correspond with the NT euaggelion. Apart from three exceptions, euaggelizomai is always the translation of the verb and the participles with the stem bisr. It is also used in the theological sense. The Hebrew participles would normally correspond with euaggelos ("messenger of good news"), but the LXX never uses this term, probably because the euaggelos often had to be treated with a degree of suspicion. It prefers instead the participle euaggelizomenos. The LXX brings us nearer to the NT in connecting more often than is done in the Hebrew OT euaggelizomai and soteria, e.g., in Joel 2:32 and Isa $60: 6$, besides Ps $96: 2 .^{2}$

${ }^{1}$ See Isa $52: 7$ where the messenger of good news of peace is (a) God himself (Dt.Rabba 5,15), (b) the Messiah (Lev.Rabba 9.9; Midr.Tanh.twldwt, 14; Pirque Mashiach; Derech Eres Suta), (c) the eschatological prophet (11 $Q$ Melch.), (d) Elijah (Mids. Vajjosha; Pesikta Rabbathi 35), (e) a host of messengers (Midr. Tehillim on Ps 147:1); see also Stuhlmacher, pp. 122 and passim, 141, 147-152; and Friedrich, "Euaggelizomai," pp. 716-717.

${ }^{2}$ See Stuhlmacher, pp. 156, 159, 163; Friedrich, "Euaggelizomai," pp. 712-713, 722, and passim. 
To sum up: The stem busr in Hebrew means "good news" which is proclaimed. In theological context the messenger of good news proclaims God's righteousness, freedom, peace, and salvation. Especially in Isaiah there is an eschatological perspective pointing towards the NT. In Palestinian Judaism the messengers of this good news are particularly the Messiah and others. The LXX provides us with the root euaggel-, "proclaiming the good news" which becomes such an important term in the NT. Connecting good news with salvation even stronger than the Hebrew OT does, we are now still closer to the NT. The NT introduces Jesus as the messenger of the good news of salvation and as the personification and content of this good news, as evangelist and evangel. When the early Christians started to proclaim the Gospel of Jesus to the Gentiles and to use the bosr tradition, they were depending on the IXX and its use of the appropriate expressions for good news.

\section{In the New Testament}

The word family euaggel-

In the NT, mainly two important forms of the root euaggel- are used: the noun euaggelion and the verb euaggelizomai. Table 1 shows the usage of euaggel- in the NT : 
TABLE 1

USAGE OF euaggel- IN THE NEW TESTAMENT

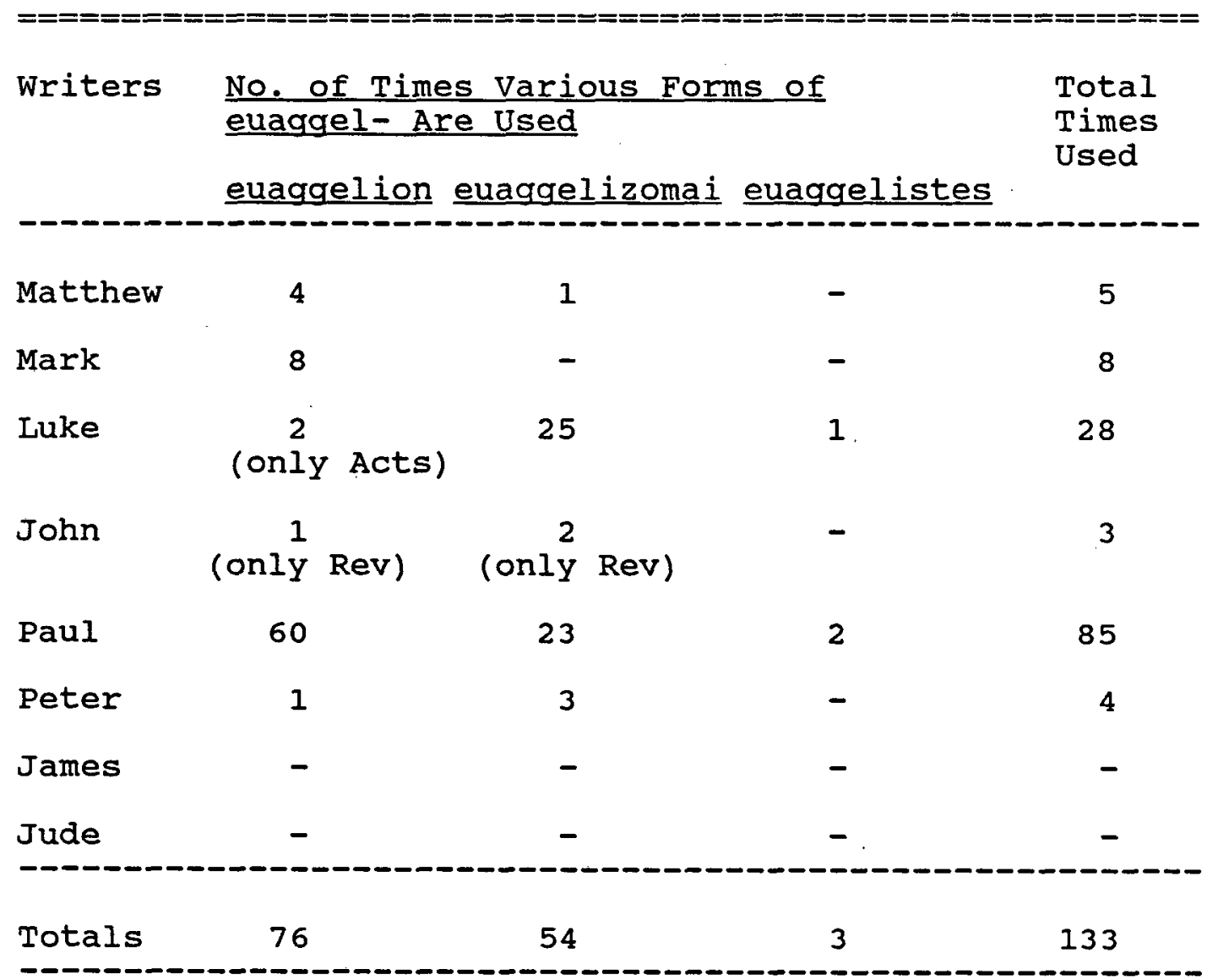

This list reveals some interesting facts:

1. Of the 133 instances where the root is euaggel-, 85 are used by Paul; euaggelion and euaggelizomai are distinct features of Pauline theology.

2. Second to Paul in using this root is Luke. However, euaggelion occurs only twice in Acts, whereas in the use of euaggelizomai, Luke slightly outnumbers Paul. The "evangelist" himself occurs only with Paul and Luke. 
3. Mark avoids the verb totally and favors the noun, quite the opposite of Luke.

4. John does not use either verb or noun in his gospel and in his epistles. Some scholars see the reason for this in a realized eschatology. 1 In any case, John prefers other terms. 2

The stem euaggel- in the NT is always a theological and never a secular term. With only one exception, $^{3}$ it always describes the content or preaching of the evangel, the good news of salvation in Jesus Christ. "If we were to sum up the content of the Gospel in a single word, it would be Jesus the christ." 4 The proclamation of euaggelion is ascribed to (1) Jesus (four times), (2) Paul (twenty times), (3) to Christians in general (eight times), (4) to Timothy (six times), (5) to Silvanus (four times), (6) to Peter (one time), and (7) probably to Euodia and syntyche (one time).

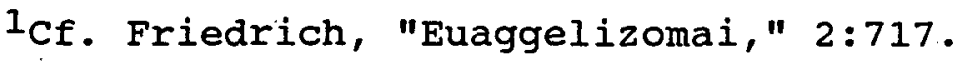

2 Martyreo ("to bear witness") occurs 76 times in the NT. John uses it 47 times: 33 times in the gospel, 10 times in the epistles, 4 times in Revelation. Martyria ("the bearing of witness") occurs 37 times in the NT. John uses it 30 times: 14. times in the gospel, 7 times in the epistles, 10 times in Revelation. See Hermann strathmann, "Martys," TDNT, 4:489.

31 Thess $3: 6$

${ }^{4}$ Friedrich, "Euaggelizomai," 2:731. 
Euaggelizesthai in the NT is done by (1) Jesus ${ }^{1}$ (seven times), (2) God (two times); (3) angels (two times), (4) John the Baptist (one time), (5) the Apostles (twenty-seven times), (6) other important persons (ten times), and (7) groups of persons (including usage in a general sense; eleven times). So the most important messengers of the evangel are: Jesus (seven times), Paul (twenty-four times), the other Apostles (three times), Barnabas (five times), Philip (three times), Timothy (two times). We certainly could call these persons "evangelists." Besides these more frequently mentioned messengers, we have persecuted Christians (Acts $8: 1,4$ ), men of Cyprus and Cyrene (Acts 11:20), and the first angel of Rev 14 proclaiming the gospel.

Sometimes euaggelion and euaggelizomai are even combined.2 In the case of Jesus, his entire work is described in terms of euaggelizesthai. 3 The same is true

$1_{\text {See }}$ P. C. Spicq, Saint paul - Les Épitres Pastorales (Paris: Librairie Lecoffre, J. Gabalda et Cie., 1947), p. 386. He talks about the evangelist and in writing "Hoc enim est nobile opus; quia ad hoc Christus est missus," he confirms that Jesus was an evangelist, too.

${ }^{2}$ See 1 Cor 9:18; 15:1; 2 Cor 11:7; Gal 1:11; Rev 14:6. Sometimes the verb is followed by the noun in the next verse or vice versa, e.g., Rom 1:15-16; 10:15-16; 15:19-20; Gal.1:7-9. It is hard to translate euaggelizesthai to euaggelion to point out the full impact of this expression, since euaggelizesthai already contains "good news". It would be something like "to evangelize the evangel."

${ }^{3}$ see Eph 2:17 and its context. 
of Paul (1 Cor 1:17). "Euaggelizomai is a missionary term - . But the message is also addressed to Christians (Rom 1:15, cf.11; 1 Cor 9:12-18; Gal 4:13; 2 Tim 4:5, cf.2). The same Gospel is proclaimed in both missionary and conǵregational preaching."1

synonyms

There are various kinds of synonyms to euaggel=. These are mainly the stems aggel- and keryk-. The following words of the word family aggel- may at least sometimes be synonymous with euaggel-: ${ }^{2}$ (1) aggelia ("message" - 1 John 1:5; 3:11), (2) aggello ("to proclaim a message" - John 20:18),3 (3) anaggello ("to proclaim" 1 Pet 1:12; 1 John 1:5), (4) apaggello ("to proclaim" Matt 11:4; 12:18); (5) diaggello ("to proclaim" - Luke 9:60), (6) exaggello ("to proclaim" - 1 Pet 2:9), (7) kataggel1o ("to proclaim" - 1 Cor 9:14).4 These synonyms

1Friedrich, "Euaggelizomai," 2:719.

2 Epaggel- and euaggel- are sometimes somewhat connected, cf. Acts 13:32-33; Rom 1:1-2; Eph 3:6; Heb 4:1-2; they are, however, not synonyms. Epaggello means "to promise." See Julius Schniewind and Gerhard Friedrich, "Epaggello," TDNT, 2:583.

3 "Resurrection and proclamation belong closely together, euaggelion and martys, martyrion." Julius Schiewind, "Aggelia," TDNT, 1:61. "Photius (MPG, 101, 989, 11-12) can still call Mary Magdalene an euaggelestria tes anastaeos" (ibid., p.61, n.2).

4 To euaggelion kataggellein. Prokataggello--Acts $3: 18 ; 7: 52--$ is only slightly similar to euaggeliozomai. Kataggeleus--Acts 17:18--is the messenger of foreign gods. 
underline the importance of the proclamation of the gospel.

The word family keryk- has three important words which should be mentioned: keryx ("preacher"), kerygma ("the preaching"), and kerysso ("to preach", "to proclaim"). All three terms are rather clearly synonymous with euaggel-: (1) Paul is the keryx of good news-$2 \operatorname{Tim} 1: 8,10,11 ;^{1}$ (2) the kerygma is the euaggeIion--Rom 16:25; 1Cor 15:14 as compared with 15:1-2; 1 Cor $1: 21 ; 2: 4$ as compared with $1: 17 ;^{2}$ and (3) kerysso is used together with euaggelion ${ }^{3}$ or with euaggelizomai. 4

Table 2 shows the NT usage of the root keryk- and reveals some interesting facts: (1) kerygma occurs rather seldom as compared with euaggelion which took the first

${ }^{1}$ The term seems to be synonymous with euaggelizomenos or euaggelistes. See Gerhard Friedrich, "keryx," TDNT, 3:696. Noah, however, is called keryx, too (2 Pet $2: 5)$.

2 See Friedrich, "keryx," 3:716. An exception is the kerygma of Jonah in Matt $12: 41$ and Luke 11:32.

${ }^{3}$ Matt 4:23; 9:35; 24:14; 16:13; Mark 13:10; 14:9: 16:15; 2 Cor 11:14; Gal 2:2; Col 1:23; 1 Thess 2:9. Indirect linkages are: Mark 16:20 with 16:15; 1 Cor 15:11-12 with 15:1; 2 Cor 4:5 with 4:3-4; Phil 1:15 with $1: 12,16$.

${ }^{4}$ Luke 4:18; 8:1; Rom 10:15. Indirect linkages are: Matt $11: 1$ and $11: 5 ;$ Luke $4: 44$ and $4: 43 ;$ Luke $9: 2$ and $9: 6 ;$ Acts $8: 5$ and $8: 12,35,40 ; 1$ Cor $1: 23$ and $1: 17$; 1 Cor $9: 27$ and $9: 16,18 ; 1$ Cor $15: 11-12$ and $15: 1-2$. There are some cases where kerysso refers to Moses (Acts 15:21) or the circumcision (Gal.5:11), etc. But we can agree with Friedrich, "Keryx," 3:711, that generally kerysso is a synonymon of euaggelizomai. Kerysso and euaggelistes are similar, too--2 Tim $4: 2$ as compared with 4:5. 
place in the other list. Matthew and Mark now also favor the verb instead of the noun; (2) Paul again uses the root the most often; (3) second to Paul is again Luke, who prefers the verb; and (4) John also avoids the use of this word family, the only reference is again found in Revelation.

TABLE 2

USAGE OF keryk- IN THE NEW TESTAMENT

\begin{tabular}{|c|c|c|c|c|}
\hline \multirow[t]{2}{*}{ Writers } & \multicolumn{3}{|c|}{$\begin{array}{l}\text { No. of Times Various Forms of keryk- } \\
\text { Are Used }\end{array}$} & \multirow{2}{*}{$\begin{array}{l}\text { Total } \\
\text { Times } \\
\text { Used }\end{array}$} \\
\hline & keryoma & kerysso & keryx & \\
\hline Matthew & 1 & 9 & - & 10 \\
\hline Mark & 1 & 14 & - & 15 \\
\hline Luke & $\begin{array}{c}1 \\
\text { (Gospel) }\end{array}$ & 17 & - & 18 \\
\hline John & - & ${ }^{1}$ (only Rev) & - & 1 \\
\hline Paul & 6 & 19 & 2 & 27 \\
\hline Peter & - & 1 & 1 & 2 \\
\hline James & - & - & - & - \\
\hline Jude & - & - & - & - \\
\hline Totals & 9 & 61 & 3 & 73 \\
\hline
\end{tabular}

G. Friedrich points out that euaggelizomai is also closely related to didasko (Acts 5:42; 15:35), laleo 
(Acts 8:25; 11:19-20), martyromai (Acts 8:25), and matheteuo (Acts 14:21).1 W. Bauer adds gnorizo. ${ }^{2}$

Summary

In the NT the good news is the good news of salvation in Jesus Christ. Jesus himself is proclaimer and content of the evangel. Salvation achieved by Christ's incarnation, life, death, and resurrection was foreshadowed in the OT, came about "when the time had fully come" (Gal 4:4), and is proclaimed from then until the end of historic time. This proclamation is the task of the present church, as it was the task of the early church following Christ's example as messenger and evangelist. The goal is to reach the entire world with the proclamation of the good news of salvation in Christ, and then Jesus Christ will come for the second time (Matt 24:14). The importance of the proclamation of the gospel is stressed by the frequent use of the stem euaggel-, its synonyms, and its related terms.

Thus, "evangelism" is an imperative for the church in these days. The Great Commission to preach the gospel to every creature is ours (Mark 16:15). This preaching of the gospel must be done both privately and

IFriedrich, "Euaggelizomai," 2:720.

2 Walter Bauer, Griechisch-Deutsches wörterbuch zu den Schriften des Neuen Testaments und der übrigen urchristlichen Literatur, 5th ed. (Berlin: Verlag Alfred Töpelmann, 1963), p. 629. 
publicly--as Jesus did. Congregational evangelistic campaigns seem to offer an important option to be considered as a method of the public proclamation of the evangel.

"Evangelist" in the New Testament

Although the term euaggelistes occurs only three times in the $\mathrm{NT},{ }^{1}$ the evangelist seems also to be the mebasser of the OT, the messenger of joy, and the euaggelizomenos of the LXX and the NT (Rom 10:15), 2 often even the person who proclaims the gospel (euaggelizomai). It is necessary to have this broader view, especially since the NT obviously tries to tell us that there were more evangelists than only Philip and Timothy. ${ }^{3}$ Even the keryx ( 2 Tim 1:10-11) seems to be an evangelist. 4

\section{A spiritual gift}

Although there are three lists of spiritual gifts in the NT--Rom 12; 1 Cor 12; and Eph 4--the term euaggelistes is only found in the latter one. Eph 4,1-6 talks about the importance of unity within the church. Vs. 7 mentions that "grace (charis) is given to each of us

$1_{\text {Eph }} 4: 11 ; 2$ Tim $4: 5 ;$ Acts $21: 8$.

${ }^{2}$ See Josef Ernst, Pleroma und Pleroma Christi (Regensburg: Verlag Friedrich Pustet, 1970), p. 182.

${ }^{3}$ see 2 cor $8: 18$; Phil $4: 3$; etc.

${ }^{4}$ See Friedrich, "Euaggelizomai," 2:719, who calls John the Baptist "evangelist". 
according to the measure of Christ's gift (doreas)". The Psalm quotation (vs. 8) and its interpretation (vss. 9-10) are stressing that Christ gave gifts to men. Vs. II mentions some of them. The context suggests that unity in the church can be enhanced by spiritual gifts. These gifts are to contribute to the growth of the "body" (vs. 15) and its maturity (vs. 13). They should be practiced in love (vs. 16).

The particles men and de, and the absence of the article in front of "teachers" point to four gifts in vs. 11: apostles, prophets, evangelists, and pastor-teachers. 1 In Ephesians apostles and prophets occur together and form the foundation of the church $(2: 20 ; 3: 5)$, resting themselves on the "cornerstone" Jesus Christ. They are obviously the leaders of the church with more than only a local sphere of influence

1see the structure of the Greek:

... tous men apostolous, tous de prophetas, tous de euaggelistas, tous de poimenas kai didaskalous.

Handly C. G. Moule, Ephesian Studies: Expository Readings on the Epistle of Saint Paul to the Ephesians (London: Hodder and Stoughton, 1900), p. 191, n.1, and Franz Mussner, Der Brief an die Epheser, ökumenischer Taschenbuchkommentar zum Neuen Testament, vol. 10 (Gütersloh: Gütersloher Verlagshaus Gerd Mohn, 1982) pp. 124-125, discern five gifts in Eph 4:11. Martin Dibelius, An die Kolosser, Epheser, an Philemon, Handbuch zum Neuen Testament (Tübingen: J. C. B. Mohr (Paul Siebeck), 1953), p. 81, however, speaks of "eine geschlossene Reihe" concerning apostles and prophets for which a "noli me tangere" is in operation. F. F. Bruce, The Epistle to the Ephesians (London: Pickering \& Inglis, 1961) p. 85, sees two pairs of gifts. 
and accountability. On the other hand, the evangelists and the pastor-teachers seem to carry mainly local responsibility. 1 Although the apostles and prophets in Ephesians ${ }^{2}$ may be the Twelve and at least partly NT prophets who did not exist any longer when the writing of the NT documents was finished, it is nevertheless difficult to discern in the gifts of apostleship, prophecy, and also evangelism--as some expositors perceive it--only gifts that have disappeared after the apostolic time, whereas the gift of pastor-teacher has remained a permanent one. 3

1Didran Y.Hadidian, "Tous de evangelistas in Eph. 4:11," Catholic Biblical Quarterly 28 (1966):317321, argues that the evangelists were gospel writers. This is rightly rejected by Paul Ewald, Die Briefe des Paulus an die Epheser, Kolosser und Philemon, 2nd ed. (Leipzig: A. Deichert'sche Verlagsbuchhandlung Nachf., 1910), since post-apostolic literature which understands 'evangelist' as gospel writer cannot be used to interpret apostolic literature.

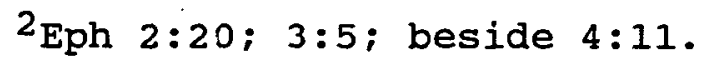

${ }^{3}$ See D. M. LLoyd-Jones, Christian Unity - An Exposition of Ephesians 4:1-16 (Grand Rapids: Baker Book House, 1981), pp. 192, 183, 193, and Heinrich Schlier, Der Brief an die Epheser (Düsseldorf: Patmos-Verlag, 1957), p. 196. For Norbert Hugede, L'Épitre aux Ephesiens (Geneva: Labor et Fides, 1973), p. 159, "les èvangèlistes sont les aides directs des apôtres." Charles J. Ellicott, $A$ Critical and Grammatical commentary on St. Paul's Epistle to the Ephesians with a Revised Translation, 2nd ed. (London: Parker and Son, 1859), p. 87 , sees them also as helpers of the apostles. Rudolf Bultmann, Theologie des Neuen Testaments (Tübingen: J. C. B. Monr (Paul Siebeck), 1953), pp. 452-453, however, says that the title "evangelist" was applied to missionaries as soon as the title "apostle" was reserved for the Twelve. The title "evangelist" became less and 
The context of $4: 11$ suggests that the gifts are necessary until the parousia of Christ, for the full maturity of the church $(4: 13)$ is only reached when the Lord will return. Until that moment the "equipping of the saints for the work of ministry," "the building up of the body of Christ," and the growth process (4:12, 13)-and therefore, the existence of all the gifts in 4:11-are needed. To divide 4:11 into temporary and permanent groups--one functioning only indirectly today, namely, in written form, whereas the other functions directly-seems to be artificial. 1 Furthermore these gifts are not confined to a special class within the church such as the clergy.

Since every believer is a priest, everyone is also endowed with spiritual gifts. ${ }^{2}$ But not everyone has

less important during the centuries of Christian church history.

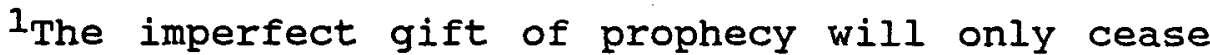
with the parousia of Christ, when full understanding is opened up (1 Cor. 13:8-10, 12). The warning against false prophets in the time before Christ's coming (Matt 24:14) implies the existence of genuine prophets, too. See also Joel 2:28-31. Paul's admonition to strive for charismata (1 Cor 12:31) includes apostleship, too (1 Cor 12:28-29), which therefore cannot be restricted to the Twelve.

2 See Karl Hermann Schelkle, "Christi Himmelfahrt," Geist und Leben 41 (1968):83. Franz Mussner, p. 124, says "daß Amt und Charisma ... nicht auseinanderfallen." Hans Conzelmann, "Der Brief an die Epheser," Der Brief an die Galater, Epheser, Philipper, Kolosser, Thessalonicher und Philemon, Das Neue Testament Deutsch, Göttinger Bibelwerk, ed. J.Becker, Hans Conzelmann, Gerhard Friedrich (Göttingen: Vandenhoeck \& Ruprecht, 1976), p. 109, perceives the gifts as church 
the same gifts; an evangelist is not an apostle. The two terms in Eph 4:11--apostolos and euaggelistes--are obviously not synonyms. Apostleship apparently includes evangelism--especially if we look at Peter and Paul--but the gift of evangelism seems not necessarily to include apostleship. The apostles are known for proclaiming the evangel (euaggelizomai), 1 but they are not merely evangelists. Apostles also seem to have received a special calling and not only a gifting which might not be true in the same way for evangelists. ${ }^{2}$

Evangelism is a spiritual gift which will doubtless be in the church until christ's return. Although apostles are also evangelists, the gift of evangelism is distinct from apostleship. Eph 4:11 contains four gifts coming in two pairs. Evangelism seems to have a smaller sphere of influence and responsibilities as compared with apostleship. obviously it is

offices, "durch welche die Heilsgaben allen Menschen vermittelt werden."

$28: 318$.

${ }^{1}$ see Friedrich, "Euaggelizomai," 2:737, Hadidian,

${ }^{2}$ See Mark 3:13-19; Luke 5,1-11; Acts 9:1-20. Apostolos is a person sent by another one. See apostello in Mark 3:14. Paul is apostolos Christou Iesou--2 Cor 1:1. He bears responsibility, but he also has authority. He speaks in the name of his Lord. See also Eduard Lohse, "Apostel," in Biblisch-Theologisches Handwörterbuch zur Lutherbibel und zu neueren übersetzungen, ed. Edo Osterloh und Hans Engelland, second ed. (Vandenhoeck \& Ruprecht, 1959), pp. 31-33. 
not a leadership function in the same sense that apostleship seems to be. Peter Wagner states:

The gift of apostle is the special ability that God gives to certain members of the Body of christ to assume and to exercise general leadership over a number of churches with extraordinary authority in spiritual matters which is spontaneously recognized and appreciated by those churches. Apostles often have the gifts of evangelist and teacher as well.1

\section{Timothy as evangelist}

The second text dealing with euaggelistes is 2 Tim 4:5. Timothy is admonished to be steady, to endure suffering, to do the work (ergon) of an evangelist, and to fulfill his ministry (diakonia). The basis for Timothy's ministry was his knowledge of the Holy Scripture and his faith in it which enabled him to have a faith relationship with Jesus Christ (2 Tim 3:14-17). This Scripture "equips the man of God for every good work (ergon)" (2 Tim 3:16-17). Timothy's ergon was the "work of an evangelist" (2 Tim 4:5). In 2 Tim 4:2, however, Timothy is already charged: "Preach the word" (keryxon ton logon), which is nothing else than "to do the work of an evangelist" (2. Tim 4:5).2 "The work of an

${ }^{1}$ c. Peter Wagner, on the crest of the wave: Becoming a World Christian (Ventura, California: Regal Books, 1983), p. 65

2 The statement in vs. 2 is only separated from the statement in vs. 5 by the insertion of the recipient's reaction to the message. See also the synonymous character of kerysso and euaggelizomai as mentioned above. 
evangelist" and "the fulfilling of his ministry" (2 Tim $4: 5)$ also seem to be synonymous.1 The rekindling of Timothy's gift in 2 Tim 1:6 might refer to the gift of evangelism (2 Tim 4:5).2 After thus calling Timothy again to perform the ministry of an evangelist, Paul gives the reason for his urgent call ( $2 \operatorname{Tim} 4: 6)$. He soon expects to die. Someone has to take the banner of truth and carry it on. Besides some allusions, Timothy is directly mentioned by name twenty-four times in the NT. This is the information we get: (1) There are prerequisites which he has or which he needs for his ministry (Acts 16:1-2; Phil 2:20-22; 2 Tim 3:14-15;4:5). (2) He is a co-worker with Paul (Acts 16:3; 17:14-15; 18:5; 20:4; Rom 16:21; 1 Thess $3: 6$ ). (3) He is "co-author" of Pauline letters (2 Cor 1:1; Phil 1:1; Col 1:1; 1 Thess 1:1; 2 Thess 1:1; Phlm 1). (4) He is a recipient of Pauline letters (1 Tim 1:2; 2 Tim 1:2). (5) He is a prisoner (Heb 13:23). (6) He

1 The diakonia tou logou in Acts $6: 4$ is the apostolic ministry of proclamation. See also Bernhard Weiss, Die Briefe an Timotheus und Titus - Kritischexegetischer Kommentar über das Neue Testament, 6th ed. (Göttingen: Vandenhoeck \& Ruprecht, 1902), p. 313; Gottfried Holtz, Die Pastoralbriefe, Theologischer Handkommentar zum Neuen Testament, 2nd ed. (Berlin: Evangelische Verlagsanstalt, 1972), p. 192; and Jürgen Roloff, Apostolat - Verkündigung - Kirche. Ursprung, Inhalt und Funktion des kirchlichen Apostelamtes nach Paulus, Lukas und den Pastoralbriefen (Gütersloh: Gütersloher Verlagshaus Gerd Mohn, 1965), p. 252.

2 see Weiss, p. 313. See also 2 Tim 4:11-16. Note also that even the enduring of suffering (kakopatheo in $4: 5$ ) is linked with the evangel in 1:8 (sygkakopadeo to euaggelio). 
proclaims the gospel. He is an evangelist. (1 Cor 4:17; 16:10; 2 Cor 1:19; Phil 2:19,22; 1 Thess $3: 2) .1$ (7) He is subordinate to Paul (Acts 19:22; Phil 2:19, 22; etc.). (8) He obviously has the gift of teaching (1 Tim $4: 6,11,13,16 ; 6: 2 ; 2 \operatorname{Tim} 2: 24 ; 4: 2) .{ }^{2}$ (9) His task is also exhortation ( $1 \operatorname{Tim} 4: 13 ; 6: 2 ; 2 \operatorname{Tim} 4: 2)$. (10) He is an apostle ( 1 Thess $2: 7-1: 1$ ).

Timothy's ministry is very similar to that of Paul--apostle, preacher, and teacher. ${ }^{3}$ Because of Timothy's close association with Paul as co-worker, as his representative and disciple, and because of his different gifts, Timothy takes a somewhat unique position. The gift of evangelism cannot be sorted out easily among his other gifts. In other words, he is not the best example for studying the gift of evangelism. We, therefore, have to take a look at Philip. Yet we know from Timothy's case that the gift of evangelism is manifested by the constant proclamation of the gospel. This gospel has to be preached "in season and out of season." The result may be suffering. This, however, must

$1_{\text {Timothy }}$ and euaggelion: 2 Cor $4: 3$ with $1: 1$; 1 Thess $1: 5 ; 2: 2,4,8-9$ with $1: 1 ; 2$ Thess $2: 14$ with 1:1. Timothy and euaggelizomai: perhaps Acts 16:10 with $10: 1-3 ; 2$ Cor 10:16 - 1:1.

2 See D. Edmond Hiebert, "Pauline Images of a Christian Leader," Bibliotheca Sacra 133 (1976):213-228.

${ }^{3}$ Paul's self-designations are found in 1 Tim 2:7; 2 Tim 1:10-11. He calls himself keryx which is a synonym of euaggelistes. 
not hinder the preaching. Presupposed for the ministry as an evangelist is a faith relationship with christ and total dependence on God's word. 1

\section{Philip as evangelist}

In Acts 21:8 Philip, one of the Seven (Acts 6), is called euaggelistes. The seven had certain leadership functions in the church and were not common deacons, 2 since the church was already very large. 3 . That they indeed had higher responsibilities is seen from Acts 6-8. Chap. 6 (second part) and chap. 7 report the story of Stephen. Chap. 8 deals with Philip. In Acts 21:8, Philip and his family are living in Caesarea, the capital of the Roman province, which was situated in Samaria. He is an evangelist, but nothing is said of his activity.

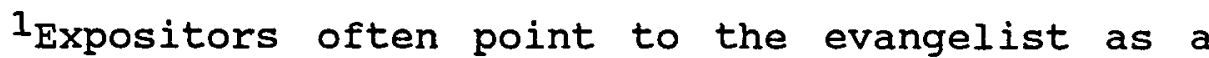
disciple of the apostle only. See Ernst, p. 183; Heinrich August Wilhelm Meyer, Handbuch über den Brief an die Epheser, 6 th ed. (Göttingen: Vandenhoeck \& Ruprecht's Verlag, 1886), p. 208, and Heinrich Schlier, Die Zeit der Kirche (Freiburg: Herder Verlag, 1956), pp. 138 and passim.

2see F. F. Bruce, Commentary on the Book of Acts,
The New International Commentary on the New Testament
(Grand Rapids: Wm. B. Eerdmans Publishing Company,
1954 ), p. 130. The noun diakonos as applied to the seven
is not found at all.

${ }^{3}$ Acts $4: 4$ mentions about five thousand men, without women and children. 
However, chap. 8 provides us with a report of Philip's evangelistic outreach.l In the respective sections, Philip is mentioned three times as proclaiming the good news (euaggelizomai). The person that evangelizes-Acts $8: 12,35,40--$ is later called an "evangelist." 2 so the gift of evangelism may not be restricted to the temn "evangelist," but a person that somewhat regularly proclaims the good news of salvation in Christ usually is doing the work of an evangelist. 3 Philip's evangelistic activity is also described with kerysso (8:5) and lego (8:6)--synonyms of euaggelizomai.

The content of the message is peri tes basileias tou theou kai tou onomatos Iesou Christou (8:12). As a result of his preaching, many people are baptized $(8: 12) .4$ In $8: 26,29$, Philip receives a kind of

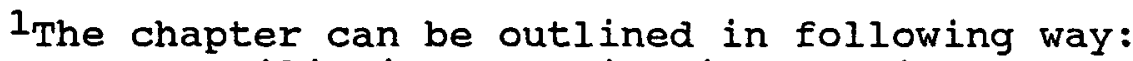

Chap. 8:5-13 - Philip is preaching in samaria.

Chap. 8:14-25 - The apostles are in Samaria.

Chap. 8:26-40 - Philip meets the Ethiopian.

2 See Helmut Merklein, Das kirchliche Amt nach dem dem Epheserbrief, Studien zum Alten und Neuen Testament, ed. Vinzenz Hamp and Josef Schmid (Munich: Kösel-Verlag, 1973), p.345; and Bruce, Commentary on the Book of Acts, p. 423. Gerhard Schneider, Die Apostelgeschichte II. Teil (Freiburg: Herder Verlag, 1982), p. 304, says: "Die Bezeichnung euaggelistes... ist im Anschluß an 8, 4f.35.40 im Sinne von 'Verkündiger des Evangeliums' $z u$ denken."

3 Euaggelizomai, in Acts $8: 12,40$, implies an ongoing action (present tense and past tense).

${ }^{4}$ In the case that Acts $8: 25$ refers to Philip, too, his evangelistic activity is called diamartyromai kai laleo ton logon tou kyriou and euaggelizomai. 
revelation and travels to the South, for Gaza is situated down in the costal plain. This was former Philistinian territory. So the evangelist is not restricted to just one city. He may travel around.

After the proclamation of the good news of salvation in Christ and after the baptism of the eunuch (8:35-39), Philip preaches in Azotus and moves northwards until he comes to Samaria and reaches Caesarea (8:40). In this city we find him and his family again more than twenty years later $(21: 8)^{1}$ In the case that Philip was not a Samaritan himself--as some scholars hold--then he even worked cross-culturally among those people. 2

p. 424 .

${ }^{1}$ See Bruce, commentary on the Book of Acts,

${ }^{2}$ See A. M. Johnson, "Philip the Evangelist and the Gospel of John," Abr-Nahrain, ed. J. Bowmann (Leiden: E. J. Brill, 1976), 16:49-72. The conversion of the Ethiopian eunuch was also cross-cultural evangelism. Today different types of evangelism are distinguished by E-1--the attempt to reach people of the same language and culture, E-2--the attempt to reach people of a similar language and culture, E-3--the attempt to reach people in a totally different culture; see John R. W. stott, Gesandt wie Christus - Grundfragen christlicher Mission und Evangelisation (Wuppertal: R. Brockhaus Verlag, 1976), p. 36, but the NT does not differentiate between them. Schneider, p. 304, takes Philip for the founder of the Christian church in Caesarea. Gottfried Schille, Die Apostelgeschichte des Lukas, Theologischer Handkommentar zum Neuen Testament (Berlin: Evangelische Verlagsanstalt, 1983), p. 409, rejects this view. 
Summary

The report on Philip as an evangelist helps to understand the gift of evangelism.

1. It seems that a person who regularly and systematically proclaims the gospel usually is an evangelist.

2. The proclamation of the gospel is primarily directed to unbelievers. 1

3. Evangelism requires courage and boldness. It also may cause suffering for the one who is preaching the message. 2

4. The content of the message is Jesus Christ (Acts $8: 5,12,35$ ) and the kingdom of God (Acts $8: 12$ ). 3

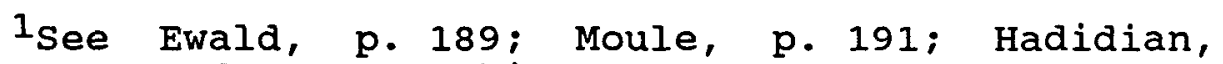
p. 317; and Theodor Zahn, Skizzen aus dem Leben der alten Kirche, 3rd ed. (Leipzig: A. Deichert'sche Verlagsbuchhandlung Nachf. (Georg Böhme), 1908), p. 87. But beside the missionary preaching there is also the congregational, for the euaggelion is given to both groups. See Col 1:5 (to euaggelion parestin); Phil 1:27; 2 cor 9:3. See Friedrich, "Euaggelizomai", pp. 734, 737.

2 See 2 Tim 4:5; Bruce, commentary on the Book of Acts, p. 117 .

${ }^{3}$ Content of the evangel: (1) Emphasis on God's initiative: (a) the gospel of God (Mark 1:14) and of Jesus Christ (Rom 15:19), of the glory of God (1 Tim $1: 11$ ) and of Christ (2 Cor 4:4), of the unsearchable riches of Christ (Eph $3: 8$ ); (b) the gospel of the kingdom of God ( Matt 24:14); (c) the gospel of the grace of God (Acts 20:24); (d) the gospel proclamation of the word of God (1 Pet 1:25). (2). Emphasis on the benefits for men: (a) the gospel proclamation of joy (Luke 2:10), (b) of the promise (Acts 13:32), (c) of faith (Gal 1:23), (d) the gospel of peace (Eph 6:15), (e) of salvation (Eph 1:13), (f) of hope (Col 1:23). (3) Definition and identification: (a) the truth of the gospel (Gal 2:5), 
It does not primarily deal with rules and doctrines, but calls persons into a relationship with a living savior and not into an acceptance of a mere philosophical or moral system. Evangelists are not necessarily eyewitnesses of the christ event. 1

5. Evangelistic activity brings certain results: joy (Acts $8: 7-8$ ), peace (Eph 6:15), hope (Col $1: 23$ ), and baptisms (Acts $8: 12-13,36-39$ ).

6. The evangelist may be an itinerant messenger of the kingdom of God (Acts 8:40), he also may be a local preacher of the gospel. 2

7. Evangelism includes cross-cultural proclamation of the good news. It may be pioneer work, too.

8. In Eph 4:11-12 evangelists like apostles, prophets, and pastor-teachers have to equip the church

(b) the mystery of the gospel (Eph 6:19). (4) Further characteristics as derived from text and context: (a) the gospel deals with the resurrecting of christ and the faithful ( 1 Cor 15); (b) the gospel aims at the conversion of man (Acts 14:15); (c) the gospel is a liberating force (Luke 4:18); (d) the gospel leads to the rest of God (Heb 4); (e) the gospel is concerned with man's reaction to God's love and his activity as creator (Rev 14:6-7); (f) the gospel has established one church (Eph $3: 6)$; (g) the gospel proclamation is often accompanied by signs and miracles (Matt 11:5). Most frequently the gospel is the gospel of Jesus Christ (about 16 times), of God (about 10 times), and of the kingdom of God ( 7 times).

${ }^{1}$ see Mussner, p. 125, and Schlier, Der Brief an die Epheser, p. 196.

${ }^{2}$ Philip may have stayed in caesarea for many years (Acts 8:40 and 21:8). 
members "for the work of ministry" (ergon diakonias-Eph.4:12) ${ }^{1}$. Although they labor for the conversion of unbelievers, their ministry is also directed towards the church. By means of their gift, unity (Eph 4:13.3-6) and maturity (Eph $4: 13-14$ ) of the church are promoted. The evangelist of Eph 4:11 apparently has a local leadership role. Equipping the saints for their ministry also includes euaggelizomai on the part of the church members. 2 J. M. Gray says:

"... for (pros) the equipment of the saints--
( 1 ) for ( $($ is $)$ work of ministry,
see Joachim Gnilka , building up of the body of Christ." scher Kommentar zum Neuen Testament (Freiburg: Herder Verlag, 1971), p. 213, but Schlier, Der Brief and die Epheser, pp. 198-199. Another possibility for reading this verse is: The equipment of the saints for the ministry serves the building up of the body. See Mussner, p. 127. See also "Evangelist," Seventh-day Adventist Bible Dictionary, rev.ed., ed. Siegfried Horn (Washington, D. C.: Review and Herald Publishing Association, 1979), p. 346 .

${ }^{2}$ What is the ergon diakonias? Diakonia is used 34 times in the NT. For further information, see Hermann Wolfgang Beyer, "Diakoneo", TDNT, 2:87-88. Diakonia is also used in connection with the proclamation of the gospel: Acts 6:4--the diakonia of the word; Acts 20:24-Paul's diakonia diamartyrasthai to euaggelion; Acts 21:19; Rom 11:13--Paul's diakonia among the Gentiles (compare diakonos in Eph $3: 6-8) ; 2$ Cor $4: 1$, (3, 5)-Paul's diakonia to preach the gospel; 2 cor 5:18--the diakonia of reconciliation with God; 2 cor 6:3--the diakonia includes the word of truth (vs. 7); 2 cor 11:8--the diakonia is euaggelion euaggelizomai (vs. 7); 1 Tim 1:12--Paul's diakonia is to be a preacher, apostle, teacher $(2: 7) ; 2$ Tim 4:5--Timothy has to do the ergon euaggelistou. This is his diakonia. So diakonia is not only the gift of helps; more often it is preaching the good news. The ergon diakonias in Eph 4:12 at least 
Though the noun evangelistes occurs in the NT only three times, the verb occurs frequently. Jesus Christ was an evangelist, for He preached the gospel (Luke 20:1); Paul was an evangelist as well as an apostle (Rom 1:15); Philip the deacon was also an evangelist (Acts 21:8), as was Timothy the pastor (2 Tim 4:5), and indeed all the early disciples who, upon being driven out of Jerusalem, "went about preaching the word" (Acts 8:4). But Eph 4:11 teaches that one particular order of the ministry, distinguished from every other, is singled out distinctly by the Head of the church for this work. All may possess the gift of an evangelist in a measure and be obligated to exercise its privilege and duty, but some are specially endued with it...1

9. The evangelist can be male (Acts 21:8) or

female (Phil 4:2-3). There is also no distinction like

layman and clergyman.

10. The gift of evangelism is not restricted to the time of early Christianity. Evangelists are especially needed in the time of the end, for "this gospel of the kingdom will be preached throughout the whole world, as a testimony to all nations; and then the end will come" (Matt 24:14). The methods of proclamation are not explicitly discussed in the NT. They may change with time, culture, and location, as seen in the case of Paul.2 Nevertheless, evangelism must always be the

includes the proclamation of the gospel. The evangelists of Eph 4:11 equip others to perform their ministry of evangelism.

IJ. M. Gray, "Evangelist," The International Standard Bible Encyclopedia, ed. Geoffrey W. Bromiley (Grand Rapids: Wm. B. Eerdmans Publishing Company, 1962), $2: 204$.

${ }^{2}$ see his proclamation in Athens (Acts 17) as compared with his work in corinth ( 1 Cor 2). 
heartbeat of the church. The church does not exist for itself. It has a mission, and this mission is the proclamation of the gospel. Although methods may vary evangelism must be both personal evangelism and public evangelism. Both ways of preaching the evangel have their place in the mission of the church, and they are complementary. Jesus and the apostles are the church's example. ${ }^{1}$ The SDA churches of West Germany do not fulfill Christ's commission when they restrict their mission to personal evangelism. Public campaigns must be conducted. ${ }^{2}$

\section{Evangelism in Church History}

The Apostolic Time

The Apostolic period is the major portion of the time of the NT. Evangelism was the heartbeat of the early church. Many persons and entire groups of believers were found proclaiming the gospel. An amazing expansion of Christianity took place in the first century.

Christianity began in little obscure Palestine and within three decades spread to Rome. The reason for its unparalleled growth lay in its spirit and methods. Its spirit and methods were thoroughly evangelistic. ${ }^{3}$

${ }^{1}$ see, for example, Luke $8: 1-21$ as compared with Luke 19:1-10; John 6 and 7 as compared with John 3 and 4; and Acts 2 as compared with Acts 10. See also Acts 20:20. $8: 5-8,12$.

${ }^{2}$ see Philip's proclamation in Samaria--Acts

${ }^{3}$ Autrey, Evangelism in the Acts, p. 15. 
The history of the New Testament churches verifies the truth that they were aggressively evangelistic. The church at Antioch under the direction of Barnabas and saul prosecuted an intensive effort to evangelize the entire area around it (Acts 11:26). They were not satisfied with winning and teaching hundreds within reach of the local church, but they laid their hands on Barnabas and saul and sent them out to Asia Minor to evangelize in many other places (Acts 13:1-3). This evangelistic program . . was totally free from selfishness. They gave up their two best leaders for the missionary task. 1

The first centuries $A$. D.

The term "evangelist" did not have much importance in the early Christian literature.

- . it disappears entirely in the immediately postapostolic literature, it is not found in the Apostolic fathers nor in the Didache. When it reappears, as in Tertullian, De Praescriptione 4 (Qui pseudapostoli hisi adulteri evangelizatores) and in Eusebius (Hist. Eccl. III. xxxvii, 2, 4) it is used to describe such men as were called 'apostles' in the Didache. On the other hand the apostles are described as "entrusted with the evangel" ( 1 cllement, 42); as the evangelizers (Barnabas, viii, 3).2

In his Adversus Praxean 21. 23, Tertullian calls the author of a gospel "evangelist".3 Eusebius writes:

Very many of the disciples of that age (pupils of the apostles), whose heart had been ravished by the divine word with a burning love for philosophy (i.e., asceticism), had first fulfilled the command of the Saviour and divided their goods among the needy. Then they set out on long journeys, performing the office of evangelists, eagerly striving to preach christ to

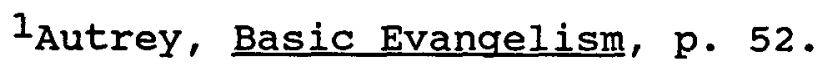

2 Hadidian, $28: 318$.

3 Merklein, p. 247 . 
those who as yet had never heard the word of faith, and to deliver to them the holy gospels. 1

So after a period of silence, evangelists in the

early church are (1) apostles, (2) successors of the apostles, and (3). gospel writers. 2 Christianity still was expanding, finally to become the state church.

Middle Ages, Reformation, and Pietism

When Christianity had become the official religion of the Roman Empire, the Barbarian tribes were Christianized. During the Middle Ages the Celtic "church" and the Benedictines established mission compounds all over Europe. There were traveling evangelists like Colomban and Boniface. Unfortunately, pagan customs were also mixed up in the various forms of Christianity. Later on the Vikings became Christians. Innocent III has the distinction of being the Pope who authorized the first of a whole new series of missions-the Friars. 3 However, there were also persons like

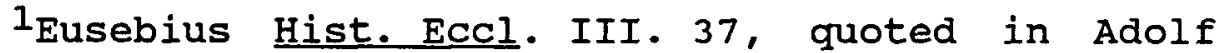
Harnack, The Mission and Expansion of Christianity in the First Three Centuries, 2 nd ed. (London: Williams and Norgate, 1968), 1:348.

2see Ernst, p. 181, and Friedrich, "Euaggeli-
zomai," $2: 737$.

${ }^{3}$ see Ralph D. Winter, "The Kingdom strikes Back: The Ten Epochs of Redemptive History," in Perspectives on the World Christian Movement, pp. 142-150, ed. Ralph D. Winter and Steven C. Hawthorne (Passadena: William Carey Library, 1983). 
P. Waldo and J. Wicliff whom we may call evangelists. The Waldenses were a lay movement, proclaiming the gospel and stressing the importance of the Bible. They also served as itinerant preachers. 1 such movements were not content with the spiritual condition of the church and its doctrines. The gospel was adulterated. God's word was withheld from the people and was overgrown with traditions and ecclesiastical laws. The clergy was the church. The Reformation came and the Reformers as evangelists ${ }^{2}$ proclaimed salvation by Jesus Christ alone instead of justification by works. They proclaimed the priesthood of all believers instead of the priesthood of a special class.

After the Reformation, Protestantism soon lost its power and grew stiff in orthodoxy. A new movement arose within the protestant church--Pietism. Important

${ }^{1}$ See P.Rahlenbeck, "Evangelisation," Realencyklopädie für protestantische Theologie und kirche, 3rd ed., ed. Albert Hauck (Leipzig: J. C. Hinrich'se Buchhandlung, 1898), 5:661.

${ }^{2}$ Luther wrote (WA XII 259): "Evangelium aber heysset nichts anders, denn ein predig und geschrey von der genad und barmhertzikeitt Gottis, durch den herren Christum mit seynem todt verdienet und erworben. Und ist eygentlich nicht das, das ynn büchern stehet und ynn buchstaben verfasset wirtt, sondern mehr eyn mundliche predig und lebendig wortt, und ein stym, die da ynn die gantz welt erschallet und offentlich wirt ausgeschryen, das mans uberal höret." quoted by W. Schmauch, "Evangelium," Evangelisches Kirchenlexikon - Kirchlichtheologisches Wörterbuch, 2nd ed;, ed. Heinz Brunotte and otto Weber (Göttingen: Vandenhoeck \& Ruprecht, 1961), $1: 1216$. 
representatives were Spener, Francke; and zinzendorf. 1 The Moravians were an especially strong evangelistic movement.

Modern times and the 20th century

Out of Pietism the revival movements grew. In England, George Whitefield was involved in evangelistic outreach. John Wesley was an evangelist who made a great impact. His movement became the Methodists. In the United States of America frontier evangelism was developed and great revival movements occurred. Important evangelists were C. Finney, a lawyer who died in 1875, and Dwight Moody, a salesman who died in 1899. Today there are professional evangelists; perhaps the most well-known is Billy Graham.

In Germany and in German-speaking countries societies were founded for evangelistic outreach; i.e., in 1840, the Pilgermission Chrischona near Basel; in 1848, the Evangelistische Gesellschaft für Deutschland; in 1886, the Johanneum, a school for evangelists; in 1888, the Gnadauer Verband; and in 1918, the

Isee Rahlenbeck, "Evangelisation," 5:663 and H. Rendtorff, "Evangelisation und Volksmission," Religion in Geschichte und Gegenwart - Handwörterbuch für Theologie und Religionswissenschaft, 3rd ed., ed. Kurt Galling (Tübingen: J. C. B. Mohr (Paul Siebeck), 1958), $2: 771$. 
Volksmission. 1 Responsible for the Volksmission are the church and each faithful Christian. Already in 1884, Prof. D. Christlieb called for evangelism by lay evangelists, but there were also some important professional evangelists; i.e., E. Schrenck (1831-1913), S. Keller (1856-1924), and E. Modersohn (1870-1948).2

At the end of the nineteenth century, P. Rahlenbeck defined evangelism for the Protestant church as (1) proclamation of the pure word of grace in areas which were not reached by the Reformation, and (2) proclamation not performed by the ecclesiastical institution. 3 Today this definition is replaced by more ecumenical ones. Characteristic of the "New Evangelism" in Germany are the Evangelical Academies, the German Evangelical Kirchentag, Factory Evangelism, evangelism through the mass media, and the church speaking to current affairs. 4

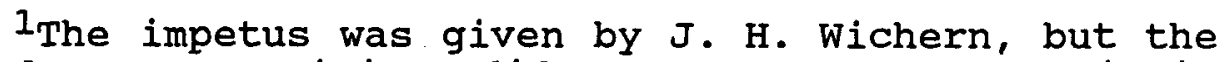
so-called Innere Mision did not pursue evangelistic activities. A second effort by G. Hilbert in 1916 led to the foundation of the Volksmission.

${ }^{2}$ see H. Haarbeck, "Evangelisation," Evangelisches Kirchenlexikon - Kirchlich-theologisches Handwörterbuch, 2nd ed., ed. Heinz Brunotte and otto Weber, (Göttingen: Vandenhoeck \& Ruprecht, 1961), 1:1188-1189; Rahlenbeck "Evangelisation," 5:664-665; and Rendtorff, "Evangelisation und Volksmission," 2:771-773.

$$
{ }^{3} \text { Rahlenbeck, "Evangelisation," 5:661-662. }
$$

${ }^{4}$ see H. H. Ulrich, Evangelism in Germany: An Ecumenical Survey, published for the World Council of churches by the United society for Christian Literature, 
The ecumenical movement is very much interested in evangelism. The main emphasis is on evangelism as the task of the entire church. The priesthood of all believers is stressed. The role of the laity is much discussed. And evangelism is seen not simply as proclamation but as the entire ministry of the church. However, in 1976 stott said that after Bangkok the World Council of Churches lost its enthusiasm for the missionary task of the church. I Yet strong denominational and interdenominational groups still promote evangelism in the twentieth century. Part of the Lausanne covenant says: "We need to break out of our ecclesiastical ghettos and permeate non-Christian society . . World evangelization requires the whole church to take the whole Gospel to the whole world." 2

The concept of evangelism has become rather broad today and includes the social gospel and the theology of liberation. Hao stresses the proclamation of the gospel by acts. 3 certainly, words and deeds have to go together,

World Evangelism Today Series (London: Lutterworth Press, 1958), pp. 21-25.

Istott, p. 35 .

${ }^{2}$ Quoted in James F. Engel, Contemporary Christian Communications: Its Theory and Practice (Nashville: Thomas Nelson Publishers, 1979), p. 65.

${ }^{3}$ Yap Kim Hao, "Reden mitten unter dem Tun," in Evangelisation im ökumenischen Gespräch - Beiträge eines Symposiums (Genf 1973), ed. Walter Arnold (Erlangen: Verlag der evangelisch-lutherischen Mission, 1974), 
but it is preferable to call the proclamation evangelism, and the acts something like charity or social action. Both are necessary, but the Bible uses separate terms and doubtless so should we. 1

Throughout the history of the church there was at least a little interest in evangelism. Often lay people were engaged in this task. In our days evangelism has been rediscovered. It is emphasized again and again. But still, much can be improved--including the status of evangelism in the SDA church in west Germany.

pp. 77, 84, says: "Wir haben oft Evangelisation nur mit der Weitergabe des Evangeliums in worten gleichgesetzt... Es ist heute notwendig, das Evangelium durch Taten $z u$ verkündigen... Worte und Taten sind lebensnotwendig für die Verkündigung und gehören unauflöslich zusammen. Worte überzeugen nicht, wenn sie nicht auf Taten beruhen. Taten sind bedeutungsios, wenn sie nicht mit den Worten des Evangeliums in Beziehung stehen. Worte und Taten müssen ineinander verwoben werden... Mehr als Wort und Tat oder Wort, das die Tat nach sich zieht, ist wahre Verkündigung Wort-in-der-Tat, Reden mitten unter dem Tun, lebendig gewordenes Zeugnis... Verkündigung des Evangeliums für die Menschen in ihrer heutigen situation verlangt 'Wort in Taten' und 'Taten im Wort'." See also Claude Geffré, "Theological Reflections on a New Age of Mission," International Review of Mission 71 (1982): 478-492, and William J. Richardson, Social Action versus Evangelism: An Essay on the Contemporary Crisis (South Pasadena: William Carey Library, 1977), pp. 26-39.

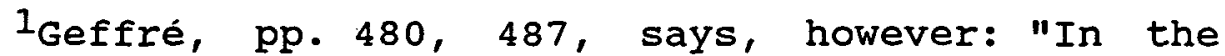
present situation of the world it is impossible, within the Church's mission, to dissociate evangelization from all those tasks that serve human liberation and promotion - . there is not much sense . . . in trying to maintain at all costs the old dichotomies between 'evangelization' and 'action'." Handy, pp. 91-92, seems to take a well-balanced stand. 
E. G. White and

evangelism

E. G. White as a Christian writer of the nineteenth and twentieth century was very much interested in evangelism. Her view touched on (1) those she called evangelists; (2) the character of the work; and (3) the content of the message.

1. Evangelists, according to White, include: (a) Jesus Christ, 1 (b) Timothy, ${ }^{2}$ (c) evangelists in the modern understanding (that is persons like Billy Graham), 3 (d) Christian colporteurs, 4 (e) medical missionaries including nurses and physicians ${ }^{5}$ (f) parents, 6 (g) Christian ladies, 7 (h) persons that give Bible

1Ellen G. White, The Ministry of Healing (Mountain View: Pacific Press Publishing Association, 1942), p. 22 .

2 Idem, Evangelism (Washington, D. C.: Review and Herald Publishing Association, 1970), p. 337.

IIbid., p. 116 .

${ }^{4}$ Idem, Colporteur Ministry (Mountain view: Pacific Press Publishing Association, 1953), pp. 23, 39 .

5Idem, Evangelism, p. 520; idem, counsels to Teachers, Parents, and students Regarding Christian Education (Mountain View: Pacific Press Publishing Association, 1970), p. 471, idem, Counsels on Health and Instruction to Medical Missionary Workers (Mountain View: Pacific Press Publishing Association, 1941), pp. 544, 546 .

6Idem, counsels to Teachers, Parents, and Students Regarding Christian Education, p. 157.

7Idem, Testimonies for the Church, 9 vols. (Mountain View: Pacific Press Publishing Association, 1948), 6:118. 
studies, $^{1}$ (i) evangelistic companies, 2 and (j) the youth. 3

2. The character of the work, according to White, is: (a) proclamation of the gospel combined with the care for health, 4 (b) teaching, 5 (c) personal work, 6 (d) watering and cultivating the sown seed, 7 (e) working from house to house and in highways and byways, 8 (f) building up the churches in faith, 9 and $(g)$ of more importance than the work of a minister. 10 white also stressed that (h) the evangelist is a lover of souls, who hunts and fishes for men, 11 and that (i) like Timothy, the evangelist is not settled over one church only. 12

${ }^{1}$ Idem, Evangelism, p. 441 .

${ }^{2}$ Ibid., p. 96 .

${ }^{3}$ Ibid. , pp. 23-24.

${ }^{4}$ Ibid., p. 520; idem, Testimonies, 6:118.

${ }^{5}$ Idem, Evangelism, p. 520 .

${ }^{6}$ Idem, Testimonies, $6: 118$.

${ }^{7}$ Idem, Evangelism, p. 337 .

8Idem, Counsels to Teachers, Parents, and Students Regarding Christian Education, p. 471; idem, Counsels on Health and Instruction to Medical Missionary Workers, p. 318 .

${ }^{9}$ Idem, Evangelism, p. 337.

${ }^{10}$ Ibid.

${ }^{11}$ Ibid., p.116.

12 Ibid., p. 337. 
3. Content of the message embraces: (a) Jesus Christ, 1 (b) not only doctrines, 2 (c) the call to follow Jesus, 3 (d) the word of God and prophecy, 4 and (e) the third angel's message. 5

E. G. White seems to have a broad view concerning the persons who are called "evangelists." Obviously she thinks of both local evangelists and those being responsible for a wider area, of resident ones and itinerant ones. Even parents can be evangelists, in her opinion. She also stresses the importance of medical care in connection with the proclaiming of the gospel. Special emphasis is laid on church members performing evangelistic service. 6 All this calls to mind the biblical data and gives an additional stimulus for evangelistic activities and campaigns in these days.

\section{Implications}

Evangelism is a gracious gift of God. When the gospel is proclaimed, men can come to know their Redeemer. They can now repent and can accept Jesus as their

${ }^{1}$ Ibid., pp. 184 and passim.

2 Ibid., pp. 163-164.

${ }^{3}$ Idem, Testimonies, $6: 118$.

${ }^{4}$ Idem, Evangelism, p. 337 .

${ }^{5}$ Ibid., p. 184 .

${ }^{6}$ Ibid., pp. 351-357; idem, Ministry of Healing, pp. 148-149. 
Savior and Lord. They can be baptized and thus be added to the family of God. The ministry of evangelism is of vital importance:

How, then, can they call on the one they have not believed in? And how can they believe in the one whom they have not heard? And how can they hear without someone preaching to them? And how can they preach unless they are sent? As it is written, "How beautiful are the feet of those who bring good news!" (Rom $10: 14-15)^{1}$

Especially at the end of time, proclamation of the gospel is important: (1) God does not want anyone to perish (2 Pet $3: 9$ ); (2) errors become more and more widespread (2 Tim 4:3-4; Matt 24:23-26); (3) it is God's commission to his church to reach the unreached multitudes with the gospel (Mark 16:15; Matt 24:14). But evangelism is not only beneficial for the recipients of the message. The evangelist himself is blessed and is drawn nearer to his Lord when he bears witness of him (Matt 10:32; Luke 6:38). Finally, the gift of evangelism is needed for the church and its outreach. For the equipping of the saints (1) for the work of ministry and (2) the building up of the body, the evangelist is essential (Eph 4:11-12).

Taking a look at world mission, one realizes that the world is not yet reached by the gospel, although there is much interest in evangelism today. According to Ralph D. Winter, there are more than two billion

${ }^{1}$ Bible quotations are taken from the New International Version. 
people who have never heard about christ and another billion within the direct reach of christianity who have not taken a decision for Christ and who probably have not heard very much about him either. Winter says 6,550 people groups are more or less "reached" by the gospel, and 16,750 groups are not. 1 The population of West Germany is more than 60 million, yet only about 25,000 are Seventh-day Adventists. Only a rather insignificant percentage of the total population attends church regularly. Society is almost totally secularized. Besides the secular man, there are tens of thousands of Moslems in West Germany who need to be reached for Christ. What a tremendous challenge for the church! Yet only a few individuals are involved in proclaiming the gospel.

When Jesus gave his commission to the church, he must have given along with it the possibility to fulfill the appointed task. It was no doubt for this reason that he bestowed on his church different spiritual gifts. It seems undeniable that the only chance to complete the task is to use the entire church's full potential and to prepare the way for another outpouring of the Holy spirit. Certainly an enormous reservoir of gifts exists within the church. It seems a must to detect this

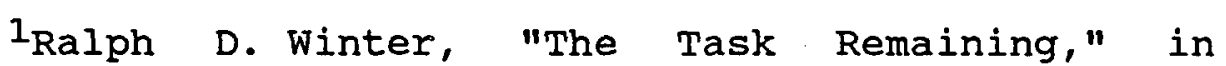
Perspectives on the World Christian Movement, ed. Ralph D. Winter and Steven C. Hawthorne (Pasadena: William Carey Library, 1983), p. 324 . 
potential and to use it. The evangelists in the congregations must be discovered, supported, encouraged, and educated for their ministry. The church cannot afford to have only one person working where ten could be available. It cannot afford to have an actor-spectator structure. It cannot afford to have a dichotomy between pastor and church member, with the "clergy" paying only lip-service to the doctrine of the priesthood of all believers and the "laymen" refusing to take any responsibility. I Church members are not merely "assistant evangelists"--members may have the gift of evangelism and the pastor may not. Why should a "layman" not preach an evangelistic sermon? Why are laymen so commonly restricted to ushers and hostesses? Some might preach an even better sermon than does the professional evangelist. People should not be overloaded, but surely they should be able to use their full potential without their pastors getting angry, irritated, or jealous!

\section{Evangelistic methods}

A brief word on methods is noted here, but no list of different types of evangelistic outreach is specified. ${ }^{2}$ Different times and different situations 1 The next section deals with this topic more
extensively.
${ }^{2}$ Such a list is, for example, found with Burtt
Potter, The Church Reaching out (Durham, North Carolina:
Moore Publishing Company, 1976). See also Richard 
require different methods. One has to be adaptable and inventive. Some general principles in an endeavor to reach the unreached include: (1) face-to-face encounter with the recipient, (2) a non-threatening approach, (3) a person-centered message, (4) proximity, (5) simplicity, (6) prayer, and (7) unity with co-workers in diversity. Receiving the gift of evangelism does not mean that no further learning process is necessary. The evangelist can increase in skillfulness and fruitfulness. 1 Therefore, he must carefully think about the message he proclaims. He must carefully choose the best method to reach the unbeliever. The most important principle is love. ${ }^{2}$ Love touches the heart of the unbeliever. Love makes it easier to carry out the tough ministry of evangelism. Love is to be the decisive factor that promotes unity and growth of the church and equips the saints for the work of ministry.

A. Jackson, "A New Testament Pattern for a Ministry of Evangelism," Southwestern Journal of Theology 17 (1975): $32-34$.

$1_{\text {see }}$ Matt 25:14-30.

${ }^{2}$ See Eph 4:16; 1 Cor 13). See Theron Chastain, we Can Win others: A Programm of Evangelism for PresentDay Churches (Philadelphia: Judson Press, 1953), p. 57. 
Laity versus clergy in Reaching the Unchurched

Definitions

Laity and clergy

In talking about ministers and laymen, one usually has in mind two distinct and separate classes, the clergy and the laity. The common understanding is that the church is made up of these two classes; but more properly, "the two words kleros (clergy) and laos (laity) - . denote the same people, not different peoples."I The entire church is kleros, and the entire church is laos, ${ }^{2}$ all are priests ${ }^{3}$ with only one high

${ }^{1}$ William Robinson, Completing the Reformation: The Doctrine of the Priesthood of All Believers (Lexington: College of the Bible, 1.955), p. 17.

${ }^{2}$ Kleros means "lot" (Matt 27:35; Acts 1:26); "place" (Acts 26:18); "inheritance" (Col 1:12); "charge" ( I Pet 5:3; Luther's translation says even "churches"). Laity may be derived from laos which is often opposed to ta ethne (the people of God as distinct from the Gentiles, see 2 cor $6: 16)$.

${ }^{3}$ Usually the priesthood of all believers is proved with 1 pet 2:9. But the context is not dealing with priesthood, it deals with election and holiness. An outline of 1 Pet may look like this:

The church, its groups, and Jesus-holy conduct and sufferings (2:11-4:11)

Election and holiness

$(1: 2-2: 10)$

Introduction $(1: 1-2)$
The church and

its groups--holy

conduct and suffer-

ing $(4: 12-5: 9)$

Election and holiness

(5:10-12)

Conclusion $(5: 10-13)$

The first election-and-holiness section is subdivided into (1) election $(1: 3-12)$, and (2) holiness (1:13-2:10) -- (a) the call to holiness $(1: 13-21)$, (b) the call to love the brethren $(1: 22-25)$, and (c) the call to growth $(2: 1-10)$. Within this section 1 Pet $2: 9$ is found. Even 
priest, namely Jesus Christ. ${ }^{1}$ Although we find in the primitive church ordained persons and non-ordained persons, although the church members have different gifts--even the gift of leadership, they all together form the laos, the body of christ. All the believers proclaim the gospel. They all are the household of adults, as Robinson stressed it, and one does not have to deal with them as if they were children. 2 ". . the

the OT texts from which 1 pet $2: 9$ is taken stress election and holiness and not priesthood (Exod 19:5-6; Isa 43:20-21). John Hall Elliott, The Elect and the Holy. An Exegetical Examination of 1 Pet $2: 4-10$ and the Phrase basileion hierateuma (Leiden: E. J. Brill, 1966), p. 211 and passim, leaves no room for the priesthood of believers in 1 Pet $2: 9$. He notes: (1) There is no relation to a Levitical conception of priesthood and no polemics against the Jewish cult; (2) no connection is made between Christ's priesthood and hierateuma; (3) there is only a one-way mediation in witnessing to the world and no two-way mediation; (4) the attributes are applicable only to the corporate body of priests, not to the individual; (5) nothing is said of baptism as ordination to priesthood; and (6) the text does not present a theory on priesthood but serves the motifs of election and holiness. Although Elliott's contribution is widely acknowledged, some scholars say he might have gone a little too far. See Pierre Sandevoir, "Un Royaume de Prêtres?" Études sur la Première Lettre de Pierre, Congrès de l'ACFEB, Paris 1979, presentation by Charles Perrot, Lectio Divina 102 (Paris: Les Éditions du Cerf, 1980), p. 227; R. Schnackenburg, "Umschau und Kritik," Biblische Zeitschrift 12 (1968):152-153. Beside the dominant motif, priesthood plays a role, too (see 2:5). However, there are allusions to the priesthood of all believers in other NT texts: Rev 1:6; 5:9-10; 20:6; Heb 4:16; 10:14, 22; 13:10, 15-16; Rom 12:1; Phil 2:17, $4: 18 ; 2 \operatorname{Tim} 4: 6$.

$$
\begin{aligned}
& { }^{1} \text { See Heb } 4: 14-5: 10 ; 7: 1-8: 2 ; 9 \text { and } 10 . \\
& { }^{2} \text { See Robinson, p. } 64 .
\end{aligned}
$$


right and dignity of the priesthood remains in communi says Luther--with the people."1

In church history the words cleros and laos soon were used to denote two separate entities within the people of God. Kleros was used for the ordained ministers. Laos described the common believers. Clement of Rome, as early as the end of the first century A. D., made this kind of distinction. 2 when the development of the two separate classes went on, the laity sometimes were not even called church. The hierarchy became the real church. The laity was a weaker partner who suffered from discrimination. 3 From the middle of the third century, three groups existed within the church: lay people, clerics, and monks.

The lay condition is presented as a concession to human weakness . . the laity, concerned in temporal affairs, have no part in the sphere of sacred things. Duo genera Christianorum. 4

During the seventeenth century "the privilege of evangelizing the newly-discovered lands becomes the exclusive

${ }^{1}$ Carlyle Marney, priests to Each other (Valley Forge: Judson Press, 1974), p. 12.

${ }^{2}$ see Yves M. J. Congar, Lay People in the Church (Westminster: Newman Press, 1970), p. 4; M. E. Moore "The Minister and the People of God," Quarterly Review 3 (1983): 33-49.

${ }^{3}$ See Congar, pp. 14-15; Paul Gordon Johnson, Buried Alive (Richmond: John Knox Press, 1968), p. 14 .

${ }^{4}$ Congar, pp. 12-13. 
monopoly of the Roman see."l But there were lay renewal movements again and again. As mentioned above, the Protestant Reformation rediscovered the priesthood of all believers.

But even in Luther's time, the principle was not carried out in practice. For the safty of order and the proclamation of the word it was necessary that some be appointed to the "office" of minister . . .2

Calvin exalted the authority of the minister and neglected the importance of the laity. Nevertheless, the Reformation influenced the development of democracy. 3 There may even be connections between the new emphasis on the laity and the development of human rights. 4

Today because of the increasing secularization, which has diminished the public influence of the clergy, and because of results of modern biblical scholarship, the importance of the laity is stressed again. 5 The

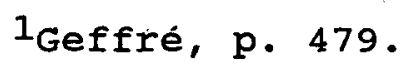

2Alden Drew Kelley, The People of God: A study in the Doctrine of the Laity (Greenwich, Connecticut: Seabury Press, 1962), p. 70 .

${ }^{3}$ Elton Trueblood, Your other Vocation (New York: Harper \& Brothers, 1952), p. 32 .

${ }^{4}$ see La Laicité, published by Université d'AixMarseille, Centre De Sciences Politiques de l'Institut d'Études Jurisdiques de Nice (Paris: Presses Universitaires de France, 1960), p. 145.

${ }^{5}$. Fouseca, "Secularization and Evangelization," in Evangelization, Dialogue and Development: Selected Papers of the International Theological conference, Nagpur (India) 1971, Series: Documenta Missionalia--5, ed. Mariasusai Dhavamony (Rome: Universita Gregoriana 
church is now regarded "as God's people rather than as an hierarchical institution."l Even in Catholic theology there was a movement from the understanding of the laity as the bridge between church and world to the view that the laity is the church. The future church has even been described as a declericalized church.

The clergy/laity distinction has set up many false problems for the Church, and will go on doing so as long as it is retained, since it represents a principle alien to the nature of the church as a society. Talk of a "distinctively clerical" or a "distinctively lay" point of view is nonsense. The lay person does not belong to the Church, nor does he have a role in the Church. Rather, through baptism he is church, and in union with christ, his mission is the mission of the church herself... The baptized, therefore, is not only a man of the church at the heart of the world, but also a man of the world at the heart of the Church. 2

In general there is growing awareness that "the laity are not the helpers of the clergy so that the clergy can do their job, but the clergy are helpers of the whole people of God so that the laity can be the Church." 3 No ordained one is placed in a special order of

Editrice), p. 357, calls for an updating of the relationships between the laity and the hierarchy.

${ }^{1}$ Lambeth Essays on Ministry, published by the Archbishop of Canterbury (London: S. P. C. K., 1969), pp. 3-4.

2 Leonard Doohan, "Contemporary Theologies of the Laity: An Overview since Vatican II," Communio: International Catholic Review 7 (1980):237, 241-242. That, however, does not mean that the catholic church is willing to renounce its hierarchy. See congar, pp. 143-145.

\footnotetext{
${ }^{3}$ Lambeth Essays on Ministry, p. 14 .
} 
priests above his brethren. "The church is now ready for, and its God-given mission now demands, the complete abandonment of the clergy-laity distinction."1

In this study, however, the terms laity and clergy are used according to the common understanding: laymen are non-ordained church members. Clergymen are professional and ordained church members, that is pastors or evangelists who are employed by an ecclesiastical institution. Both groups belong together and form the one priesthood and the one church.

\section{The unchurched}

The unchurched person is defined as one who does not belong to a church and who has not attended a church for at least six months apart from special occasions like weddings, funerals, or special holidays. That does not necessarily mean that unchurched people are not religious people. They may believe in God, but have drawn back from the institutional church. 2 unchurched are also those who are indifferent to religion, as well as those who are

1 Moore, pp. 42-43. See R. C. Johnson, ed., The Church and Its Changing Ministry (Philadelphia: Office of the General Assembly - The United Presbyterian Church in the United States of America, 1961), p. 29; Marney, p. 14 .

${ }^{2}$ Winfield Arn, ed., The Pastor's Church Growth Handbook, 2 vols. (Pasadena: Church Growth Press, 1982), 2:129 and passim, has a survey made by G. Gallup which reveals interesting data on the unchurched in the United States of America. However, this cannot be applied to the situation in Europe and in West Germany. 
atheists. In Europe the unchurched people are the vast majority of the population. Only a rather insignificant percentage of the population constitutes the people who attend church regularly. Although the Seventh-day Adventist Church must proclaim the everlasting gospel to each person--including the people that attend their churches regularly, the challenge, at least in Europe, is for this church to reach the vast majority of unchurched. These also have needs. They suffer from marriage conflicts, illness, loss, bereavement, change, and death. Thus, when the church tries to reach them, they too are somewhat receptive.

In dealing with the unchurched, a major characteristic with which one is confronted is "the secular mind-set." William G. Johnsson defines this secular mind-set as follows:

1. Indifference to religion. Attitudes range from ignorance of religion to outright antagonism and embrace all religions and christianity in particular. The secular man or woman has come to disregard all forms of organized religious faith or worship. The secularist feels that he has outgrown religion; he may regard himself as post-Christian.

2. Confidence in the achievements of science and technology . . .

3. Self-sufficiency. The secularist does not necessarily deny the existence of God--he simply does not feel the need of Him. He thinks he can get along quite well without Him--if He does exist. Indeed, he looks more to human abilities and resources as all-sufficient to meet human needs than answers from any other source. . .

- . Many people who still believe in God and even go to church are practical secularists. In the 
final analysis they rely on human solutions rather than on God.1

There is a variety of secular people. L. L. Bock and H. M. Rasi list: (1) The religious dropout, (2) the relativist, (3) the materialist, (4) the pragmatist, (5) the indifferent, (6) the humanist, and (7) the atheist. 2 The secular mind is interested in functional and pragmatic thinking. "The goal is not necessarily truthfulness, but usefulness." 3 A secular world no longer thinks in an ontological way. It is liberated from the supernatural things.4 It is a "technopolis

$1_{\text {William G. Johnsson, "The Challenge of Secular }}$ Thought," in Meeting the Secular Mind: Some Adventist Perspectives, selected working papers of the committee on Secularism of the General conference of Seventh-day Adventists 1981-1985, ed. Humberto M. Rasi and Fritz Guy (Berrien Springs: Andrews University Press, 1985), pp. 16-17. See Harvey Cox, stadt ohne Gott, 5 th ed. (Stuttgart: Kreuz-Verlag, 1969), pp. 11-13, 95. See also Langdon Gilkey, Society and the Sacred: Toward a Theology of Culture in Decline (New York: Crossroad Publishing Company, 1981), pp. 17, 92-93, 101-102.

${ }^{2}$ Lowell L. Bock and Humberto M.Rasi, "Report and Recommendations to the General Conference Committee," in Meeting the secular Mind: Some Adventist Perspectives, pp. 184-185. Mark A. Finley, "Target and Tactics," in Meeting the secular Mind: Some Adventist Perspectives, pp.101-102, distinguishes four basic types of secularists: (1) the secular materialist, (2) the secular religious dropout, (3) the secular hard hat, and (4) the secular philosopher.

${ }^{3}$ Robert M. Zamora, "The Gospel of the Abundant Life," in Meeting the Secular Mind: Some Adventist Perspectives, p. 128. See Gottfried Oosterwal, "The Process of secularization," in Meeting the secular Mind: Some Adventist Perspectives, p. 50, and Cox, p. 73 .

${ }^{4}$ see H. Cox, p. 78 
characterized by anonymity, mobility, pragmatism, and profanity," according to Harvey Cox.1 It has four basic traits: contingency, autonomy, temporality, and relativity.2 This secular mind-set pervades the entire society, even the whole world. It may come in somewhat different shapes, but it is a philosophical system which intrudes in the churches, too. Its values and practices are success-orientation, self-preoccupation, passivespectator attitude, elitism, competition, striving for affluence, ethnocentrism, and the end justifying the means. 3

Coming back to the difference between the United States and Europe and comparing both regarding the phenomenon of the secular mind-set, or "secularization," one discerns a significant difference:

For example: in a large number of countries in Europe, secularization expresses itself to a large extent in a sharply reduced church attendance and membership, a decline of religious institutions, and even an anti-organized-religion (antichurch) attitude. In Northern and Western Europe, barely 10 percent of the population has any meaningful relationship with the church. This contrasts sharply with the situation in the United states, where about 40 percent of the population attends church more or less regularly, where religious institutions do persist, and where a number of churches even show an increase in membership. 4

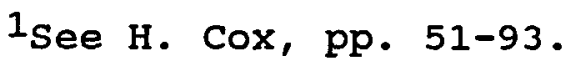

${ }^{2}$ See Oosterwal, pp. 53-54.

${ }^{3}$ See Bock and Rasi, p. 186.

4 oosterwal, p. 43 . 
However, "in Europe, secularization has taken on one form. It is mainly external . - In the United states. on the other hand, the process of secularization expresses itself in other forms. There it is mostly internal."l so, the church faces a challenge in both areas.

Now secularization is an ambivalent phenomenon. On the negative side it hinders the influence of religion and Christianity and undermines faith in God. Secularized people are then only concerned with the here and now. on the positive side, secularization liberates men from human traditions, from the power of state churches, and from superstition. It also creates some conditions favorable to the proclamation of the gospel in the entire world.2 That means the church has to stay away from the negative aspects--like the philosophies of autonomy, relativity, and meaningless of life--and has to use the positive aspects. The church must learn to understand secular man and to communicate with him on his level. It

\section{${ }^{1}$ Ibid. See also Engel, p. 18.}

${ }^{2}$ See Bock and Rasi, p. 181; Oosterwal, p. 47-49; and cox, pp. 11, 27. Cox makes a distinction between secularization and secularism (pp. 28-31). In his opinion a Christian should not be opposed to secularization, but should support and foster it, since secularization is a process of liberation (pp. 28, 31, 48). Pragmatism, profanity, anonymity, and mobility are not hindrances but access roads to reach modern man (p. 75). On the other hand, secularism is an ideology which forms a new religion and hinders openness and freedom. It needs to be resisted ( $\mathrm{pp} .31,48,83$ ). 
must get to know his needs and longings and must offer him some help. Then it will also be able--probably only after some time has passed--to communicate the gospel.

summing up the definitions for this study very briefly we can say:

1. Laymen are non-ordained church members.

2. Clergymen (ministers) are ordained church members.

3. Unchurched are secular people concerned mainly or only with the here and now. Usually they are selfsufficient and indifferent to religion.

The Clergyman--His Problems and opportunities

The clergyman has problems and opportunities in connection with reaching the unchurched. He has advantages and disadvantages as compared with the work of the layman. In any case, he is called by God to perform a special ministry and to work in his way on the fulfillment of the Great Commission. His sensitivity to needs, his willingness to mingle with men, and his openness to different classes of society are his gifts to reach that goal.

\section{Clergyman's problems}

Problems in regard

to himself

The problems the minister has with himself do not only influence his outreach but also the 
evangelistic outreach of the church. These problems may include:

1. Crisis of identity. Many pastors today suffer from a crisis of identity. Often they are separated from their colleagues. They have to play different roles that require a tremendous number of skills. They must be counselors, preachers, social reformers, educators, financiers, and sometimes even psychologists and psychiatrists. This extremely wide range of activities causes conflict. ${ }^{1}$ Furthermore, the pastor has to perform many of his roles in public. His work is done in a position of high visibility which often leads to an almost complete blurring between the pastor's self-image and the roles he plays. If he fails in one area, his self-image suffers, also. Emotional and psychological consequences for the pastor are tension, anxiety, neurotic anxiety, emotional turmoil, psychosomatic diseases, learned helplessness, depression, alienation from interpersonal relations and withdrawal from communication, inappropriate sexual attraction and involvement, and an integrity dilemma. There is externally structured

${ }^{1}$ See Jeffrey $\mathrm{K}$. Hadden, The Gathering Storm in the Churches (New York: Doubleday \& Company, 1969), p. 218; and Michael G. McBride, "Role Conflict and Role Ambiguity Applicable to the Local Pastor in the North Pacific Conference of Seventh-day Adventists" (D.Min. project, Andrews University, 1984), pp. 17 and passim. 
role conflict, conflict between internal and external norms, and conflict between internal norms. 1

2. Crisis of belief. Pastors often suffer from a crisis of belief, also. They have theological questions and problems.

Doubt has served to shift the clergyman's emphasis away from the next world to a deeper concern about the meaning and implication of the christian faith for this world . . . Laity have stronger beliefs about God than do clergy.2

Problems in regard

to the unchurched

1. Separation from the common life. The minister is usually separated from the common life. Often he has no direct influence on the community, so there is little or no contact with the real world of the people. He lives in his own world. This makes it difficult to understand people and to minister to them effectively. 3

2. The danger of a manipulative attitude. Because of the desire to be successful and because of the pressure coming from the local church and the administration, professional evangelists and pastors tend to

1McBride, pp. 22-49, 58-59.

${ }^{2}$ Hadden, pp. $221,201$.

${ }^{3}$ See Robinson, p. 65. In his opinion Christianity today is irrelevant to current problems, and a minister can hardly come in contact with them. He is separated from modern life. His world is met with suspicion. Because he gets paid for proclaiming the gospel, many think it to be a part of his propaganda. See also Marney, p. 14 . 
manipulate people to win them for christ. In this case they do not deal with them as partners or equals. A meaningful dialogue becomes almost impossible. High pressure may be used. 1

3. Stress on denominational differences. Usually pastors lay stress on denominational differences more than lay people do. ${ }^{2}$ It is not at all bad to discern clearly the identity of one's church, but stressing the differences may be overdone and it may come too early, namely, when an unchurched person has not yet made a clear-cut decision for Jesus Christ as his personal Savior and Lord.

4. Difficulties with the follow-up. When seminars and campaigns conducted by clergy are over, the minister really has problems if he is left alone to minister to the great number of interests. Moreover, if the audience had focused on the professional evangelist or pastor and built some kind of relationship with him,

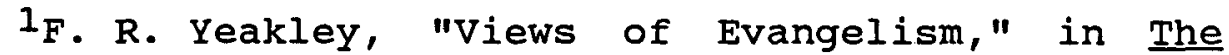
Pastor's Church Growth Handbook, 2 vols., ed. Winfield Arn (Pasadena: Church Growth Press, 1982), 2:140 and passim, detected three different models of evangelism: (1) the information transmission model, (2) the manipulative dialogue model, (3) the non-manipulative dialogue model. Research has shown that the last one is the most effective one. There are only a few drop-outs as compared with the manipulative model. The importance of genuine dialogue is also stressed by Jon Paulien, "The Gospel in the secular World," in Meeting the secular Mind: Some Adventist Perspectives, p. 36.

2 See Henry Clifton Brown, Messages for Men (Grand Rapids: Zondervan Publishing House, 1960), p. 63. 
interested persons may not be content to have Bible studies "only" with a layman. They want to talk to the "expert."

Problems in regard to the laymen

1. Gulf between minister and layman. Although contemporary theology stresses the priesthood of all believers and the importance of laymen, nevertheless many pastors and evangelists still live on a pedestal. When this is the case, they are often left alone and have no support from the laymen. There are tensions. Laymen are no longer content to be mere servants of the "experts." Instead of training the laymen, the minister may too often perform the work of the laymen. 1

2. Misunderstandings. Often pastors are interested in social action. The church does not understand this interest and involvement, because it is not involved itself. This creates additional tension. 2

${ }^{1}$ See Eph 4:11-12; Douglas Pursey Blatherwick, $\underline{A}$ Layman Speaks (London: The Epworth Press, 1982), pp. 88-89; Hadden, p. 219; Barbara Brown Zikmund, "Christian Vocation - in Context," Theology Today 36 (1979):329, 336; Walter A. Henrichsen and William N. Garrison, Layman, Look Up! God Has a Place for You (Grand Rapids: Zondervan Publishing House, 1983), pp. 81, 97. William E. Diehl, Thank God, It's Monday! (Philadelphia: Fortress Press, 1982), p. 185; Keeley, p. 78 .

2 see Richard J. Mouw, Called to Holy Worldliness (Philadelphia: Fortress Press, 1980), p. 72 ; Hadden, p. 230 . 
Problems in regard to denominational structure

High expectations. The pastor has a unique office in the organization of a denomination. Therefore he has to suffer from high expectations and pressures on the side of the administration and on the side of the local church. This may hinder his effectiveness. 1

\section{Clergyman's opportunities}

Opportunities in regard to the unchurched

1. Openness and sensitivity. The minister is usually more sensitive to the needs of the people than laymen are. He is also more willing to mingle with the unchurched. He feels comfortable in their presence. He is also more responsive to the problems of the outcast because he is not confined to the middle class or to his race: he often has an open attitude. ${ }^{2}$ This helps him to reach these people.

2. Experience in conducting public meetings. since the professional evangelist and the pastor have more experience in conducting public meetings than the layman, they usually are more successful and get more decisions. The meetings may well be held in a more professional manner and draw a larger crowd.

\footnotetext{
$1_{\text {McBride, pp. 19-21. }}$.

${ }^{2}$ see Hadden, pp. 99, 109, 159.
} 
opportunities in regard

to the laymen

1. Better education in evangelism. The minister has the advantage--besides his experience--to have a better theoretical and practical training in evangelism than the layman has.

2. Example for lay evangelists. The minister also is able to set an example for laymen as to how to conduct public meetings. He can function as trainer.

opportunities in regard to

denominational structure

oftentimes the pastor or evangelist gets more support from the denominational administration, as well as from the local church, than the layman gets. This support may consist of finances, staff personnel, and help with the advertising.

The Layman--His Problems and opportunities

Not only does the clergyman have problems and opportunities related to evangelism. Doubtless, if world evangelism is ever to succeed, the laity's problems and opportunities of the laity are crucial.

\section{Layman's Problems}

Problems in regard

to himself

As does the minister, so also does the layman have problems with identity. Those problems also affect 
his outreach to the unchurched. The layman is said to suffer from a threefold crisis: ${ }^{1}$ (1) A crisis of meaning and purpose, (2) a crisis of authority, and (3) a crisis of belief. 2 For example, research on 8,000 laymen of the United Church of Christ denomination ${ }^{3}$ shows that 61 percent have low or moderately low involvement in the life of the church; 47 percent have low and moderately low religious knowledge; and 78 percent have low and moderately low devotional life. The index of belief orientation shows that 43 percent have low and moderately low belief orientation. The statistics on educational achievement show that persons with a good education are more involved in the church life than the others, and their religious knowledge is the highest. On the other hand, they are at the end of the scale in their devotional life and their belief orientation. The same is true for persons in a high socio-economic class. Because of their low devotional and belief orientation, one wonders how effective they are in witnessing. In addition, the index of the individual conscience of 31

${ }^{1}$ see Hadden, pp. $6,15,26$.

${ }^{2}$ see C. W. Brister, people who Care (Nashville: Broadman Press, 1967); pp. 34-35. He says that the layman not only is uncertain how he should think about God, but that he also feels inadequate against rivals of the christian faith, against the varieties of unbelief.

${ }^{3}$ Thomas Charles Campbell and Yoshia Fukuyama, The Fragmented Laymen (Philadelphia: Pilgrim Press, 1970), pp. 59 and passim. 
percent shows moderately high and high responses. Moderately high and high collective social responsibility prevails in 29 percent of those studied. 1

Problems in regard to the unchurched

1. Less sensitivity to needs. Generally, laymen tend to be less sensitive to the needs of people. They tend to have more prejudices than the clergy ${ }^{2}$ and are not open to certain classes, reaching only their own group. According to Brown, they tend to have a blind spot in regard to social, political, and race issues. ${ }^{3}$ If, however, the sensitivity. in laymen increases, then a greater impact on society becomes possible, because they may be closer to the common life than the clergy are.

2. Separation from society. Although the layman lives and works among the unchurched, his life oftentimes is restricted to his family and home and to the church. He may live in a "pious ghetto" 4 and be afraid of getting

IIbid, p. 224, they state that the devotional orientation is important "as one means by which the church begins to more adequately fulfill its function."

2 see Georgia Elma Harkness, The church and Its Laity (New York: Abingdon Press, 1962), p. 129; Listening to Lay People, published by the National Council of the Churches of Christ in the United States of America (New York: Council Press, 1971), p. 21.

${ }^{3}$ see Brown, p. 63 .

${ }^{4}$ Frederik K. Wentz, The Layman's Role Today (New York: Doubleday \& Company, 1963), pp. 13 and passim, compares the parish ghetto with a train passing by. You 
infected by the culture. He may no longer have any non-Christian friends. 1

3. Gulf between the sacred and the secular. Sometimes the layman lives a double life. One day per week he is pious and behaves like a Christian, while six days a week he tends to act according to secular principles. 2

There is a sharp split between his church experience and the rest of his life . . . Recently some Americans who claimed they considered religion something "very important" were asked "Would you say your religious beliefs have any effect on your ideas of politics and business?" $54 \%$ answered "no". 3

Jacques Ellul has expressed the dilemma rather sharply:

- . on the one hand, there is a minister who does not know the situation of the world, and on the other hand there are "laymen" who are very careful to keep their faith and their life in different compartments - . Theological truth has no point of contact with the world. 4

can see the people inside eating, talking, laughing. But they are entirely sealed off. He calls this "churchnarcissism", "self-admiration", "edifice complex". See also Hadden, p. 207 ; Brown, p. 64.

${ }^{1}$ See Joseph C. Aldrich, "Lifestyle Evangelism-Winning through Winsomeness," Christianity Today 27 $(1983): 13$.

2 see Diehl, pp. 171, 187; Brister, p. 33; R. C. Johnson, p. 9. According to Henrichsen and Garrison, p. 35, this compartmentalizing is also seen in the fact that laymen reach out to the unchurched in the evening, but not in the factory during work time. See also Wentz, The Layman's Role Today, p.17.

${ }^{3}$ Ibid. , pp. 6-7 .

${ }^{4}$ Quoted in Kelley, pp. 40-41. 
This split sometimes leads to flagrant Christian misconduct, indolence, moral laxness, and superficiality which reflects spiritual immaturity. 1 on the other hand it requires a crippling compromise. ${ }^{2}$

4. Lower motivation. Laymen often have a lower motivation than ministers. After a negative experience in their witnessing, they tend to draw back. Some also feel that their prestige is lowered when they confess their faith publicly. ${ }^{3}$ Many are also discontent with their jobs, 4 and this inhibits motivation to witness by life and word at one's working place.

5. Wrong approach. Laymen often talk instead of listen. They prefer the monologue instead of using the dialogue.

6. Tendency not to lead to decisions. Usually lay evangelists in West Germany are great in giving sermons and lectures, but they are weak in getting people to make decisions. So, they need training in this area. 5

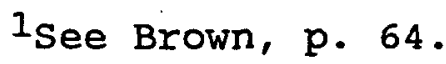

${ }^{2}$ See Wentz, The Layman's Role Today, pp. 6-7.

${ }^{3}$ Carl Gerhard Kromminga, The communication of the Gospel through Neighboring: A study of the Basis and Practice of Lay Witnessing through Neighborly Relationships (Franeker: T. Wever, 1964), p. 227.

${ }^{4}$ see zikmund, p. 331.

${ }^{5}$ Besides training sessions with role play and besides personal visitation along with an experienced worker, lay evangelists might read Mark Finley, 
Problems in regard

to the minister

1. No training in evangelism. Compared with the professional evangelist and the pastor, the layman has almost no training in evangelism. Usually he does not get it from either his pastor or an evangelist. 1 If he really gets some training, it is normally only a theoretical one. Laymen need on-the-job training and they often would like to have some. ${ }^{2}$

2. Active pastor-passive sheep mentality.

Most local congregations have developed an "active pastor-passive sheep" structure that complicates the whole work of evangelism. Converts believe they are saved to be served rather than to become servants of the Lord. 3

Entscheidungen - Menschen für Christus gewinnen (Hamburg: Advent-Verlag, 1986).

${ }^{1}$ see Diehl, p. 188 .

${ }^{2}$ Edwin Carl Linberg, "An Examination of the Role of the clergy as an Enabler of the Development and Growth of the Ministry of the Laity" (D.Min. project, School of Theology at claremont, 1975), p. 267, states: ". . I'm convinced laity have both interest in training and a willingness to be trained so they may be better equipped for ministry."

${ }^{3}$ Hollis L. Green, Why Churches Die: A Guide to Basic Evangelism and Church Growth (Minneapolis: Bethany Feelowship, 1972), p. 186. See also Dr. Knorr, "Der Dienst des Laien in der Gemeinde," in Laien an die Front! Zeugnisse für den Laiendienst in der Gemeinde, ed. Oskar Hammelsbeck and Walter Müksch (Wuppertal-Barmen: Verlag "Der Rufer", Hermann Werner, 1938), pp. 15-21. Stephen L. Sterner, "What Laity Expect of Clergy: A Case study" (D.Min. project, Lancaster Theological Seminary, 1980), p. 59, says that evangelism is one of the areas where laity expects the pastor to be in charge. 
Problems in regard

to the church

1. Misunderstanding of role. In many churches the laymen are still regarded merely as servants of the minister. They are the "unemployed of the church."l This misconception tends to promote inactivity. ${ }^{2}$

2. Less recognition and support. "The prophet has no honor in his own country." This is often true for the layman, also. He may feel abandoned by his church, without sufficient support for his work. 3

\section{Layman's opportunities}

Opportunities in regard to the unchurched

1. Recognition as expert. If the layman is a professional, an expert in a certain area; if he holds, for example, a professional or academic degree in psychology, medicine, or geology, he may actually get more recognition by the audience and have more success in drawing people than the clergyman.

2. No stigma of being a clergyman. When a layman bears witness to his Lord, his testimony may be more easily accepted than that of the minister. The layman is not an official and he is not paid for the proclamation

${ }^{1}$ see Kelley, p. 47 .

$2^{2}$ see Brown, p. 146 .

${ }^{3}$ See Listening to Lay People, p. 11; Kelley, p. 47 . 
of the gospel. He belongs to the same group of persons that he addresses, and he lives on their level. His words often have a certain freshness and come as a surprise to the unchurched, even if his words are identical with the minister's. 1

In general it is always better to have a sermon given by the layman than by a pastor, providing the lay person can give it equally well, and it is better to have a call made by a layman, providing similar conditions are met. 2

3. Closer to the common life. The layman lives among men. He is not an outsider. He has daily contacts with the unchurched and can reach far more than the minister ever can. If he is sensitive, he understands the masses and their problems, needs, and desires much better than the clergyman does. The layman "can be in the world in a manner which is impossible even for the most 'wordly' clergy."3 If he lives as an example in the every-day life, his proclamation of the gospel will have a powerful influence. 4 There are so many avenues of

${ }^{1}$ see Blatherwick, p. 41; Robinson, p. 24 .

2 Trueblood, p. 41 .

${ }^{3}$ Lambeth Essays on Ministry, p. 7; see Marney, p. 14. Christa Grengel and Dietrich Mendt, eds., Der Laie in Gemeinde und Kirche - Materialien der Bundessynode vom 13. bis 17. Mai 1977 in Görlitz (Berlin: Evangelische Verlagsanstalt, 1979), pp. 218-219.

p. 132 .

${ }^{4}$ see Robinson, p. 68; Brown, pp. 146, 63; Mouw, 
service open to him that allow him to reach the unchurched. 1

Opportunities in regard

to the pastor

1. Endowed with the gift of evangelism. The gift of evangelism is not reserved to the professional evangelist. "Peter Wagner's research leads him to the conclusion that, with some variation, perhaps $10 \%$ of a church's members have the gift of evangelism." 2 "Therefore effective evangelism depends on identifying, recognizing, and using these gifts." 3 when we leave public evangelism to professional evangelists only, we are not using God's gifts correctly. On the other hand, the local pastor may not have been given this gift. Laymen with the gift of evangelism, therefore, have tremendous responsibilities and opportunities for service.

2. Identification with own efforts. When laymen are working with their own programs, they identify with

${ }^{1}$ see Paulien, p.33; Oosterwal, p. 51; Bock and Rasi, p. 190.

${ }^{2}$ George G. Hunter, "Equipping Church Laity for Evangelistic Ministry," in A Celebration of Ministry: Essays in Honor of Frank Bateman Stanger, ed. Kenneth Cain Kinghorn (Wilmore: Francis Asbury Publishing Company, 1982), p. 104 .

${ }^{3} \mathrm{H}$. A. Snyder, "An Evangelistic Lifestyle for the Congregation," in Missions, Evangelism, and Church Growth, ed. C. Norman Kraus (Scottdale: Herald Press, 1980), p. 98 . 
them much more than with the programs of someone else, because they themselves have set the goals and have developed these programs; they tend to work harder.

Sociological studies in organizational development have discovered that any group of workers who feel they are being used to achieve goals that belong only to the leadership will resist the goals and consciously or unconsciously sabotage their achievement. 1

3. A larger number of campaigns. Since there are many church members with the gift of evangelism-and at least some of them can and will use this gift for public proclamation of the gospel--many more campaigns can be held. There also tends to be continuity in the campaign and its follow-up.

The Unchurched--Reaching Them for Christ

If the mission of the church to reach the unchurched is to be successful, (1) the enormous task lying ahead must be recognized, (2) the necessity of the active involvement of each layman in this endeavor must be acknowledged, and (3) the gap between clergy and laity must be cured. clergy and laity belong together and need

1J. W. Fowler, "Helping People Work Togehter," Ministry, October 1985, p. 5; see Kenneth O. Cox, "Evangelistic Problems and Suggestions," in Meeting the Secular Mind: Some Adventist Perspectives, ed. Humberto M. Rasi and Fritz Guy (Berrien Springs: Andrews University Press, 1985), p. 83. 
each other.1 The "indispensability of the laity" has to be admitted, for their "involvement . . in active ministry is a matter of life and death." 2

To reach the unchurched one has to: (1) Prepare oneself, (2) prepare the church for outreach, and (3) look for avenues to reach them.

1. Preparing oneself--whether layman or minister--for outreach. The evangelist should have:

a. A clear understanding of himself, of God, of the Christian faith, of the church, of the world, and the society. This is essential. 3 b. A clear vision of his mission. 4

${ }^{1}$ See Kelley, pp. 40, 82; Brown, p. 147; Diehl, p. 181; Lambeth Essays on Ministry, p. 6; Harkness, pp. 145, 156; Listening to Lay People, pp. 13-14.

${ }^{2}$ S. J. Emmanuel, "Some Mission Priorities That Determine and Demand New Lay Ministers," Zeitschrift für Missionswissenschaft und Religionswissenschaft 61 (1977): 256-270.

${ }^{3}$ See Mouw, p. 131. He also talks about openness for self-examination. The clear understanding just mentioned must not be a theoretical one. It also includes daily prayer and perhaps a periodical retreat; daily study of the scriptures and other books; fellowship in church worship and in small groups that study, pray, and share: that means living in a rhythm of withdrawing from the world once a week and penetrating it once more; faithful service, identification with the suffering ones, global consciousness; and stewardship in drastic disciplining of time, energy, and money and in resisting competition and a lean life-style. Frederik K. Wentz, Getting into the Act (Nashville: Abingdon, 1978), pp. 108 and passim; Wentz, The Laymen's Role Today, pp. 33, 216.

$$
{ }^{4} \text { see Arn, p. } 146 .
$$


c. A willingness to be educated and trained in this area. 1

2. Preparation of the Church for outreach.

a. In preparation of the church, the tensions between clergy and laity must be reduced and must be replaced by a high commitment to shared ministry and to a collegial and participative leadership style. ${ }^{2}$

b. Leadership is still needed. Stressing the role and the importance of the laity does not downgrade their brethren, the leaders of the church, who have to act as trainers, facilitators, and equippers.

c. The entire church has to be motivated. New members need at once to be sent into some "work of ministry." On this motivation the pastor has to work constantly. Motivators include:

\section{${ }^{1}$ See Brown, p. 65 .}

${ }^{2}$ See D. P. Smith, "Shared Ministry," Theology Today 36 (1979):344-345, Hollis Allen Miller, "Developing a Ministry of Evangelism among the Laity in a Southern Iutheran Church: Its Implications for Parish Renewal" (D.Min. project, Drew University, 1984), p. 63, Engel, p. 92 ; C. Peter Wagner, Your Church Can Grow: Seven Vital Signs of a Healthy Church (Ventura: Regal Books, 1984), pp. 77 and passim, 168; Kennedy, pp. 13, 15, 17. 
achievement, recognition, a challenging work, responsibility, and personal growth. ${ }^{1}$

d. The church also needs a vision, a dream, a goal for its mission. But this goal must be its own goal. When the goal is really owned by a church, something happens. "People are motivated by their own goals."2

e. Diversity in gifts and therefore also diversity in methods to reach the unchurched has to be acknowledged. This diversity is not opposed to unity. ${ }^{3}$ The church is one body with different functions. To reduce it to one single kind of ministry harms the organism.

3. Searching for avenues to meet the unchurched. a. In order to meet the unchurched, laity and clergy have to know the felt needs of their target group and have to respond to these needs. 4 Maslow's hierarchy of needs points to basic needs almost everyone has: physiological needs, safety,

${ }^{1}$ See Arn, p. 148. De-motivators include: lack of administration, poor supervision, poor inter-personal relationships, lack of status and security. It is important to keep motivating by recognizing efforts and results, by being committed to people's ability to do it, and by avoiding comparing people with people.

${ }^{2}$ Ibid., p. 146.

${ }^{3}$ See Margaret Kane, Theology in an Industrial Society (London: SCM Press, 1975), p. 114 .

${ }^{4}$ See Kromminga, p.233; H. Cox, pp.148, 177. 
belongingness and love, esteem, and self-actualization. 1 Needs of secular people often include: community, structure, meaning, harmony with nature, 2 a positive outlook into the future, ${ }^{3}$ health, 4 readjustment to change, 5 etc. 6

${ }^{1}$ see Engel, pp.112-114.

${ }^{2}$ See Paulien, pp. 30-39. Gilkey, pp. 17, 24, 92-93, 95, 101-102, describes the secular man's belief in science, technology, industrialism, and progress. He is left, however, without a framework to find answers to the questions about the meaning of life, about good and evil, etc. A change in thought and feelings with regard to the confidence in science and technology in the last decades has caused anxiety in modern man. See H. Cox, pp. 81-82, 86, 93 concerning the question about meaning in life. Alvin Toffler, Der Zukunftsschock (Berlin: C. A. Koch's Verlag Nachf., 1970), pp. 289, 295, 297-306, 312 , 328-330, says that one needs clear-cut values and priorities, the ability to screen stimuli, and zones of stability (cf. the Sabbath) to be not overcome by the future shock. He also stresses the importance of small groups and face-to-face counseling, which should be performed by laymen (p. 306). A home-sickness for the future may also help to deal with the future shock (cf. biblical eschatology).

${ }^{3}$ see Howard B. Weeks, "Lengthening the cords, strengthening the stakes (Some Thoughts on an old Theme)," Meeting the Secular Mind: Some Adventist Perspectives (Berrien Springs: Andrews University Press, 1985), p. 96.

${ }^{4}$ see White, The Ministry of Healing, pp. 19, 172, 141,$144 ; \mathrm{H}$. Cox, p.153. According to polls made in 1985, the desire to be healthy takes the top priority among other wants in Germany; 23 percent of the German population voted for health as their most important desire. See "Gesundheit statt Geld," Factum, July/August 1986, p. 30.

${ }^{5}$ See Engel, pp.120-125.

${ }^{6}$ See also Administry, summer 1984 , on awareness activities, and Administry, Winter 1985, on entry events. 
b. Sometimes it is helpful to concentrate on a certain class. Because the Great Commission includes all the world, the church must also work for different classes and groups. To reach a class which is different from one's own, inculturation is necessary. 1

c. Hospitality helps to build friendships. 2

d. Neighborliness is an excellent means to get in touch with the unchurched. 3

e. Small groups usually help to develop a sense of belonging and caring and mutual support. 4 For an unchurched person, a small group can be very attractive. Groups for children such as Pathfinder clubs are important. Many parents are interested in good programs for their children.

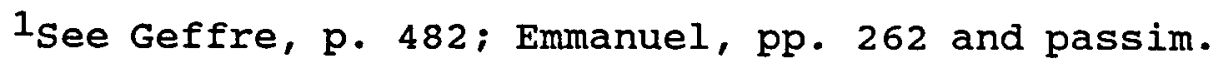

${ }^{2}$ see Aldrich, p. 15.

${ }^{3}$ See Kromminga, p. 232: "Perhaps when he (the neighbor) has an opportunity to help as well as to be helped, he will begin to be liberated from the shackles of self-concern and self-interest."

${ }^{4}$ See Smith, p. 341 ; Emmanuel, p. 259. 
f. The example of individuals and of the entire Christian community by their life-style can be a mighty witness for the unchurched. 1

g. Dialogue is important in communicating with the unchurched. 2 It shows that a person is taken seriously. There may not always be readymade answers for certain questions. That is not entirely bad: it may only stress one's openness and authenticity. The opportunity for dialogue should also be provided in evangelistic campaigns.

\section{Summary}

The ministers and the laymen of the church are in reality only one laity. Nevertheless, both groups are somewhat different from one another. They both have certain problems and difficulties in reaching the unchurched. Both groups also have unique opportunities to reach the secular society. The advantages the laity have and the advantages the clergy have to come in contact with society outside the church are complimentary. Therefore both groups have to work together very closely as partners. Society needs the ministry of the laymen who

${ }^{1}$ see Lambeth Essays on Ministry, p. 23: "The Christian church should be a demonstration in society of what society should be like."

$2^{2}$ ee Geffré, pp. 479 and passim; Kelley, p. 55. 
live among secular men and know their hopes, fears, and needs. Society also needs the ministry of the clergymen who are more aware of social issues and are more willing to abandon prejudices and to be involved in action. The number of unchurched and their openness to a change are a great challenge for the entire church.

Faith means discerning the enormous possibilities the church has in society, to come to understand the responsibility of the entire "laity" (laymen and clergymen) for the unchurched, and to leap into this ministry of reaching them for christ with "all one's heart and with all one's soul and with all one's mind."I Again, reaching men for Christ is the main reason for the existence of the church. Both laymen and clergyman must be involved in this mission which also includes public proclamation. 2 At this point, congregational evangelistic campaigns come into the picture. Lay people--and pastors too--must neither evade their responsibility to preach the gospel in various forms, nor must they be hindered to take it. They need to think about their mission, pray about it, and implement it. They need a vision that is carried out in practice.

${ }^{1}$ see Matt 22:37-39.

2 The content of the proclamation must be adapted to the fields of interest and to the needs of secular people. 


\section{Conclusions for Congregational Evangelistic Campaigns}

Results of the Previous study

Two main points have emerged from the study thus far. First of all, the gift of evangelism is not restricted to the clergy, that is, to professional evangelists. Laymen may have this gift too, and ministers should expect to find this gift in their congregation and should help the laymen to detect this gift and use it. Second, the church is dependent on the laymen in its mission. One can only hope to fulfill the Great commission with the active involvement of the laity in evangelism. The key to church growth is in the actions and attitudes of the laymen. 1

\section{Problems with the Concept of Lay Evangelism}

However, problems with the concept of lay evangelism exist within the church. Scholars say there are three types of mission: presence, proclamation, and persuasion. 2 These types are valid for each church.

${ }^{1}$ see Lyle E. Schaller, Growing Plans: Strategies to Increase Your Church's Membership (Nashville: Abingdon Press, 1984), p. 63 .

${ }^{2}$ see c. Peter Wagner, Frontiers in Mission strategy (Chicago: Moody Press, 1971), pp. 124-134; George G. Hunter, The contagious congregation: Frontiers in Evangelism and Church Growth (Nashville: Abingdon, 1979), pp. 22-25, 31, 153; see also Paul S. Rees, "I Have My Doubts," World Vision Magazine, January 1971, p. 32 . 


\section{Presence}

The simplest kind of mission is the presence of Christians in society, living their christian life as an example. They perform the first type of mission by taking their jobs and their environment seriously. They may be administrators or politicians, artists or technicians. They may work in commissions, courts, and councils, in committees, divisions, and departments, in banks, stores, universities, firms, and corporations. It is the presence of Christians in the every-day life that draws the attention of some people to Jesus Christ. 1

\section{Proclamation}

Proclamation is done by service, fellowship, and witness. 2 Here one has two aspects: the social and the evangelistic elements. 3 whereas service and fellowship deal more with the social issues, witness refers more to the dialogue about the meaning of life, God, and the hope beyond the grave.

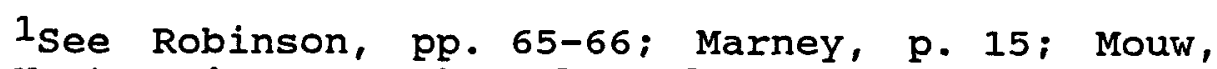
p. 133; Wentz, The Layman's Role Today, pp. 135-136.

${ }^{2}$ See $Y$. Ishida, "The Ministry of the People of God," South East Asia Journal of Theology 23 (1982):142. He suggests worshipping, witnessing, and serving. See Smith, p. 339 .

${ }^{3}$ See Mouw, p.10; Wentz, Getting into the Act, pp. 22 and passim; Harkness, pp. 143-144; Helmut Thielicke, "The Salt, Not the Honey of the World," Lead 4 (1983):119; Aldrich, p. 15. 
$\underline{\text { Persuasion }}$

Persuasion deals with the religious efforts that try to help a person come to full surrender to the Lord. Laymen or ministers wrestle in Bible studies, public evangelistic campaigns, etc., with persons who are already informed about Christ and his claims.

All three types are necessary for the mission of the church. But laymen are often content with the first aspect, namely, presence in regard to their person. And often pastors do not expect more from them or do not provide opportunities for the laity to get involved in proclamation and persuasion. If they really are involved in evangelism, it is mostly personal evangelism and not public evangelism.

In current literature one can read quite a bit about lay evangelism. Scores of books and articles have been written on this topic, but once again it is usually only personal evangelism that is referred to.1 Laymen are

1 See Abraham Philip, "Mobilization of the Laity in the Mar Thoma Church for Evangelism" (D.Miss. dissertation, Fuller Theological Seminary, 1974), p. 237 ; Hunter, pp. 100-107; S. E. Engstrom, "Evangelism and Stewardship," The Lutheran Quarterly 5 (1953):35-38; Jesse S. Reed, "Our Supreme Service," in Motivating Laymen to Witness, ed. James A. Ponder (Nashville: Broadman Press, 1974), pp. 88-93; Thomas Coates, "Some Reflections on the Mission of Christ in Asia," Currents in Theology and Mission 3 (1976):40-42; Howard E. Mumma, Take It to the People: New Ways in Soul Winning: Unconventional Evangelism (New York: World Publishing Company, 1969), pp. 90-91; Antonio Arteaga, "A study of an Evangelistic Approach for Catholics and the Nonreligious Based on E. G. White's Writings" (B.Div. thesis, Andrews 
encouraged to lead persons to Christ, to give Bible studies, to do follow-up, 1 but very seldom does one hear or read in the literature about public evangelistic campaigns conducted by laymen. Although it is stressed that there is no difference between laity and clergy, in reality, public proclamation of the gospel is still mainly reserved to the clergy. Except for a few others, 2 the Mennonites ${ }^{3}$ and the seventh-day Adventists are those

University, 1968), pp.47-48, 55; William Ward Ayer, Flame for the Altar (Grand Rapids: Zondervan Publishing House, 1952), pp. 134-137; C. John Miller, Evangelism and Your Church (Phillipsburg: Presbyterian and Reformed Publishing Company, 1980), pp. 62-69; Albert W. Beaven, "The Local Church and Evangelism," in The Message and Method of the New Evangelism--A Joint statement of the EvangeIistic Mission of the Christian Church, ed. Jesse M. Bader (New York: Round Table Press, 1937), pp. 151-157; M. E. Dodd, "The Whole Church at Work," in The Message and Method of the New Evangelism: A Joint statement of the Evangelistic Mission of the Christian Church, ed. Jesse M. Bader (New York: Round Table Press, 1937), pp. 208-209; Autrey, Basic Evangelism, pp. 58-62; G. A. Coon, Good Neighbors Evangelism: Informal Talks Volume 3 (Decatur: Mrs. G. A. Coon, Box 449, 1954).

$1_{\text {See James Kennedy, Dynamische Evangelisation }}$ (Bad Liebenzell: Verlag der Liebenzeller Mission, 1978).

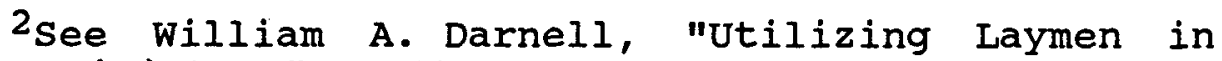
Follow-up Ministry," Southwestern Journal of Theology 17 (1975):63, who talks about lay preaching, but only in the context of evangelistic follow-up. See P. Mücksch, "Das Amt des Pfarrers und der Laienstand," in Laien an die Front! Zeugnisse für den Laiendienst in der Gemeinde, eds. Oskar Hammelsbeck and Walter Mücksch (Wuppertal-Barmen: Verlag "Der Rufer", Hermann Werner, 1938), p. 59. He does talk about lay proclamation, but in connection with the church only.

${ }^{3}$ see P. W. Wiebe "Preaching Evangelism," in Probe for an Evangelism That cares, ed. J. Fairfield (scottdale: Herald Press, 1972), pp.116-119: "We would like to see more Mennonites take up preaching as the method of 
most likely to have public campaigns recommended and conducted in some world fields by laymen. Many churches have the concept that the area of the laity is the world--laymen mingle with their colleagues and neighbors, whereas the area of the clergy is the church, and to this area belongs the public proclamation of the gospel ${ }^{1}$.

The layman proper is he who hears the Word, receives the sacraments, who is taught, shepherded, helped and governed. The layman's ministry is not in the church but in the world.2

This view often stems from a clear-cut distinction between clergy and laity. However, laymen are not restricted in their service to the world, they are also serving within the church, and pastors are not only ministering to the church, they are also reaching out to the world--and not only in public proclamation. Spiritual gifts are given to the entire church, to each

evangelism used by our Master, practiced by His disciples, and proven effective for almost 2,000 years. The results substantiate the method. There are many opportunities for evangelistic preaching today. Our congregations. The street corners and parks in our towns. The mass media. Local crusades. Business luncheons and prayer breakfasts."

${ }^{1}$ see Joseph Cardijn, Laymen into Action. (Chicago: Y. C. W., 1964), p. 118; Josef Amstutz, "Theologische Überlegungen zum Thema Mission und Laie," in Das Laienapostolat in den Missionen - Festschrift Prof. Dr. Johannes Beckmann SMP zum 60. Geburtstag dargeboten von Freunden und Schülern, ed. Johannes specker and P.Walbert Bühlmann (Schöneck-Beckenried: Administration der Neuen Zeitschrift für Missionswissenschaft, 1961), pp. 53, 60, 61.

2 John Mole, "Laymanship," Scottish Journal of Theology 14 (1961):384. 
believer, and one must not hinder the work of the Holy Spirit who endows people with gifts "as he wills." Therefore, public proclamation of the gospel is not only the task of the clergy but also a challenge for many laymen. This is seen by the Seventh-day Adventist church:

1930 Autumn Council: . . We also suggest that - . the following recommendations be adopted: - 6 6. That, in harmony with the plan laid down in the "Statement on Evangelism" to enlist the services of many of our laymen in evangelistic work, we suggest that each conference committee give earnest study to this important matter, carefully selecting laymen who give promise of success in this line of endeavor, and planning with them concerning the time, place and manners of conducting public efforts . . . 1938 Autumn Council: . . . We recommend, 1. That many more of our laymen who give evidence of ability in public evangelism be encouraged to respond to this call for self-sacrificing helpers, by conducting evangelistic efforts... 1961 Autumn Council: . . . We recommend, 1. That laymen of ability be selected by pastors in counsel with their church missionary committees and conference leaders for training and encouragement in conducting small public efforts. . . 1

\footnotetext{
Iofficial Recommendations - Department of Lay Activities, 1913-1969 (Washington D.C.: General Conference of Seventh-day Adventists, 1969), pp. 28, 32, 33. Similar recommendations were issued in other years, also. In 1976 one reads: "Realizing the importance of this form of soul winning, the General Conference Lay Activities Department has urged that new emphasis be placed on lay preaching throughout the world field." A "public lay-evangelism effort" is mentioned. Adventist Men: Lay Activities Leaflet No. 15 (Washington, D.C.: Lay Activities Department, General Conference of Seventh-day Adventists, 1976), pp. 10-11. See also the Divine Blueprint-Methods, Leadership series No. 2 (Washington, D.C.: Home Missionary Department, General Conference of Sevey Adventists, n. d.), pp. 82-83.
} 
The book wenn man dich fragt nach deinem Glauben $^{1}$ has a section in which the church member is referred to as evangelist and considers his public proclamation. ${ }^{2}$ Most important is the Lay Evangelist's Handbook, ${ }^{3}$ which notes that lay evangelism also includes public campaigns conducted by laymen. The lay evangelistic campaign is recommended for the first half of the year, whereas the pastor's evangelistic campaign may be held in the second half of the year. 4 Christian women are also encouraged to proclaim the gospel publicly. 5

The testimony of Christian laymen will often have a stronger influence for truth than the words of a preacher. 6

Summary

The problem with evangelism lies in the fact that laymen usually are not allowed or encouraged to preach

$1_{\text {The English original is Witnessing for Christ. }}$

${ }^{2}$ Wenn man dich fragt nach deinem Glauben (Hamburg: Advent-Verlag, 1986), pp. 247-253.

${ }^{3}$ Lay Evangelist's Handbook, prepared by the Lay Activities Department of the General Conference of Seventh-day Adventists (Washington, D.C.: Review and Herald Publishing Association, 1978).

${ }^{4}$ see ibid., p. 18. The laymen are encouraged: "Get started in evangelistic preaching at once. Do not wait for perfection" (p. 44).

${ }^{5}$ see ibid., p. 5: "Another secret of their success is that a number of lay women are holding public, evangelistic meetings."

$$
{ }^{6} \text { Ibid., p. } 85 \text {. }
$$


publicly or--in the case that this is recommended--that nothing happens because the recommendations are often nothing more than Iip-service. This must be changed. SDA churches in West Germany must break away from a pastorcentered approach. Laymen must get training for service, and the must get a field of ministry. Lay people can be very effective in winning persons for Christ. They need the involvement in this ministry for their own spiritual growth, and usually they like it.

\section{Suggestions for Lay Evangelism}

Taking the Bible seriously concerning laity and spiritual gifts and the priesthood of all believers, public lay-evangelistic campaigns must be advocated strongly. Pastors need to put more trust in their church members. It is not faith if the pastor believes he is the only one to proclaim the gospel effectively.

Another suggestion is that laymen work in teams in proclaiming the gospel publicly. This is what one may call congregational evangelistic campaigns.

The ideal is for groups of laymen in local churches to unite their talents in order to conduct public lay evangelistic efforts . . . Hearing the gospel of Jesus Christ presented by committed men and women of various vocational backgrounds and different ages gives unique insights into the essentials of salvation. Laymen have a common experience and an everyday language which reaches the man on the street. 1

${ }^{1}$ Ibid., p. 11 . 
Adventist Men banded together as a group-planning, working, praying--is an ideal organization to sponsor, conduct, and support a public layevangelism effort. 1

In congregational evangelistic campaigns as the term is used here, not a single person but a group of laymen proclaim the gospel in a given meeting. Another group of laymen is responsible for the next meeting within the campaign. Besides the people serving on the platform there is a staff of helpers--as is needed in every campaign. In the NT group efforts are mentioned, also: Jesus and the Twelve (Mark 6:7-12), the Seventy (Luke 10:1-12), Paul and Barnabas (Acts 14:8-18),2 Paul and other companions (Acts 15:40; 16:3-4, 11; 19:29; 20:4).3 Perhaps congregational evangelistic campaigns are a somewhat new approach for some pastors and churches-nevertheless group efforts are a very old way to proclaim the gospel.

- we need not be restricted to ways and methods which may have been fruitful in the past but may not be today. We are free, under the guidance of God - ., to seek ever new ways of fulfilling that

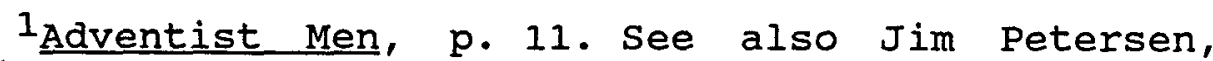
Evangelism as a Lifestyle (Colorado Springs: Navpress, 1980), p. 105: "Evangelism is also a group effort. Few of us can fulfill our part in this ministry unless we band together, and pool our resources..." Although he evidently does not talk about public campaigns, he is right in stressing the importance of team-work.

${ }^{2}$ Acts $14: 15$ and 18 explicitly state that both disciples were speaking.

3In Acts 16:13 not only Paul is talking. His companions proclaim the gospel as well. 
special obligation for evangelism that rests upon the church. 1

It is necessary today to come together as a church, to unite in considering how to win people for Christ, to make plans, and to implements them as a team. As Jesus sent out the seventy in groups of two (Luke 10:1), so SDAs in West Germany should use team efforts. Congregational evangelistic campaign are an important means to foster fellowship among church members, to get in touch with unchurched people, and to win persons for christ. The next two chapters will bring out the importance of these campaign more clearly. In any case, congregational evangelistic campaigns must be recommended strongly.

$1_{\text {Handy, p. } 93 .}$ 
A STUDY OF PREVIOUS CONGREGATIONAL EVANGELISTIC CAMPAIGNS IN WEST GERMANY

\section{Report on Previous Congregational Evangelistic Campaigns as Described in the Questionnaires and Interviews \\ Report on the First Questionnaire}

In 1986 the Seventh-day Adventist Church in West Germany had 197 pastors. These pastors received a short questionnaire with only two questions.1 The first question asked whether or not the pastor had participated in a congregational evangelistic campaign. The second question was important only in the case that the first was answered positively. It asked how many campaigns the pastor had participated in. Four possibilities were provided for the response: one campaign, two campaigns, three to five campaigns, more than six campaigns.

A total of 106 pastors returned their questionnaire, of which 78 had checked "no," they had not participated in a congregational evangelistic campaign. Thus, 38 pastors had marked "yes." Those who responded

${ }^{1}$ See Appendix 1 
positively received a second, more extensive questionnaire. Two of them that returned the second questionnaire noted that their campaigns actually were not lay efforts. That leaves only 36 "yes" responses. Since several pastors did not return the second questionnaire, one cannot be sure that all 36 "yes" responses are "yes" in reality. Nevertheless, we have to work with this figure.

Sixteen of the 36 (44.4\%) pastors that had marked "yes" had participated in one campaign; seven (19.5\%) had twice pastored a church which had conducted this kind of campaign; eight pastors $(22.2 \%)$ had participated in three to five campaigns, and five pastors (13.9\%) had been involved in more than six campaigns of this sort. Thus approximately 86 congregational evangelistic campaigns were reported by the 36 pastors. Since 93 pastors did not return the first questionnaire, the number of campaigns may be somewhat higher, but it probably would not be significantly different since persons who would mark "no" would tend not to return the questionnaire at all. Pastors who did participate in this kind of campaign would rather send back the questionnaire for it takes almost no time to check two boxes.

Report on the second Questionnaire

Twenty ministers of the 36 that got the second questionnaire returned forms. Each pastor who, had 
participated in more than one campaign got two questionnaires and was asked to report on one or two campaigns that he thought to be somewhat representative. Twenty-three questionnaires were sent back; however, two were identical, leaving twenty-two forms to consider. These represent about forty-nine campaigns. More information than asked for in the second questionnaire was provided by three pastors. 1

The second questionnaire consisted of twenty questions. They dealt with the objectives, the preparation, the implementation, and the follow-up of the campaign. 2

Analysis of the Reported Campaigns

Question 1

Five churches $(23 \%)^{3}$ had conducted this type of campaign within the previous two years. Seven churches (32\%) had done so three to five years ago. In the case of eight of the churches (36\%), the campaign was already six to ten years ago, and two pastors (9\%) marked for the campaign of their churches "more than 10 years ago". obviously, this type of evangelistic campaign has been

${ }^{1}$ For example brochures, an analysis of a congregational evangelistic campaign, and detailed information on the preparation and implementation of an outreach.

2 See Appendix 2 which includes the second letter to the pastors and the second questionnaire.

3 Percentages are given in round numbers. 
known in west Germany for several years. The majority of campaigns (55\%), however, were held during the last five-year period.

\section{Question 2}

The second question dealt with the number of meetings each campaign had. The "1-5 meetings" box was marked five times (23\%); the box "6-10 meetings" was marked fifteen times (68\%); , and "10-15 meetings" was marked twice (9\%). No one checked "more than 15 meetings." Obviously the congregational evangelistic campaign is seen as a short-term effort and usually consists of six to ten meetings. This means that this approach is not an approach to cover all the fundamental beliefs of the church. Normally it is less doctrinal than are traditional campaigns. Question $9 \mathrm{c}$ deals with this more extensively.

\section{Question 3}

When asked where the meetings were held, twenty churches (91\%) used their own church building; one a rented church building, and only one church had a public building for this type of campaign. This means that $95 \%$ of the churches decided to stay with their own meeting place. This may help the laymen who are more familiar with their own or the rented church building to be less nervous or frightened. On the other hand, a smaller crowd 
may be drawn. This effect, however, may again help the laymen who are talking publicly for the first time. They may need the support of many familiar faces and not be overwhelmed by too many guests.

\section{Question 4}

Question 4 dealt with the size of the church which had conducted a campaign. Churches with "up to 50 members" was checked three times (13\%). Churches with "up to 100 members" was checked seven times (32\%); and. churches of more than 100 up to 200 members was checked five times (23\%). Churches of "more than 200 members" was marked seven times (32\%). Although there are many small churches in West Germany, obviously a church with at least fifty or more members is more suitable to conduct this type of evangelistic effort than smaller churches. Small churches often lack the reservoir of people that is necessary to carry out this work.

\section{Question 5}

This question asked for reasons for choosing this type of campaign. Table 3 indicates the answers that were given. Of the pastors who returned questionnaires, $68 \%$ of them and their churches believe that laymen can reach the unchurched more easily than ministers can; ${ }^{1} 50 \%$ believe that the church will be revived by having a

Isee chapter 1 . 
congregational evangelistic campaign. These were the two main reasons for having such a campaign. These reasons are at the same time expectations. Question 14 and question 15 refer to these expectations and their accomplishment.

TABLE 3

REASONS FOR CHOOSING THIS TYPE OF CAMPAIGN

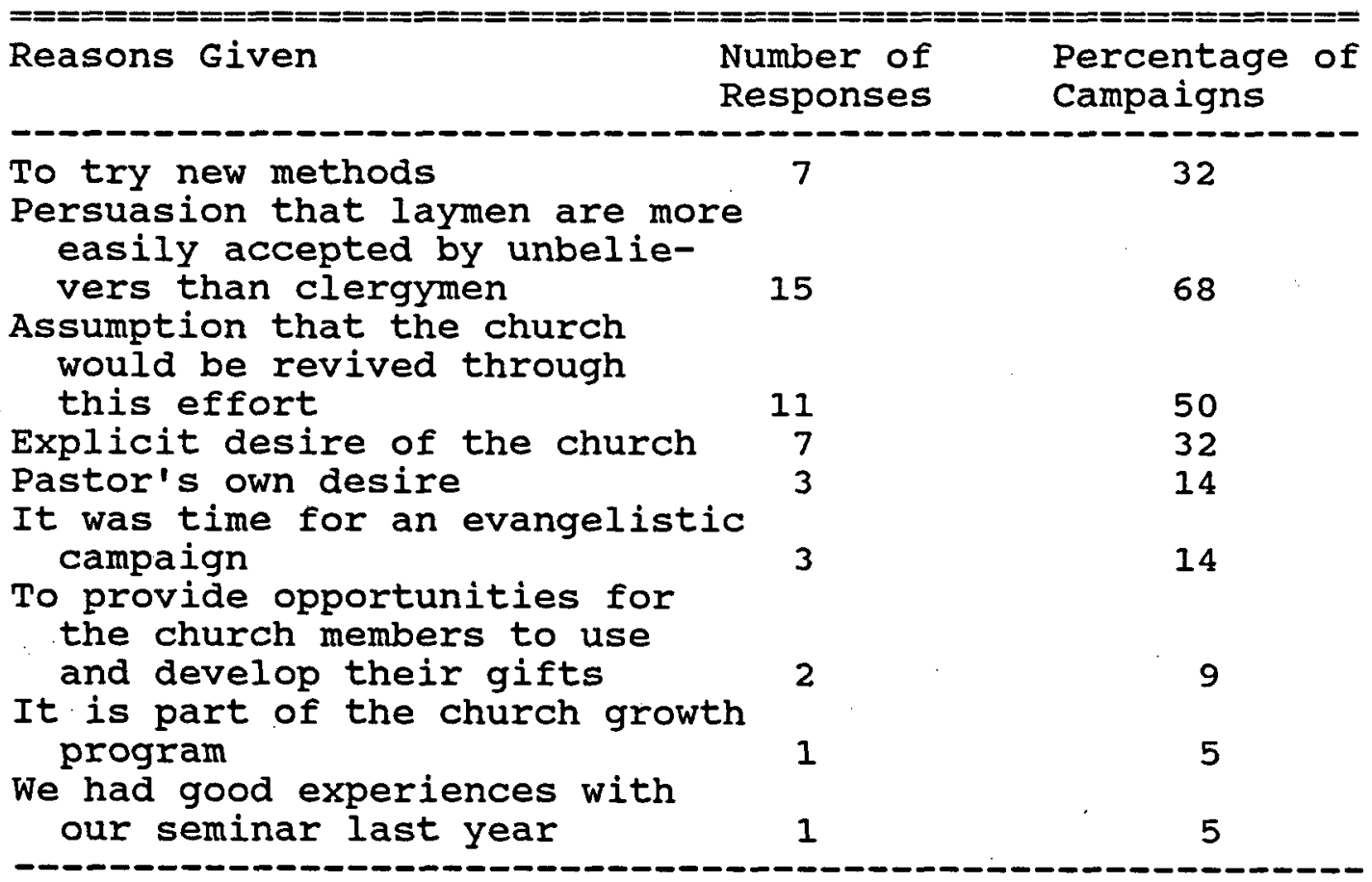

"To try new methods" is not necessarily a poor reason to conduct a campaign. Pastors and churches in West Germany suffer from a declining membership of the SDA church. It is important to use well-known methods that bring results. It is also essential to be inventive and to look for new methods to proclaim the gospel. In 
$32 \%$ of the cases, the campaign was the explicit desire of the church. Obviously these churches are mission-oriented and are willing to take the initiative to reach men for Christ. They should be encouraged to proceed on their way. Three times the pastors themselves wanted to have this type of campaign. If they use too much pressure, this can be counterproductive. The church will not own the campaign. "It was time to have an evangelistic campaign again" can be acceptable, too, for it is desirable to have at least one campaign each year.

Question 6

TABLE 4

OBJECTIVES OF THE CAMPAIGN

\begin{tabular}{|c|c|c|}
\hline objectives & $\begin{array}{l}\text { Number of } \\
\text { Responses }\end{array}$ & $\begin{array}{l}\text { Percentage } \\
\text { Campaigns }\end{array}$ \\
\hline
\end{tabular}

To reach more people

To activate the church

17

77

To baptize non-SDAs and SDA-children

20

91

To make the church known

To proclaim the gospel

$8 \quad 36$

15

The activating of the church, which got most of the marks, corresponds with the reviving of the church that was mentioned in question 5. This question seems to indicate that even more than reaching people for Christ, the positive effect on the church itself is aimed at and hoped for. Although that is a valid point, one has to 
ask, if in this case, the effort is still an evangelistic campaign. The evangelistic purpose certainly has to take first place. The rather small percentage of churches which had baptisms as their goal may depend on the nature of the campaign. Usually congregational evangelistic campaigns are concerned with sowing rather than with reaping. They are designed to come in contact with new people or to help Bible study partners to get acquainted with the church. Nevertheless, even under those conditions, the aim must be decisions that lead to baptisms, or the campaign could hardly qualify as evangelistic.

\section{Question 7}

The question concerning the target groups for whom the effort was designed elicited some very interesting responses: Twelve pastors checked "no specific target group" and fifteen marked "all of them" (all people). These two responses go closely with one another. Only twice was "no specific target group" checked without a mark on "all of them (all people)". That is,

seventeen times $(77 \%)$ there was no specific target group to aim at. Nine times an age group was checked (five times youth; twice young couples, once the middle aged, once the elderly). Five times a social class was indicated (once the lower class, four times the middle class). Twice a class with a certain degree of education was noted (once people with elementary-school education, 
once people with lower grade secondary-school education). Four times the target group consisted of people who already had some conriections to SDAs, that is friends and acquaintances; once it was the circle of inactive members, and once people who are interested in religion. The total number of answers given to this question shows some overlapping and some inconsistencies. For example, on one questionnaire there was checked: "no specific target group," "a socio-economic class" ("lower class", "middle class"), "a class having a certain education" ("elementary school," "lower grade secondary school"), and "all of them." In any case the majority of all churches had no target group in mind. This question concerning the target group may have caused some pastors to think. One pastor who checked "no specific target group" and "all of them" made the remark: "Perhaps this is the problem." Another defended himself. He wrote that the church is located in a small town so that it is impossible to choose a target group and that one had to aim at all people. Target group definition is certainly necessary.

\section{Question 8}

Question 8 dealt with the preparation for the campaign. It was subdivided into four sections: (1) preparation of the church, (2) finances, (3) program for the meetings, (4) and preparation of the public. 
TABLE 5

PREPARATION OF THE CHURCH

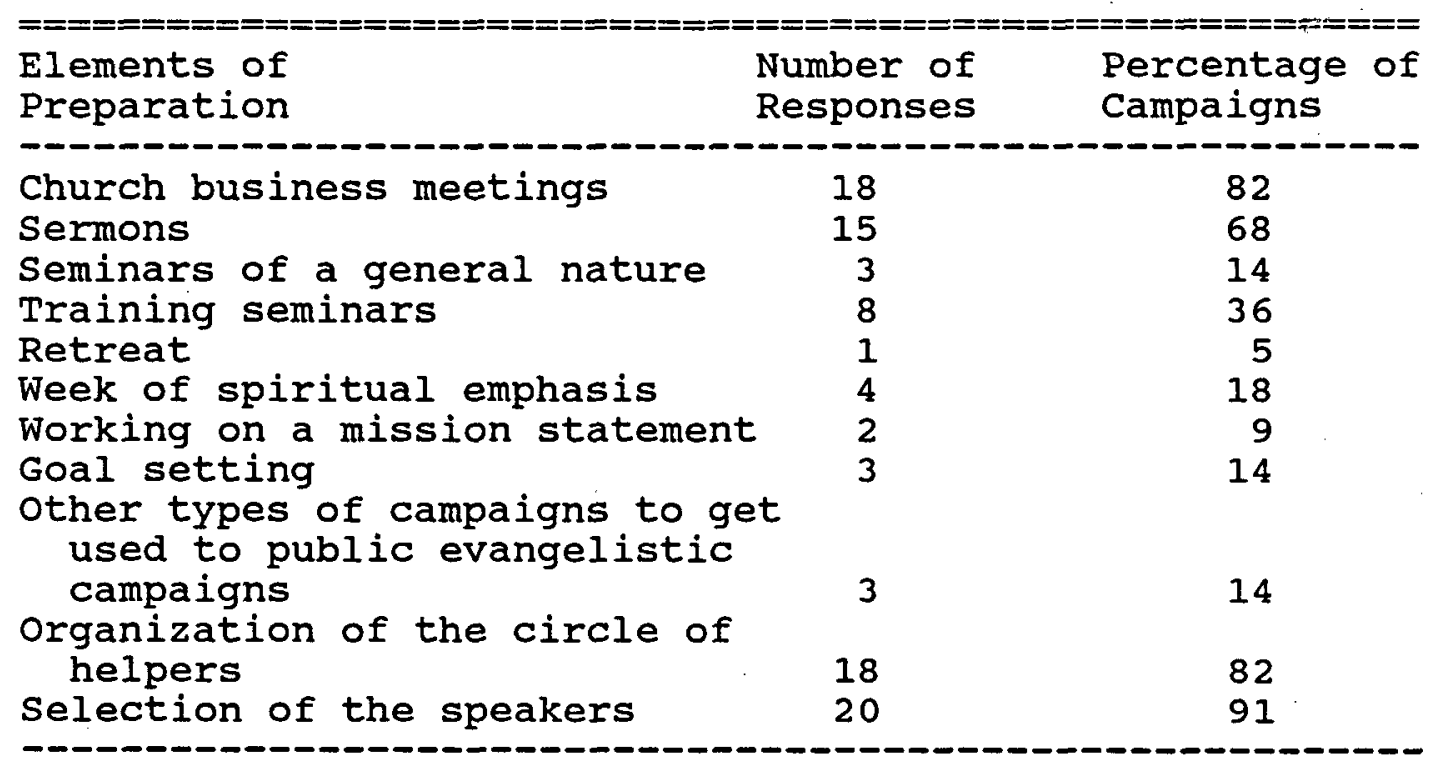

Furthermore, prayer meetings and prayer groups were mentioned once; the preparation of choirs and music ensembles, once; the distribution of lists to the church members to get involved in specific tasks essential for the campaign, twice; and the distribution of lists to the church members to put down the addresses of friends and relatives for whom to pray and/or who were to be invited to the campaign by a letter, twice. The main emphasis in the preparation of the churches consisted of church business meetings, sermons, the selection of the speakers, and the organization of the circles of helpers. Training seminars for the church members were held in one third of the churches. Here is probably an area needing improvement. To send laymen to the platform who have not 
had some exposure to previous public speaking may not be very wise.

By mistake, the items concerning the use of prayer meetings and the starting of small groups were omitted when the original draft of the questionnaire was translated into German. However, there was space to mention additional preparations. Since prayer meetings were reported only once, one can conclude that either there were no prayer meetings at all or that prayer meetings were not regarded as a part of the preparation of the church. The same is true for small groups. The first observation seems to prove true, because the majority of the churches in west Germany do not have prayer meetings at all. The problem is similar with small groups. This again is an area that needs more study.

\section{TABLE 6}

\section{FINANCIAL}

\begin{tabular}{|c|c|c|}
\hline Fiancial Arrangements & $\begin{array}{l}\text { Number of } \\
\text { Responses }\end{array}$ & $\begin{array}{l}\text { Percentage of } \\
\text { Campaigns }\end{array}$ \\
\hline Church pays for own outreach & 9 & 41 \\
\hline Support by local conference & 13 & 59 \\
\hline $\begin{array}{l}\text { Church pays partly for own } \\
\text { outreach }\end{array}$ & 6 & 27 \\
\hline $\begin{array}{l}\text { Fees from the participants } \\
\text { offerings during campaign }\end{array}$ & $\begin{array}{l}3 \\
5\end{array}$ & $\begin{array}{l}14 \\
23\end{array}$ \\
\hline
\end{tabular}

As shown in Table 6, nine of the churches paid for their own outreach programs; thirteen churches asked 
for support from the local conference; six of those that asked for support were financing the campaign at least partly. Thus two-fifths of the churches wanted to take full financial responsibility for their campaign, although it is very easy to get help from the local conference. This fact may indicate that these churches really owned their campaigns. Only three churches asked for fees from the participants and only five took offerings during the campaign. These eight churches that asked the audience for some financial support make up $37 \%$ of the churches. The other churches obviously felt uneasy asking for a fee or having an offering in this type of approach.

TABLE 7

PREPARATION OF PROGRAMS

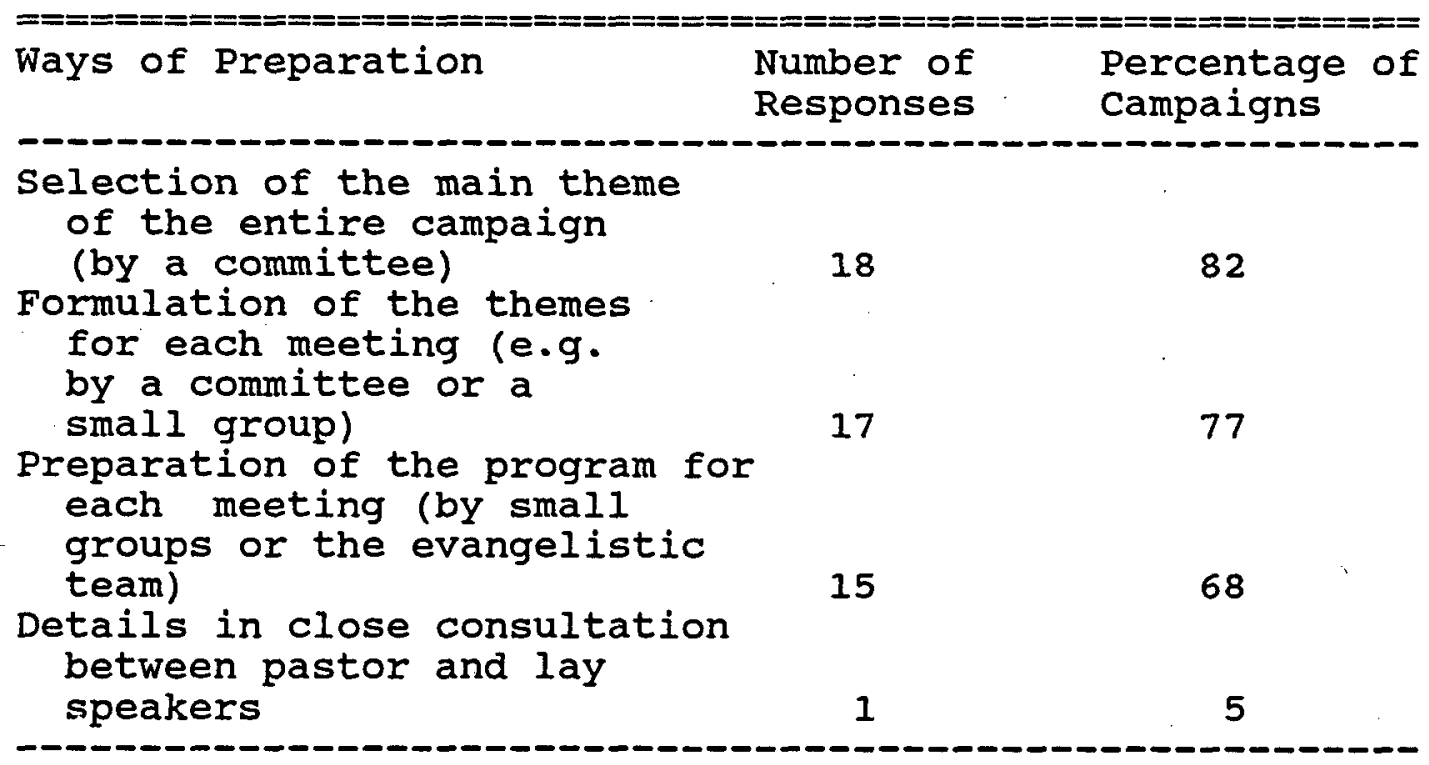


These answers emphasize that a congregational evangelistic campaign is really a group effort. There are not some individuals making decisions, but groups and committees. Some of the twenty-two churches that are reflected by the questionnaires, however, obviously did not use group processes as extensively as possible.

\section{TABLE 8}

\section{PREPARATION OF THE PUBLIC}

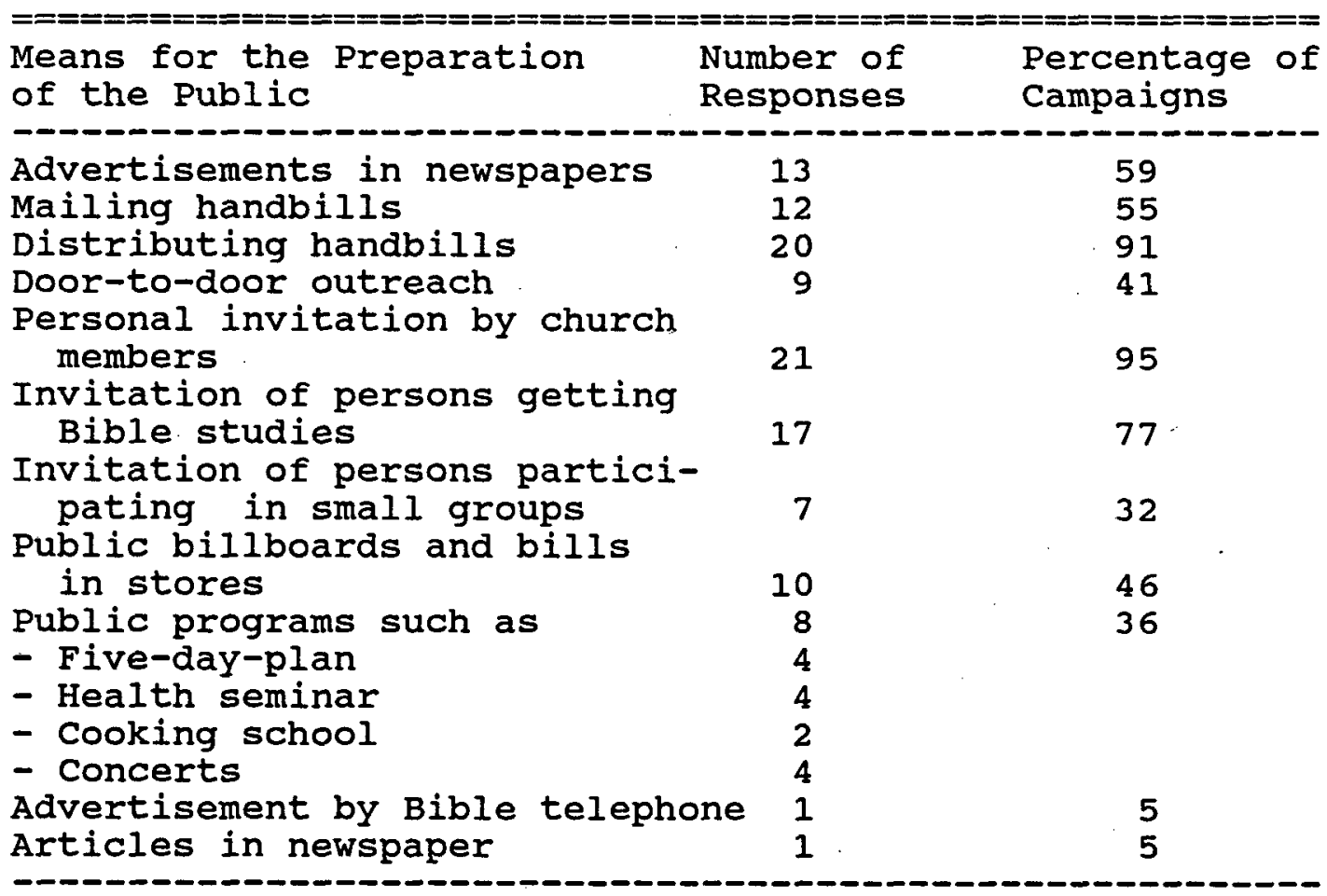

The preparation of the public may vary somewhat from place to place. The cooperation of the entire church is needed with the preparation of the public, for it is the church membership that distributes the handbills and 
invites friends and relatives, and these two items got most of the marks.

\section{Question 9}

Question 9 refers to the implementation and has again four subdivisions. It deals (1) with the elements that structure the meetings, (2) with the public proclamation and the discussions in small circles, (3) the themes of the meetings, and (4) the average number of persons involved in the proclamation from the platform per meeting.

\section{TABLE 9}

ELEMENTS THAT STRUCTURED THE MEETINGS

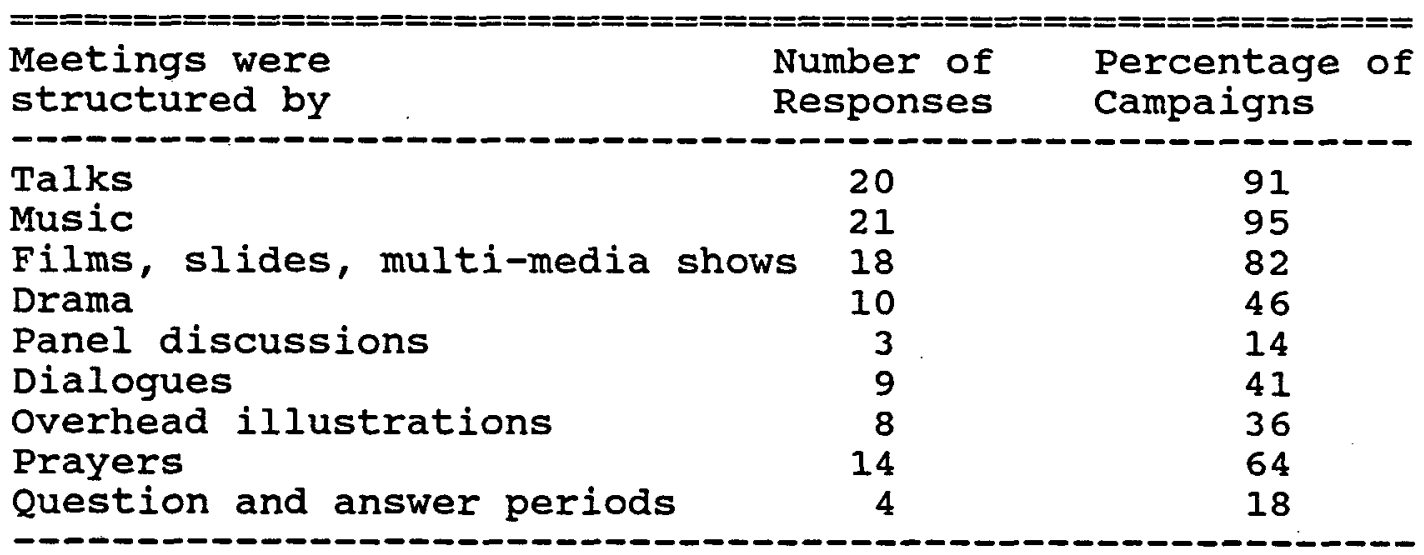

In addition, testimonies and giftbooks were each used twice; discussions with the audience, flannelboard illustrations, quizes, poems and meditations, moderation, and baptismal ceremony are each mentioned once. One could expect that talks, music, and multi-media shows would be 
the most common elements to structure the meetings. On the other hand prayers are used only in about two-third of the campaigns. Why? This may depend on the nature of the topic and the nature of congregational evangelistic campaigns which often try to reach secular men with somewhat secular themes. Under these circumstances a team often may feel it is not free to force prayer upon the audience. However, prayer has its place in most of the campaigns--if not in all--at least after a few meetings have been held. Perhaps one has to be more audacious in this area. It is amazing that the giving of testimonies was mentioned only twice. This is an essential tool to win people to Christ and to cause them to make decisions.

TABLE 10

PROCLAMATION AND DISCUSSION GROUPS

\begin{tabular}{|c|c|c|}
\hline Kind of Meeting & $\begin{array}{l}\text { Number of } \\
\text { Responses }\end{array}$ & $\begin{array}{l}\text { Percentage of } \\
\text { Campaigns }\end{array}$ \\
\hline $\begin{array}{l}\text { Public proclamation only } \\
\text { Public proclamation and } \\
\text { discussions in small circles } \\
\text { These } \\
\text { - met in the same room } \\
\text { - met in another room } \\
\text { - had soft drinks and cookies } \\
\text { - had no soft drinks and } \\
\text { - cookies } \\
\text { - were formal } \\
\text { - were informal }\end{array}$ & $\begin{array}{r}14 \\
10 \\
4 \\
10 \\
\\
2 \\
1 \\
13\end{array}$ & 23 \\
\hline
\end{tabular}

In three-fourth of all campaigns the public proclamation plus the conversation in small groups was 
favored. So an opportunity was provided to contact the guests in a natural way and to allow them to voice their opinions, to ask questions, and to interact with one another and with church members. This seems to be more and more important. The question about soft drinks and cookies was not answered twice. Nevertheless, a clear picture emerges. The small circles were mainly informal groups which allowed the free discussion of questions. One pastor noted that their meetings consisted of three parts, but in all three parts talks predominated. Another minister who checked "public proclamation only" remarked that the guests had the opportunity to talk to the pastor after the meeting was over. This approach, however, seems to be more clergy-centered than laitycentered.

TABLE 11

THEMES OF THE MEETINGS

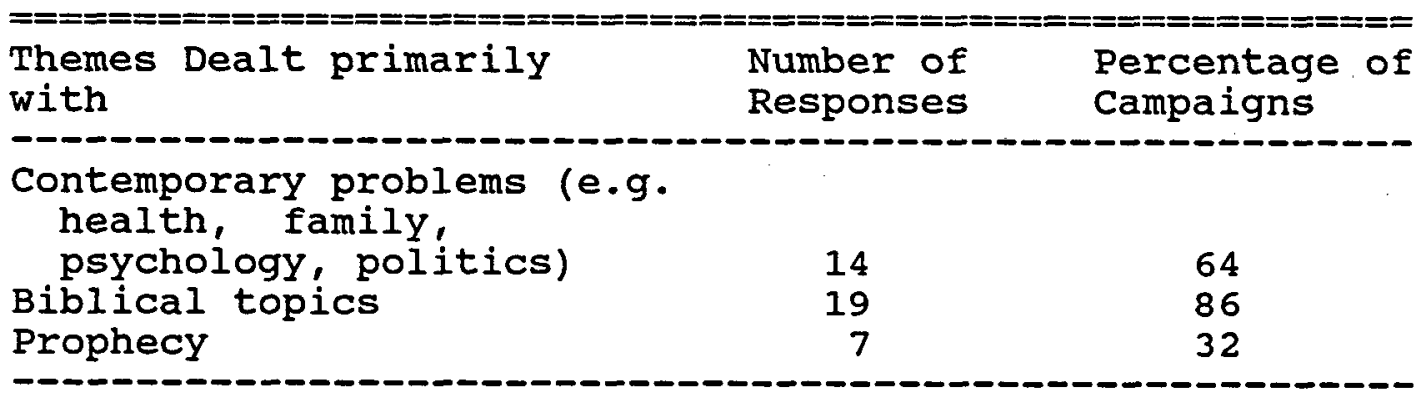

The Bible is the center of the meetings. However, to reach the unchurched one often has to talk about contemporary problems and then relate them to 
Christianity. Prophecy may be a good main theme, too. This depends on the target group.

TABLE 12

NUMBER OF SPEAKERS PER MEETING

\begin{tabular}{|c|c|c|}
\hline $\begin{array}{l}\text { Average Number of Speakers } \\
\text { per Meeting }\end{array}$ & $\begin{array}{l}\text { Number of } \\
\text { Responses }\end{array}$ & $\begin{array}{l}\text { Percentage of } \\
\text { Campaigns }\end{array}$ \\
\hline 1 person & 2 & 9 \\
\hline 2 persons & 3 & 14 \\
\hline $3-5$ persons & 13 & 59 \\
\hline More than 5 persons & 4 & 18 \\
\hline
\end{tabular}

When only one person proclaims the gospel or gives talks from the platform it matches my definition of a "lay evangelistic campaign" but not so much a "congregational evangelistic campaign." Even to work with two persons tends to move in the direction of lay evangelistic outreach. More than five persons per evening may be too much; three to five persons seems to be the best solution, and in practice this category forms the vast majority.

\section{Question 10}

Several methods can be used in the follow-up of a campaign. Table 13 points to some of them. Methods which were used most frequently were: (1) visits to the guests in their homes, (2) Bible studies with the guests of the campaign, (3) invitations to the worship service, and (4) invitation to other public programs. Obviously, these 
are the most important methods of follow-up. However, others should not be neglected, for example, invitations to other types of evangelistic campaigns. Hospitality and friendship should also be stressed suffienctly.

TABLE 13

FOLLOW-UP

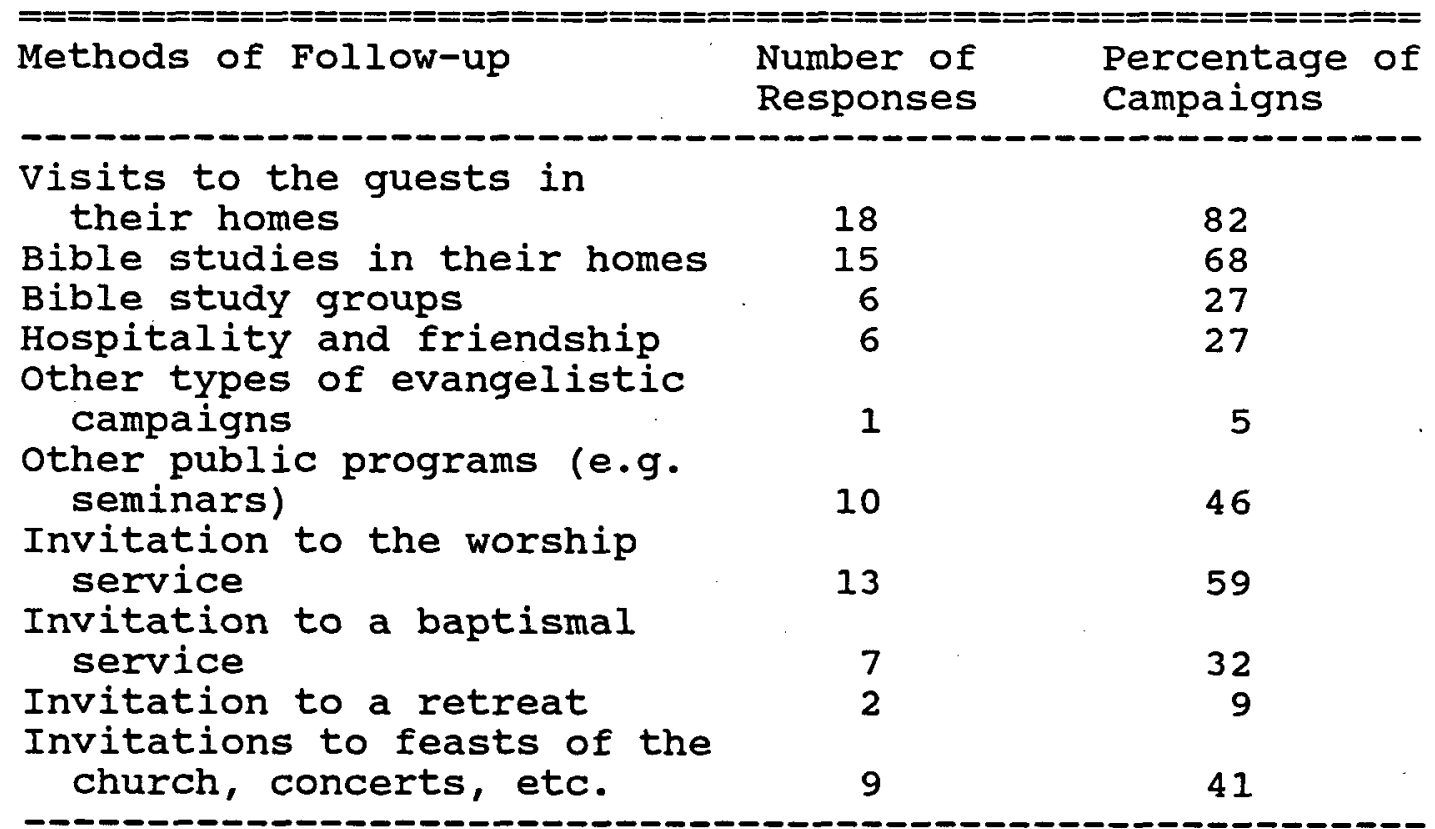

In addition, one church used small group meetings as a follow-up device. Here again the involvement of a large segment of the church and the personal contact with the guests are very important.

\section{Question 11}

Question no.11 dealt with the participation of the church in (1) preparation, (2) implementation, and (3) follow-up. 
TABLE 14

THE PARTICIPATION OF THE CHURCH

\begin{tabular}{|c|c|c|c|}
\hline $\begin{array}{l}\text { Area of } \\
\text { Participation }\end{array}$ & $\begin{array}{l}\text { Maximum Percentage } \\
\text { of Member } \\
\text { Participation }\end{array}$ & $\begin{array}{l}\text { Number } \\
\text { of } \\
\text { Responses }\end{array}$ & $\begin{array}{l}\text { Percentage } \\
\text { of } \\
\text { Churches }\end{array}$ \\
\hline Preparation & $\begin{array}{r}5 \\
10 \\
20 \\
30 \\
50 \\
80\end{array}$ & $\begin{array}{l}1 \\
3 \\
5 \\
7 \\
5 \\
1\end{array}$ & $\begin{array}{r}4 \\
14 \\
23 \\
32 \\
23 \\
4\end{array}$ \\
\hline Implementation & $\begin{array}{r}5 \\
10 \\
20 \\
30 \\
50 \\
80\end{array}$ & $\begin{array}{l}1 \\
1 \\
3 \\
2 \\
8 \\
7\end{array}$ & $\begin{array}{r}5 \\
5 \\
13 \\
9 \\
36 \\
32\end{array}$ \\
\hline Follow-up & $\begin{array}{r}5 \\
10 \\
20 \\
30 \\
50 \\
80\end{array}$ & $\begin{array}{l}7 \\
6 \\
6 \\
1 \\
1 \\
0\end{array}$ & $\begin{array}{r}33 \\
28 \\
29 \\
5 \\
5 \\
0\end{array}$ \\
\hline
\end{tabular}

In comparing the three tables one recognizes that in the preparation of the campaign the member participation of most of the churches (78\%) lay in the 20-50 percent range. In the implementation, however, the member participation of most of the churches (68\%) was in the 50-80 percent category. It dropped significantly in the follow-up. Whereas only one church ranged in the 5 percent area in the preparation and implementation of the campaign, seven churches $(32 \%)$ were in the 5 percent category during the follow-up. The member participation 
of most of the churches (90\%) lay in the $5-30$ percent area. If one takes a scale from 1 to 7 and gives 1 point to the participation of up to 5 percent of the church members and 7 points to the participation of more than 80 percent of the church members, the scores for all twenty-two churches would look like this:

$$
\begin{array}{ll}
\text { Participation in the preparation: } & 3.7 \\
\text { Participation in the implementation: } & 4.6 \\
\text { Participation in the follow-up: } & 2.2
\end{array}
$$

This makes it clear that the weakest point in the campaigns for member participation is the follow-up. Participation in the preparation and implementation is quite good, probably higher than with a traditional evangelistic campaign--especially in the matter of preparation. But the follow-up, similar to traditional campaigns, is the problem. The follow-up needs special attention. Training seminars should cover not only the presentation of the message, but particularly the follow-up.

How does the size of the church correspond with participation in the campaign? Using the same scales, table 14 shows the participation scores. Churches with up to 200 members and more than 200 members are rather similar concerning participation. However, a significant decrease of participation occurs when one moves from smaller to larger churches. 
TABLE 15

MEMBERS PARTICIPATION IN EFFORTS

\begin{tabular}{|c|c|c|c|c|}
\hline $\begin{array}{l}\text { size of } \\
\text { church }\end{array}$ & $\begin{array}{l}\text { Preparation } \\
\text { Score }\end{array}$ & $\begin{array}{l}\text { Implementation } \\
\text { Score }\end{array}$ & $\begin{array}{l}\text { Follow-up } \\
\text { Score }\end{array}$ & $\begin{array}{l}\text { Mean } \\
\text { Score }\end{array}$ \\
\hline 0 to 50 & & & & \\
\hline members & 4.7 & 5.7 & 3.0 & 4.5 \\
\hline $\begin{array}{l}50 \text { to } 100 \\
\text { members }\end{array}$ & 4.1 & 4.9 & 2.6 & 3.9 \\
\hline $\begin{array}{l}100 \text { to } 200 \\
\text { members }\end{array}$ & 3.0 & 4.4 & 1.6 & 3.0 \\
\hline $\begin{array}{l}\text { more than } \\
200 \text { members }\end{array}$ & 3.3 & 4.3 & 1.7 & 3.1 \\
\hline
\end{tabular}

Reasons for the decrease of participation when one moves from smaller to larger churches may be: (1) the anonymity of larger churches, (2) goals are not owned to the same degree in larger churches as they are in smaller churches, and (3) passivity tends to prevail in larger churches more easily than in smaller churches. One can act according to the motto: "It works without me, too." But larger churches do have several advantages compared to small ones, especially a larger reservoir of people who are able to speak publicly. 1 They may also conduct a larger number of campaigns than do small churches. 2

${ }^{1}$ see schaller, Growing Plans, who in the first three chapters of his book talks about the growth of small churches, of middle-sized churches, and of large churches.

${ }^{2}$ see question 4 of this questionnaire. 
Question 12

Question 12 had three subdivisions. It asked about the number of visitors.

\section{TABLE 16}

NUMBER OF VISITORS

\begin{tabular}{|c|c|c|c|}
\hline Question & $\begin{array}{l}\text { Maximum Number } \\
\text { of Visitors }\end{array}$ & $\begin{array}{l}\text { Number of } \\
\text { Responses }\end{array}$ & $\begin{array}{l}\text { Percentage of } \\
\text { Campaigns }\end{array}$ \\
\hline $\begin{array}{l}\text { Highest number } \\
\text { of visitors at } \\
\text { one meeting }{ }^{1}\end{array}$ & $\begin{array}{ll} & 5 \\
10 & \\
20 & \\
50 & \\
\text { more than } 50\end{array}$ & $\begin{array}{r}1 \\
4 \\
11 \\
4 \\
1\end{array}$ & $\begin{array}{r}5 \\
18 \\
50 \\
18 \\
5\end{array}$ \\
\hline $\begin{array}{l}\text { Average number } \\
\text { of visitors } \\
\text { per meeting }\end{array}$ & $\begin{array}{cl} & 5 \\
10 & \\
20 & \\
50 & \\
\text { more than } 50\end{array}$ & $\begin{array}{r}5 \\
11 \\
4 \\
2 \\
0\end{array}$ & $\begin{array}{r}23 \\
50 \\
18 \\
9 \\
0\end{array}$ \\
\hline $\begin{array}{l}\text { Total number } \\
\text { of visitors in } \\
\text { the campaign }\end{array}$ & $\begin{array}{r}10 \\
20 \\
30 \\
50 \\
70 \\
100 \\
150\end{array}$ & $\begin{array}{l}1 \\
6 \\
2 \\
2 \\
5 \\
3 \\
1\end{array}$ & $\begin{array}{r}5 \\
27 \\
9 \\
9 \\
23 \\
14 \\
43\end{array}$ \\
\hline
\end{tabular}

Looking at all these figures one perceives that there are not multitudes that are reached! Usually one can expect up to twenty guests as the highest attendance kept.

Ionce no answer was given because no records were

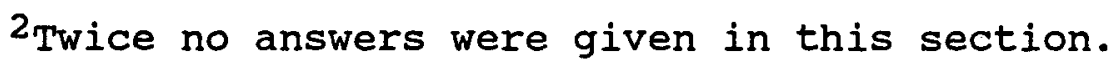

${ }^{3}$ It seems that this figure is not correct, for the pastor reports on a campaign with six to ten meetings and an average attendance of ten guests per meeting. 
111

per evening. The average per evening is up to ten visitors. The average of all the guests reached per campaign is about forty-six. That seems to be disappointing. However, when one looks at the report of the south German Union Conference Session of Seventh-day Adventists for the years 1977 to 1981, one notes that in this period 262 evangelistic campaigns held by pastors ${ }^{1}$ in this field drew 7,964 non-SDAs that is about 30 visitors per campaign. 2 Two professional evangelists were busy during this period. One evangelist reported that the number of addresses he got with his campaigns averaged forty-seven per campaign. 3 This is compared with the average number of guests per congregational evangelistic campaign of about 46.4 This information seems to indicate that it is

1 Perhaps congregational evangelistic campaigns are included. The statistical report does not indicate what type of campaign was held. See Konferenzbericht über die Jahre 1977 - 1981. Vorgelegt zur Abgeordnetenversammlung des süddeutschen Verbandes am 20. Mai 1982 in stuttgart (stuttgart: Gemeinschaft der Siebenten-Tags-Adventisten, Süddeutscher Verband, 1982), p. 24 .

2 These figures do not include one campaign by an American evangelist ( $R$. Lehnhoff), five by officers of the Euro-Africa-Division, two conducted by a teacher, and several campaigns by two conference evangelists. However, there are no reports on these campaigns with the exception of the campaigns of the evangelists. See ibid., pp. 25-27.

${ }^{3}$ see ibid., p. 26.

${ }^{4}$ The ratio between the number of meetings and the number of baptisms and decisions to be baptized is difficult to establish. The second evangelist in south Germany during this period reported sixteen baptisms with 
quite difficult in West Germany to draw large numbers of people in evangelistic campaigns and that there is not a big difference between campaigns conducted by professional evangelists and campaigns conducted by local churches, even though professionals use more intensive advertising than churches do.

TABLE 17

SCORES REVEALING GUEST ATTENDANCE

\begin{tabular}{|c|c|c|c|c|}
\hline $\begin{array}{l}\text { Size } \\
\text { of } \\
\text { church }\end{array}$ & $\begin{array}{l}\text { Highest Number } \\
\text { at one meeting }\end{array}$ & $\begin{array}{l}\text { Average Number } \\
\text { per meeting }\end{array}$ & $\begin{array}{l}\text { Total Number } \\
\text { in campaign }\end{array}$ & Mean \\
\hline $\begin{array}{l}0 \text { to } 5 \\
\text { members }\end{array}$ & 3.0 & 1.7 & 3.7 & 2.8 \\
\hline $\begin{array}{l}50 \text { to } \\
\text { members }\end{array}$ & $\begin{array}{l}100 \\
s\end{array}$ & 2.0 & 4.1 & 3.0 \\
\hline $\begin{array}{l}100 \text { to } \\
\text { members }\end{array}$ & $s^{200}$ & 2.2 & 4.2 & 3.1 \\
\hline $\begin{array}{l}\text { ore th } \\
\text { oo men }\end{array}$ & $\begin{array}{l}\text { han } \\
\text { mb. }\end{array}$ & 2.4 & 4.6 & 3.3 \\
\hline
\end{tabular}

A note on the relationship between the size of the churches and the number of guests that attended the particular campaigns. If one takes a scale from 1 to 9 and gives 1 point for up to 5 guests and 9 points for

193 meetings (in four campaigns). See ibid., p. 27. The questionnaires on congregational evangelistic campaigns report on approximately 160 meetings (in twenty-two campaigns). Eight times "decisions to be baptized" was checked,but one mark can stand for more than one decision or baptism. 
more than 200 guests, then one gets the figures of table 17. In each type of church the scores relating to the highest number of non-SDAs attending one meeting were the same. The average number of guests and the total number of guests, however, grew with the increasing number of church members.

Question 13

TABLE 18

METHODS BY WHICH NON-SDAS WERE ATTRACTED

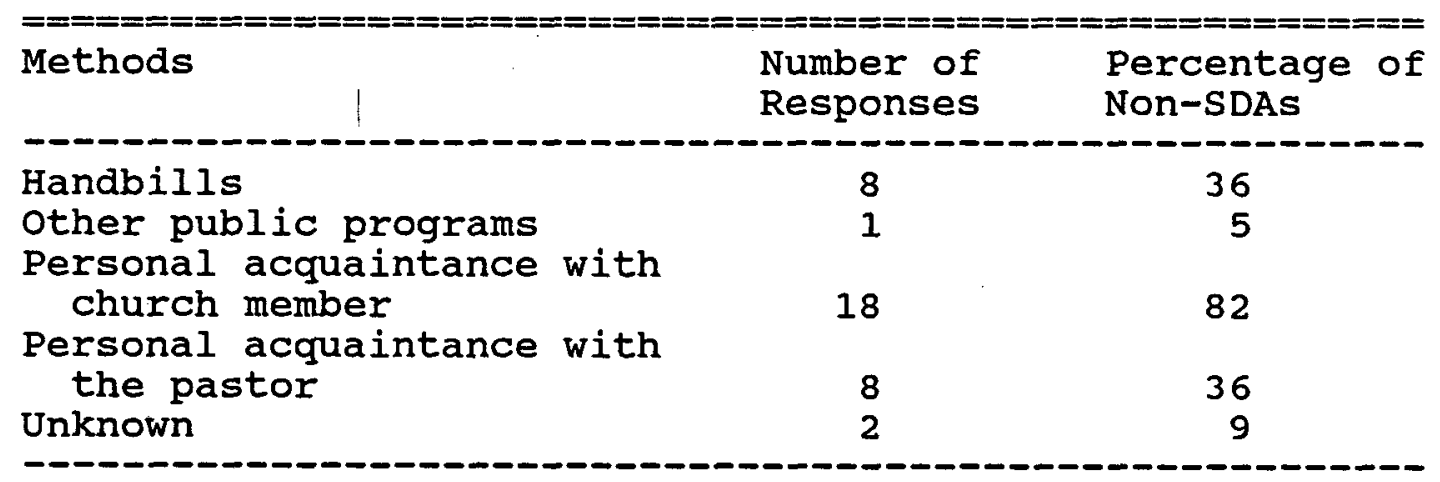

These answers clearly stress the importance of friendship ties between church members and Non-SDAs. Friendship ties are the main source for drawing people to the campaigns.

\section{Questions 14}

Responses concerning positive side effects of congregational evangelistic campaigns on churches are listed in table 19. Such campaigns mainly seem to foster fellowship among church members. Often they also seem to 
increase the worship service attendance of church members.

TABLE 19

POSITIVE EFFECTS ON CHURCHES

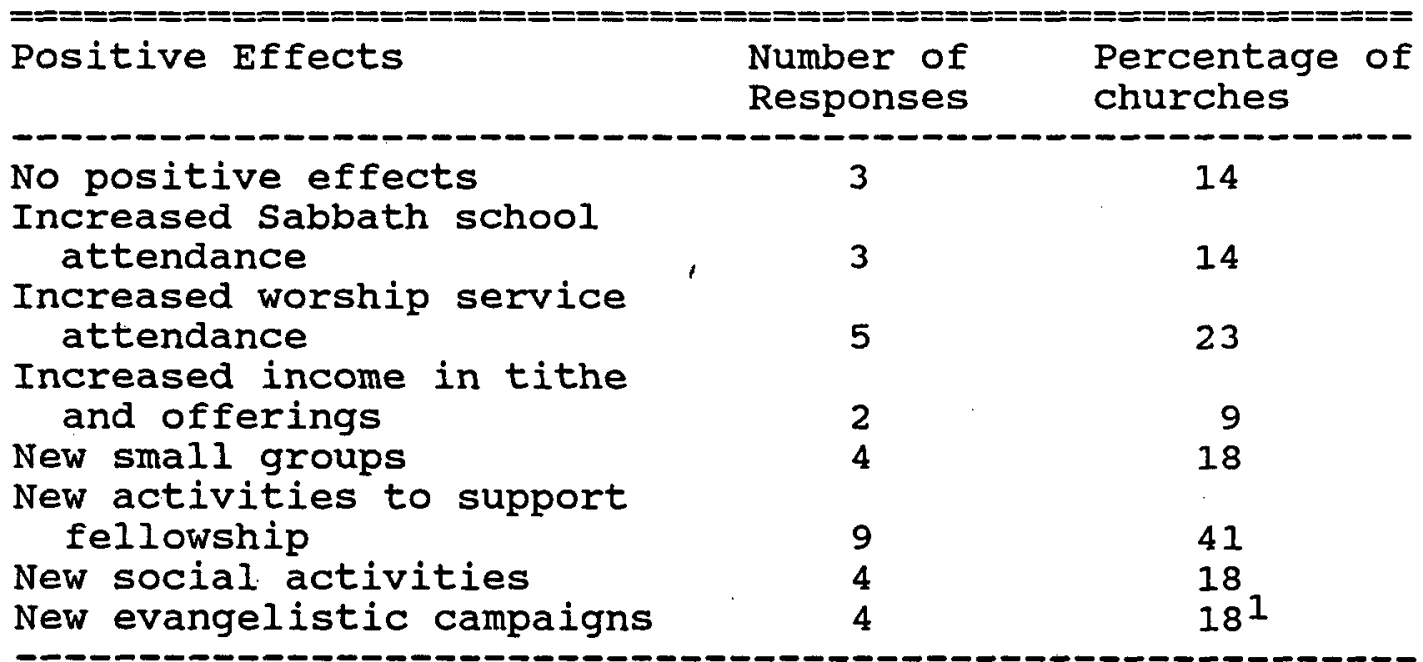

Question 15

Beside the positive effects on churches, congregational evangelistic campaigns also have positive effects on non-SDAs. If no positive effects would occur congregational evangelistic campaigns might need to be abandoned. The questionnaires especially indicate deeper relationships to SDAs and attendance at worship services as the most important positive effects of such campaigns on nOn-SDAs.

${ }^{1}$ In addition, one response said "not measurable, but positive"; one said it calmed things down after quarrels; and another indicated a new joyfulness. So congregational evangelistic campaigns also have positive side effects for the churches. 
TABLE 20

POSITIVE EFFECTS ON NON-SDAS

\begin{tabular}{|c|c|c|}
\hline Positive Effects & $\begin{array}{l}\text { Number of } \\
\text { Responses }\end{array}$ & $\begin{array}{l}\text { Percentage } \\
\text { of Visitors }\end{array}$ \\
\hline $\begin{array}{l}\text { No positive effects } \\
\text { New relationships to SDAs } \\
\text { Deeper relationships to SDAs } \\
\text { Bible studies in homes possibl } \\
\text { Bible study groups joined } \\
\text { Attendance at worship service } \\
\text { Attendance at other programs } \\
\text { Decisions to be baptized }\end{array}$ & $\begin{array}{r}1 \\
9 \\
14 \\
11 \\
4 \\
14 \\
9 \\
8\end{array}$ & $\begin{array}{l}5 \\
41 \\
64 \\
50 \\
18 \\
64 \\
41 \\
36^{1}\end{array}$ \\
\hline
\end{tabular}

Questions 16 and 17

These questions dealt with the opinion of church members and pastors about congregational campaigns.

TABLE 21

ATTITUDE TOWARDS CONGREGATIONAL CAMPAIGNS

\begin{tabular}{|c|c|c|c|}
\hline Groups & Opinion & $\begin{array}{l}\text { Number of } \\
\text { Responses }\end{array}$ & $\begin{array}{l}\text { Percentage of } \\
\text { groups }\end{array}$ \\
\hline $\begin{array}{l}\text { Church } \\
\text { members }\end{array}$ & $\begin{array}{l}\text { very enthusiastic } \\
\text { mildly enthusiastic } \\
\text { neutral } \\
\text { discontented }\end{array}$ & $\begin{array}{r}3 \\
15 \\
3 \\
1\end{array}$ & $\begin{array}{r}14 \\
68 \\
14 \\
4\end{array}$ \\
\hline Pastors & $\begin{array}{l}\text { very enthusiastic } \\
\text { mildly enthusiastic } \\
\text { neutral } \\
\text { discontented } \\
\text { strictly against it }\end{array}$ & $\begin{array}{r}7 \\
14 \\
0 \\
1 \\
0\end{array}$ & $\begin{array}{r}32 \\
64 \\
0 \\
4 \\
0\end{array}$ \\
\hline
\end{tabular}

IIn addition, two remarks were made. One pastor mentioned that the campaign was held only recently so that nothing could be said about its effects. Another wrote: "Certainly something happened. But is it possible, to trace back each decision on only one campaign?" 
Not even one church was entirely opposed to congregational evangelistic campaigns. This seems to indicate that the large majority of the churches are in favor of such campaigns.

Pastors who were involved in congregational evangelistic campaigns favor this type of effort even more than church members do. 1

\section{Question 18}

This positive evaluation by the pastors is also seen with question no. 18: "What do you think about congregational evangelistic campaigns as compared to traditional efforts?"

TABLE 22

COMPARISON TO TRADITIONAL CAMPAIGNS

\begin{tabular}{|c|c|c|}
\hline Evaluation & $\begin{array}{l}\text { Number of } \\
\text { Responses }\end{array}$ & $\begin{array}{l}\text { Percentage of } \\
\text { Pastors }\end{array}$ \\
\hline Much more successful & 1 & 4 \\
\hline More successful & 14 & 64 \\
\hline Similar & 3 & 14 \\
\hline Less successful & 1 & 4 \\
\hline Much less successful & $\overline{0}$ & 0 \\
\hline
\end{tabular}

Three pastors did not mark any box (14\%), though two of them made remarks that go into the direction of "more successful." Again a large majority thinks that

1 on a scale from 1 ("strictly against it") to 5 ("very enthusiastic) the pastors get a score of 4.2 points, whereas the church gets one of 3.9 points. 
this type of campaign is more successful than a traditional one $(77 \%)$. Whether or not this perception is correct is another question. 1 In any case, pastors do have this impression, and being enthusiastic about something is certainly a strong motivator, so good results may follow. ${ }^{2}$ All pastors who returned the questionnaire are willing to lead out in such campaign (100\%).

Question 19

Also noted on the questionnaire were weaknesses that might be evident in the campaigns that were held. These were considered in three categories.

question:

lUnfortunately there were not sufficient dates to compare the two types of campaigns in West Germany. It seems, however, that the results are similar. See above.

${ }^{2}$ Several remarks were made in regard to this

Congregational evangelistic campaigns are less successful

- if there is not good coordination and if overlapping occurs. Laymen usually are not used to speaking publicly and do not have much experience in evangelism.

- if there is no continuity of congregational campaigns over years.

Congregational evangelistic campaigns are more successful, because

- the church uses its spiritual gifts and recognizes its mandate

- there is an open atmosphere

- the church is more active

- guests feel at home

- the church itself is in the center and not a single person

- contacts are made more easily and are more durable

- it is in its form more up-to-date.

old thought patterns are hindering church growth.

Both types of evangelistic campaigns are important and should be used by turns. 
1. Weaknesses in the preparation: six respondents made no remark in this area. However, four of these six questionnaires pointed to weaknesses in implementation and/or follow-up. One person did not detect weaknesses that are worth mentioning. That means, 32 percent of the pastors obviously did not perceive weaknesses with the preparation of the campaign. One person checked this point but gave no information. So, of fourteen questionnaires $(64 \%)$ with twenty comments, six point to weaknesses in the area of public relations. Another six mention weaknesses in the area of planning, five deal with a lack of motivation, one mentions problems with the dynamics of the groups, one talks about psychological problems, for example, fear, one points to the fact that a lot of time is spent for this type of campaign. The main weaknesses in the preparation were public relations, planning, and motivation.

2. Weaknesses in the implementation: Again seven pastors did not list any weaknesses (32\%), two of whom saw problems, but did not mention them explicitly. The remaining thirteen questionnaires contain fourteen comments. Nine talk about problems with the performance, two about a lack of motivation, two about problems with the small discussion groups, and one about a lack of personnel. The main weakness in the implementation was performance. 
3. Weaknesses in the follow-up: Five pastors did not put down any weakness (23\%). The seventeen remaining questionnaires had eighteen comments. This area seems to be the most sensitive as participation in the follow-up (above) has indicated.1 Problems are seen with the participation of the church members in the follow-up (9 times), the training of the church members ( 3 times), the motivation ( 2 times), the lack of interest with the guests ( 2 times), the planning process ( 1 time), and the transfer of the pastor to another church ( 1 time). The main weakness in the follow-up is participation of the church members.

Question 20

Question 20 asked the pastors: "What would you do differently if you were to participate in another congregational evangelistic campaign?" Eighteen questionnaires had responses to this question; thirty-three comments were made. They include:

- Extension and improvement of the preparation phase

- Goal setting and planning

- Coordination

- Training the church members

- Public relations

- Public hall for meetings

${ }^{1}$ See question $11 \mathrm{c}$. 
- Prayer meetings

- Topics that are up-to-date (marriage, family, faith, etc.) and very practical

- Choosing target groups

The answers summarize in this way: preparation should be improved (23 times), implementation (5 times), and follow-up ( 5 times).

\section{Report on the Interviews}

Interviews were held with five persons--three pastors and two local head-elders. All had participated in several congregational evangelistic campaigns. They were asked five questions to supply additional information on this type of campaign. 1

The first question dealt with the problem of reaching secular man and the contribution congregational evangelistic campaigns are able to make. All five persons had difficulties answering this question. Their answers included: This type of evangelism is strong in building personal relationships between guests and church members. These relationships are stronger than those between guests and pastors. Laymen have a similar background and are accepted more easily than pastors. People may attend the meeting even if they are not interested spiritually. The meetings should center around the needs of secular

$1_{\text {See Appendix } 3 .}$ 
man. There is a broad spectrum of topics and those should be used to reach people where they are. Congregational. evangelistic campaigns have to be part of a greater concept and plan. ${ }^{1}$ When people are reached they must be carried on by other means. The church itself is activated and identifies with "its" campaign, thereby an atmosphere is created that is open to welcome and to accept guests. Secular man is reached on the social level.

The second question asked: "What do you think about the assumption that congregational evangelistic campaigns are less threatening to guests than traditional ones are?" Almost everyone agreed with this assumption. The congregational campaign is on a level that is interesting for the people. The topics are not heavily theological and deal more extensively with the every-day life, for example, with health. There exists a direct personal contact between the speakers and the audience because of the small groups. Often the guests are already participants of other small groups. They already know some persons that attend the campaign. All of this helps to reduce fear and prejudices which hinder people from coming. Visitors are not afraid of being taken by surprise. several years.

${ }^{1}$ programs and action plans should be laid for 
What about using public buildings instead of church buildings? One pastor prefers church buildings. He argues that usually the gliests are already in contact with church members, so it is not a big problem for them to come to an ecclesiastical building. There are no prejudices. Furthermore, the SDA church is in the center right from the beginning. This alleviates the problem of starting one place and then bringing the people into the church building. The four other respondents have a different point of view: Public halls have advantages because of the prevailing philosophy of secularism in society and the indifference to religion--thereby also the aversion to church buildings. On the other hand, it is important to develop a perspective of going to the people rather than expecting people to come to the church. The problem with public halls concerns (I) the church members who are afraid to speak in an unknown environment and (2) the finances.

"At what point is it best to start praying publicly?" One person said that it depends on the situation. Sometimes it is better not to have prayer before the second or third evening. Secular man has to be prepared for public prayer. Others would start on the first evening. They believe campaigns should never be held without public prayer right from the beginning. Prayer is part of the Christian life. It is, however, 
important to use forms and vocabulary that are acceptable to secular man. It is also essential to announce the prayer and to explain it. Visitors should not be shocked by a sudden prayer; on the other hand, one should not wait too long to introduce prayer. Prayers should use up-to-date language and should be short and without clichés. They should be offered naturally and without fear. Guests sense when someone feels uneasy with prayer. one person suggested prayers at the beginning and the end of each presentation, others prefer to have it only at the end.

The last question referred to the room for the small discussion groups. Opinions vary whether to have small groups sitting around tables right from the beginning of the meeting and staying in the same room, or whether to invite the audience to come to another room to form small discussion groups after the presentation is over. Some think it would be better to have the audience already sitting in semicircles at the beginning of the meeting, because the conversation can start more spontaneously. Furthermore, people will not leave as easily, overhead transparencies containing some questions can guide the discussions, Bibles, scratch paper, pens, and handouts can be placed on the tables before the meeting 
starts, and the leaders of the group discussions can already be seated within the semicircle ${ }^{1}$.

One person mentioned that these small groups should not meet in the sanctuary. If the program is delivered in the sanctuary, the groups should meet in another room. But even if it were possible to stay in the same room all the time, there are some arguments for moving to another one. If the audience is seated around tables all the time, there is the chance of more disturbances and more restlessness; speakers are more easily distracted; and guests may feel forced to participate in the small groups. This is avoided if groups move to another room. In addition, the atmosphere for the groups is characterized by an even more open style.

There is the danger that the conversation will not stay with the topic of the presentation and that it may be hard to start the discussion. In any case, it is important that in congregational evangelistic campaigns people are at ease and make contact with SDAs. One pastor holds that congregational evangelistic campaigns aim mainly at making and cultivating contacts; traditional campaigns mainly aim at gathering in the harvest.

${ }^{1}$ These leaders have to be well-trained persons. They must have good questions to lead the conversation. The effectiveness of the campaign depends to a large degree on these persons. It is also important how well the transition from the presentation to the group experience is done. 
Conclusions

Strengths of congregational evangelistic campaigns

From the questionnaires and the interviews the following picture emerges:

1. Pastors and churches seem to think positively about congregational evangelistic campaigns. This is very important for if these groups abhorred this type of effort, little could be achieved. To own an idea is essential to getting good results. Even if one type of campaign should be better than another, the second one could be more effective if the people felt they owned it and worked with it, especially in the case that they do not like the first approach.

2. In congregational evangelistic campaigns the more open style, which may be less threatening, is preferred. The topics often deal with problems that arise in every-day life. Usually doctrines are not very heavily discussed, although doctrines would certainly need to have their place in the campaign. Witnessing plays an important role and this may be quite attractive to secular man and his needs.

3. An important factor is the building of relationships. In the first place, laymen proclaim the message. Guests may identify with laymen more easily than with clergymen; guests often feel that clerymen do not participate in their every-day problems as laymen do. 
Thus, a more intensive relationship can be established. Secondly, small groups are established for discussion. This enables the visitor to come in touch with more than one church member. He may start to build a circle of friends. He may sense the warmth and acceptance of a small group.

4. The church itself is activated. A high percentage of church members get involved in this type of campaign. Laymen may recognize their responsibility to proclaim the gospel. They notice that they themselves, not merely the pastor, are important. They may even start to plan the next campaign when the first one is just barely over.

In other words, the congregational evangelistic campaign has very positive effects on non-SDAs and on church members alike--in the opinion of the pastors and church elders that responded to the questionnaires and to the interviews.

Weaknesses of congregational

evangelistic campaigns

However, one does perceive some weaknesses in the congregational evangelism as reported by the questionnaire responses:

1. Congregational evangelistic campaigns are usually short-term campaigns held in the church building. This may be an obstacle for secular man who is 
indifferent in regard to God and the church. Church members may use only their own buildings because they fear being exposed more intensively to the public. They also fear spending too much money especially for something that may not work.

2. Congregational evangelistic campaigns tend to be less goal oriented than traditional ones. The danger exists that the church members are content to see some guests and forget to call on people to make decisions and be baptized. Oftentimes no target group is chosen to aim at.

3. Although there are weaknesses in the preparation (advertising, planning, motivation) and in the implementation (presentation of the message), the greatest problem seems to be the follow-up. The participation of church members in this area is very weak.

Every campaign, when carefully analyzed, has its weaknesses. The weaknesses mentioned above are significant, but they can be remedied. Training seminars on the planning process, on the presentation of the message, and on the follow-up should be held before the actual campaign starts. These are necessary to eliminate the weak points. Congregational evangelistic campaigns seem to have great value in spite of the weaknesses, but the weaknesses should be eradicated. 
A MODEL FOR CONGREGATIONAL EVANGELISTIC CAMPAIGNS IN WEST GERMANY

\section{Variables in Congregational Evangelistic Campaigns}

Before a model for congregational evangelistic campaigns is described, variables must be mentioned. This may help one to recognize that a model needs to be adapted to the local situation and cannot be duplicated in each detail. A model serves to provide a broad outline and to give some essential ideas as to how a congregational evangelistic campaign can work and can be effective.

There are many variables in different areas, several of which are indicated below. A classification may include: (1) variables in regard to the church, (2) variables in regard to the pastor, (3) variables in regard to the prospective audience, and (4) variables in regard to the campaign. Some variables cannot be influenced; one has to work with them. Others can be influenced--sometimes rather easily. Four categories of variables are considered here.

1. Variables in regard to the church - Size of the church 
- Education of the church members

- Social-economic level of the church members

- Age groups (young people--middle age--old age ratio)

- Male--female ratio

- Percentage of new members

- Class I--class II--class III workers ratiol

- Percentage of regular visitors

- Climate of the church

It is easy to see that a larger church may also have a larger reservoir of persons who are able to speak publicly. A church with several highly educated members will probably also have more speakers. A church that belongs to the upper middle class'will probably do best reaching the same social group, and will accommodate the program to that class. A church with many recently baptized members may be more enthusiastic about a congregational evangelistic campaign. The variables will influence the campaign, and one seldom has any direct influence on such variables.

${ }^{1}$ class I workers are church members who are engaged in work for churched persons (for example, Sabbath school teachers, elders, ushers, young adult workers). Class II workers are church members who work for the unchurched (for example Bible study teachers, jail workers, soul winners). Class III workers are persons who are employed by the organization (for example, pastors, treasurers). 
2. Variables in regard to the pastor

- Pastor of a multi-church district or pastor of a single church district

- Main leadership style of the pastor

- Relation to evangelistic campaigns in general

A pastor of a multi-church district has to divide his time among several churches. He cannot work for one single church in the same way a pastor of a single church district can. The number of churches he cares for may affect congregational evangelistic campaigns. The pastor's leadership style has a direct influence, also. If he wants to do everything himself, if he wants to be the only one to speak publicly, it is hard to have a congregational evangelistic campaign. Besides this more autocratic style, there are other styles, such as the democratic and participative style or the laissez-faire style. If the pastor feels he is more an administrator or counselor than an evangelist, this will have a bearing on the congregational evangelistic campaign. The church does not have much influence on variables concerning the pastor.

3. Variables in regard to the prospective audience The church can decide which target group to select for its effort. It also can decide not to aim at a special target group, but to try to reach all people. 
Target groups can be classified as

- Age groups

- Socio-economic classes

- Educational classes

- Minorities

Target groups and their felt needs are at the same time variables in congregational evangelistic campaigns.

(4) Variables in regard to the campaign

This area of variables can be subdivided into: (a) variables in regard to the preparation of the campaign, (b) variables in regard to the implementation, and (c) variables in regard to the follow-up. With these variables one can exercise considerable influence.

a. Preparation

- Location of facilities for the campaign

- Number of meetings

- Reasons for chosen type of campaign

- Goals

- Finances

- Campaign as a part of a larger evangelistic concept

- Preparation of the church; for example, by 
training seminars, institution of an evangelism committee $^{1}$

- Preparation of the public; for example, advertising ${ }^{2}$

- Number of workers

b. Implementation

- Types of presentation

- Number of speakers and other workers

- Small groups

- Themes

c. Follow-up

- Kind of follow-up

- Number of workers

Obviously, there are many variables, some of which stand in certain relation to another--for example, target groups and themes. Some have more weight than others. Nevertheless, a model can be developed, but one must keep in mind that the variables may demand minor or, in some areas, major modifications. At the beginning the variables regarding the church and the pastor are the most important ones.

1 See Appendix 2. Questionnaire No.2, question 8a, points to some further variables.

2 See Appendix 2. Questionnarie No.2, question $8 d$, points to some further variables. 


\section{Roles of Congregation and Pastor}

This leads us to the question about which roles the congregation and pastor are playing in congregational evangelistic campaigns. If the campaign is an effort of the church, if church members and not the pastor are proclaiming the gospel publicly, what is the pastor's task? Is he out of work? $\mathrm{Cr}$ is he free to spend his time in other areas of his profession?

The New Testament already stresses the importance of church leadership, for the gift of leadership is one of the gifts mentioned. ${ }^{1}$ Elders are installed in the local churches. 2 It is not a question of whether or not leadership is necessary. The question is rather which leadership style is to be preferred in a given situation. The leadership of the pastor is essential, in congregational evangelistic campaigns, too. Lyle E. Schaller writes concerning pastoral leadership:

The larger the size of the congregation, the stronger the lay volunteers' expectation that the pastor will be an initiating leader... "Growing congregations are characterized by stronger pastoral leadership."... while the active leadership of the laity is the most important single factor in the numerical growth of most middle-sized congregations, the leadership of the pastor is the key in large congregations. In many situations, that alone may not be enough to reverse years of numerical decline, but few large churches will show a net increase year after year without the

\footnotetext{
${ }^{1}$ See Eph 4:11, 12; 1 Cor 12:28; Rom 12:8.

${ }^{2}$ See Titus $1: 5-9 ; 1$ Tim 5:17-19; 3:1-7 (bishop);
} Acts $20: 17,28-31$; 1 Pet 5:1-3; etc. 
benefit of the initiating leadership of a strong pastor. 1

Churches need leadership. They need the leadership of the laity plus the leadership of the pastor. Therefore, pastors have to be involved in the congregational evangelistic campaign. What form does this involvement take?

In congregational evangelistic campaigns, a committee has to be established to be responsible for the campaign, groups of speakers have to meet that are responsible for a single meeting, the church board has to think about recommendations made by the special committee (evangelism committee) and has to make decisions, laymen need help and have to be guided when they are preparing their talks, and so on. All this requires pastoral leadership. The pastor does not have less to do in comparison with a traditional campaign. He needs even

${ }^{1}$ Schaller, Growing Plans, pp. 84-86. Peter Wagner, pp. 61, 63, 65, writes: "In America, the primary catalytic factor for growth in a local church is the pastor... Vital sign Number one of a healthy, growing church is a pastor who is a possibility thinker and whose dynamic leadership has been used to catalyze the entire church into action for growth.... The pastor of a growing church is typically a strong authority figure and that authority has been earned through living relationships with the people." Whether this applies to West Germany in the same way it does to America is questionable, since the pastor in Germany may not have the same status as he has in America. Germans also seem to have a somewhat different view of democracy and leadership than Americans have which also affects churches and pastors. In any case, the pastor is very important in congregational evangelistic campaigns. 
more time, although he has no speeches to prepare and he may not often appear publicly. The tasks of the pastor can be described as training, initiating, organizing, supervising, and motivating.

1. Training. Before this type of campaign is selected by the church, the pastor may already have his vision. He may start with a training program to have able speakers and Bible study teachers ready for a future campaign and its follow-up.

2. Initiating. The pastor may take the initiative in suggesting several types of campaigns from which the church board or the entire congregation may select. 1 Taking the initiative in this case does not mean that the pastor tries to sell his suggestion. It means that he gives an impulse to motivate the idea of an evangelistic campaign, if it does not come from the church itself.

3. organizing. Usually the pastor is the chairman of the church board, and may also chair other committees. In any case, he has a certain influence when speaking up in a committee. Together with the lay church leaders he bears the responsibility for everything working well.

${ }^{1}$ sometimes even this suggestion comes from a group of church members. Different public efforts may be grouped together. In any case, flexibility on the part of the pastor is essential. 
4. Supervising. The pastor is the expert. He is the supervisor of all the groups that are designing a meeting. He is also the supervisor of the evangelism committee and all the other workers.

5. Motivating. The pastor tries to motivate and instruct the laymen. He encourages the workers. He gives advice, for example, on how to prepare a talk.

Although the campaign is the effort of the church, the success of it depends to a large degree on the involvement of the pastor behind the scenes. The pastor sets the tone. So, pastor and church must work together with this effort; the effort belongs to the church, but the pastor supports it.

\section{Preparation}

conducting a congregational evangelistic campaign requires much preparation. It takes more time in the preparation phase than does the traditional evangelistic campaign. However, it is very rewarding. Two factors contribute to the extensive preparation. First, it is necessary to train the church members. Second, it is team work, and team work always takes more time in the beginning, but it usually pays off very well. Later, more is achieved by having a group of workers instead of a 
single one. Spending sufficient time for the preparation is certainly a good investment. 1

one may distinguish between long-range preparation, middle-range preparation, and the short-range preparation. The long-range preparation is the preparation of the church and the training of a small group of laymen. The middle-range preparation happens in church board meetings or/and in church business meetings. The church may have a one-year plan or a five-year plan. The decision needs to be made--if possible--at least nine months in advance as to whether or not the church wants to have a congregational evangelistic campaign. The shortrange preparation refers to meetings by the groups of speakers, the composition of the talks, the gathering of all the other workers, the preparation of the public, and so on. The long-range preparation--that is the preparation of the church and the training of the laity--can almost be omitted, in the case that the church plans to start a second campaign soon after the first one is completed. Sometimes churches are so enthusiastic

${ }^{1}$ Consider Jesus Christ who trained his disciples for some three years. Coleman, p. 27 , says that we have to start training disciples like Jesus did. This will take time. It will be tiresome and painful and many people will not take notice of it. One has to decide what to choose: the applause of crowds, or the devotion of one's life to a few persons who will prosecute the work in the next generation. So, the question is wherefore and for which generation to live. The factor of time is mentioned again on pp. $33 f$. 
about the effort that they immediately start to plan a new one for the following year. Retraining may not be necessary again. A few sessions in which the stress is laid on improvement may be sufficient. However, if new church members or recently baptized persons who seem to be capable of talking publicly or of giving Bible studies are anxious to take part, then the training program should start all over again.1

\section{The Long-Range Preparation}

Long-range preparation is mainly the task of the pastor. He may dream about congregational evangelistic campaigns and start to prepare (1) the church and (2) a group of capable persons, just in case the church decides one day to have this kind of campaign. Out of this the preparation (3) of prospective guests comes forth.

\section{Preparing the church}

In West Germany some churches have not had evangelistic campaigns for many years. They often do not expect very much from public efforts. These churches must learn that even today evangelistic campaigns are necessary. Other churches are accustomed to public efforts though participation by church members is often very

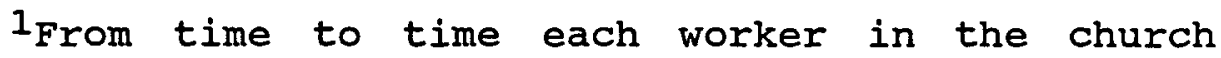
needs a course, a seminar, or a training session in order to be effective in his area, to be encouraged to go on, and to improve his skills. 
low. The pastor must create a climate that is prerequisite for a public campaign.

The pastor can contribute to this goal by his sermons. With his sermons he gives a signal to the church. A series of sermons that might be helpful, for example, would be a series on the church and its mission ${ }^{1}$ or on spiritual gifts. 2 This series should be preached in subsequent worship services--if possible--with only one interruption at the most. 3

II would suggest a series such as the following:

(1) 1 Pet 2:9-10 --Election and proclamation--privilege and responsibility of each church member

(2) Matt 25:14-30 --The parable of the talents

(3) Dan 1-4 -Daniel wins his king

(4) Eph 5:22-32 --Christ and his church--analysis of a church, goals, possibilities

(5) Luke 19:11-27 - The parable of the ten minas

(6) Luke 14:15-24 --The parable of the great banquet-inviatation and service

(7) Matt 13:31-32 --The parable of the mustard seed

2 Another example is this series recommended by $R$. Burrill, director of the North American Division Evangelism Institute of Seventh-day Adventists:

(1) The work of the pastor (Eph 4)

(2) The parable of the talents

(3) The priesthood of all believers

(4) The work of the laity

(5) Definitions of the different spiritual gifts

(6) How to discover one's spiritual gifts

(7) Baptism - ordination for service

3 Because almost all pastors in West Germany have multi-church districts, this is difficult. Nevertheless it is important to have a series with few interruptions. otherwise, little may be achieved and the first sermon is already forgotten when the second one is preached. The pastor should plan for series. If the series is rather long and he cannot neglect the other churches of his district for such a long time, a colleague or a layman could preach a sermon that will fit in the series. 
Besides the sermons, seminars can help to create the climate for a campaign in the church. There are seminars that focus on the church; for example, seminars on church growth, on spiritual gifts, on Adventist history, and so on. There are seminars that center on church members and guests; for example, health seminars, seminars on prophecy, and so on. 1 There are also church activities that can be used to invite guests and thereby help to create a missionary climate within the church. 2

Retreats are often very helpful. They may foster unity within the church and may help to develop "church growth eyes." 3

of particular importance are small groups within the church. It may be Bible study groups, prayer groups, or hobby groups. These cells often enliven the entire congregation, and they are needed for the follow-up.

${ }^{1}$ In the beginning these seminars may be used as single events without a larger framework so that the church gets used to small public events. Later on they may be set into a larger framework so that one can talk about sequence evangelism.

2 Holidays or celebrations like Mother's Day, Thanksgiving, Christmas, an anniversary of the church, a children's party, a retreat, a trip, special divine services, concerts, and so on.

${ }^{3}$ See Donald A. McGavran and Winfield C.Arn, Ten Steps for Church Growth (New York: Harper \& Row, 1977), p. 72 . 
Preparing a special

group of people

Even more important than the preparation of the entire church is the preparation of a special small group. Jesus Christ had such a small group when he lived on earth--the Twelve. They were trained for some three years. This training was both theoretical and practical in nature. 1 With Jesus' ascension the training was finished, and with Pentecost the real ministry of his disciples began. Today the same principle of electing disciples and of training them is appropriate. ${ }^{2}$

Steps to prepare

the special group

Seven steps are suggested to prepare the group of disciples for congregational evangelistic campaigns:

1. The pastor selects a group of individuals from his church with whom he wants to work and whom he wants to train. Prayer is an important factor in the selection process.

2. The group meets once a week for approximately two hours.

3. The time spent together is used for sharing, praying, lectures, and exercises with the group members.

${ }^{1}$ see the sending out of the Twelve in Matt 10.

2 see coleman's entire book which points to the same principle and encourages leaders to choose and train disciples. 
4. During the first or the second session a contract is worked out and ratified. 1 The contract helps everyone who is willing to agree to it to feel an obligation to participate actively in the group experience.

5. A topic for a series of sessions is chosen. Since the persons who get the training may be asked later on to give a public address, to conduct discussion groups, and to help with the follow-up in the form of Bible studies, seminars, or leading small groups, the following topics could be covered:

$1_{\text {An }}$ example is this contract for the Workshop Church and Mission:

(1) We will meet regularly every Tuesday night from 7.30 p.m. to approximately $9.30 \mathrm{p} . \mathrm{m}$. Nothing must hinder us from attending the session other than: illness, absence from home caused by our occupation, or scheduled vacations.

(2) We will meet until December 9, 1986. Then we will evaluate what we have done, and we will make a decision if and how we will continue the program.

(3) We want to be a lively group. When we are opening up to one another, we want to be confidential and keep information within our group.

(4) We plan to start the training sessions with the topic "Preparing Devotionals and sermons." After this is finished the following themes may be discussed: "Improving Sabbath School Teaching," "A Survey on World Mission," "Giving Bible Studies," "The Art to Lead to Decisions," "Working with Small Groups," "Church Growth Strategies Including Planting of New Churches." As far as possible we will participate in the seminars "Creative Listening" and "The Advent Movement--the Expectation of Christ's Second Coming."

(5) The program is to consist of a theoretical and a practical part in which we will want to participate. The goal of the entire program is to build up the church and to give impulses to our mission to the world. 
(a) Preaching sermons

(b) Teaching Sabbath School lessons

(c) Giving Bible studies

(d) Helping people to make decisions

(e) Working with small groups

(f) Principles of church growth

(g) The history of the Adventist church

(h) World mission

(i) Skills of listening and caring.

The order of the topics depends to a certain degree on the group. The proposed order, however, seems to be particularly helpful. The topics which are the most urgent ones in regard to the campaign are (a) to (d). While the group meets weekly, a weekend seminar on world mission, on the history of the Adventist church, on skills of listening and caring, and on church growth principles could be profitable. If "working with small groups" cannot be covered, by attending their group regularly the group members will have had some kind of experience at least.

6. Exercises should be prepared and practical work provided. If the training consists of lectures only, it might be better not even to start. The practical part is the most important part. Group members need to teach Sabbath School lessons and preach sermons. They 
need to accompany the pastor when he gives Bible studies, start giving Bible studies themselves, and so on.

7. After about eight to ten sessions there should be a time for evaluation. A questionnaire may be handed out that asks for the benefits of the sessions, for the areas that need improvement, for the continuation of the program, for the theme that should be dealt with, and so on. A break of several weeks should ensue before the next series of sessions is started.

Programs to prepare

the special group

The programs listed below may be used to train the special group. In the beginning, one may select the more important ones, and later on the others may be covered.

\section{Preaching sermons. 1}

First session

- Sharing

- Time of prayer

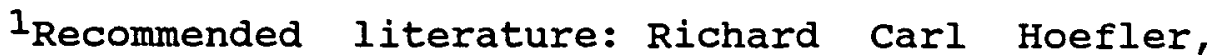
Creative Preaching and oral writing (Lima: The C.S.S. Publishing Company, 1978); Richard Nötzelmann, Arbeitsunterlagen zum Verhaltens-Training Rhetorik - wirkungsvoll sprechen, vortragen (München: Institut für Berufsbildung, 1979); Haddon W. Robinson, Biblical Preaching: The Development and Delivery of Expository Messages (Grand Rapids: Baker Book House, 1983). 
- Information on goals, planned sessions and contract

- Handing out a questionnaire ${ }^{1}$

- Lecture: "Preaching: God's Commission--An Introduction"

- Exercise: Off-the-cuff speech for two minutes

- Announcements and prayer.

Second session

- sharing

- Time of prayer

- signing the contract, analysis of the questionnaire handed out at the first session

- Lecture: "Topical Preaching"

- Exercise: Preparing this kind of sermon together

$1_{\text {The }}$ questionnaire may contain the following questions with a choice of provided answers which may be marked, and with some empty lines for further comments: (1) What does the church--in your opinion--expect from a sermon or devotional? (2) What do I personally expect from a sermon or devotional? (3) What does a good devotional or sermon contain in my opinion? (4) What do I have to criticize in the average sermon? (5) What can I myself do so the sermon I am hearing becomes more beneficial to me? (6) How can I help the preacher during the presentation of his sermon? (7) Have I already preached a sermon or have I given a devotional? (8) Am I willing to preach a sermon or to give a devotional? (9) How would I prepare a sermon or a devotional? (10) Which resources and instruments would I use for the preparation? (11) Am I willing to copy the sermons of other persons? (12) What would I mainly prefer to talk about? (13) What is the reason for my preaching a sermon or having a devotional? (14) At what time will I be ready to do this? 
- Homework: Preparing a topical sermon ${ }^{1}$

- Prayer.

Third session

- Sharing

- Time of prayer

- Presentation of some of the topical sermons that were prepared by the participants and evaluation ${ }^{2}$

- Lecture: "Expository ${ }^{3}$ Preaching--Part 1"

- Exercise: Drawing a text from among slips previously prepared which has to be set in its context

- Homework: Preparing an expository sermon 4

- Prayer.

Fourth session

- Sharing

- Time of prayer

- Presentation of the rest of the topical sermons and evaluation

$1_{\text {Each }}$ participant draws a sheet of paper with a certain topic. The sermon to be prepared should take about 5 to 10 minutes--a devotional rather than a sermon.

2 An evaluation sheet is used for this. topic.

${ }^{3}$ That is, preaching on a Bible text and not on a

${ }^{4}$ Each participant will draw a Bible text for his sermon from among slips previously prepared. The sermon should last about 5 to 10 minutes. 
- Lecture: "Expository Preaching--Part 2"

- Announcements and prayer.

Fifth session

- Sharing

- Time of prayer

- Exercise: Recognizing the structure of Biblical passages

- Lecture: "Expository Preaching--Part 3"

- A short expository sermon preached by the pastor

- Announcements and prayer.

Sixth session

- Sharing

- Time of prayer

- Exercise: Preparing an expository sermon together

- Handing out a bibliography

- Announcements and prayer.

Seventh session

- Time of prayer

- Presentation of the expository sermons by the participants and evaluation

- Lecture: "Rhetoric--Part 1"

- Announcements and prayer.

Eighth session

- Time of prayer 
- Lecture: "Rhetoric--Part 2"

- Exercises: Cutting down long sentences, sketch to practice the variability of the human voice, reading a story, and reciting poems

- Questionnaire on the effectiveness of the coursel and discussion on the questionnaire

- Decision if and when to continue and which topic to choose

- Prayer.

The length of the course depends to a large degree on the number of participants, for each one has to present two short sermons. Thus, the number of sessions and the contents are variable. The above-mentioned outline of the program is only a suggestion. After the group meetings the participants should be encouraged to preach in the church. In west Germany the order of worship is short in the SDA churches. 2 Therefore the sermon can be 30 to 45 minutes long. The multi-church

$1_{\text {The }}$ questions for this questionnaire might include: (1) In what way did this seminar on preaching sermons help me personally? (2) In which areas are improvements desirable? (3) Does it make sense at all to conduct courses like this one? Why? (4) What do I think about continuing our small group experience with a new topic? (5) Which one of the following topics would I like to have first? (6) Am I willing to participate in this group even if the topic $I$ chose is not dealt with immediately? (7) Am I willing to use my new knowledge in serving the church and the environment?

2 It consists of announcements and offering, hymn, prayer, sometimes special music, sermon, hymn, prayer or benediction, hymn. 
districts demand quite a number of laymen to preach sermons. The participants of the seminar on preaching are asked to form teams of three and then to preach their small sermons publicly. Thus, instead of one sermon of about 35 minutes, the sermon would be divided into three segments of about 10 minutes each. The speeches should fit with one another. Between the first and the second segments and between the second and the third, some special music may be used or a hymn may be sung. ${ }^{1}$ After the experience of preaching a short sermon publicly, the group members are asked to prepare sermons for the next quarter of the year. This time the sermons should be somewhat longer. Instead of three persons proclaiming the message, as done before, only two should preach at a time. The next step for each layman is to preach a full-fledged sermon. After this is done they are able to participate in a congregational evangelistic campaign as public speakers. ${ }^{2}$ The seminar on preaching also has side-effects on the participants: studying God's word becomes more meaningful and exciting for them, and they

\footnotetext{
this approach.

${ }^{2}$ Some will participate in the campaign with less experience, too. But it is preferable to have had some experience in speaking publicly, because some mistakes may be prevented in this way.
}

${ }^{1}$ Usually the church is very enthusiastic about 
are able to prepare their own Bible studies which may be given to interested persons. 1

Teaching Sabbath School lessons. 2 The sessions for teaching Sabbath school lessons are similar to the sessions of the course "Preaching sermons." They contain the same elements. Therefore only the themes of the lectures, the exercises, and the homework are mentioned here.

First session

- Introduction: analysis of the current situation in our Sabbath school

- Lecture: "The Art of Asking Good Questions"

- Exercises: Recognizing different types of questions, changing bad questions into good ones

- Homework: Preparing good questions for the next Sabbath School lesson.

Second session

- Introduction: "Jesus in Conversation"

$1_{\text {This becomes essential with the follow-up. }}$

2 Recommended 1iterature: Die induktive Gesprächsführung - studienheft für Kursteilnehmer (Ostfildern: Gemeinschaft der siebenten-Tags-Adventisten, süddeutscher Verband, n. d.); Lehrgang für induktive Gesprächsführung - Anleitung zur Durchführung eines Grundkurses (Ostfildern: Gemeinschaft der Siebenten-Tags-Adventisten, süddeutscher Verband, n. d.); Lehrgang für induktive Gesprächsführung - Anleitung zur Durchführung eines Aufbaukurses (Ostfildern: Gemeinschaft der SiebentenTags-Adventisten, süddeutscher Verband, n. d.). 
- Review of the homework

- Lecture: "The Importance of the starting Question in Discussion Groups"

- Exercise: Finding starting questions on given topics

- Lecture: "The Sabbath School Teachers' Meeting"

- Homework: Preparing at least three different starting questions for the next Sabbath School lesson along with good follow-up questions.

Third session

- Introduction: "Forms and contents"

- Review of the homework

- Lecture: "The Disposition of the Lesson"

- Exercise: Working together at the disposition and the questions of a given lesson

- Homework: Preparing short lessons of about ten minutes time to be taught the next time. 1

Fourth session

- Participants teach their lessons and receive evaluation

- Lecture: "Teaching Expository Lessons."

In this course the members of the group are taught to avoid certain types of questions: Questions

${ }^{1}$ As lessons Bible study guides may be used so the link to evangelism will be provided. 
which consist of mutilated sentences or words; ${ }^{1}$ questions which allow only of yes or no answers; questions which allow only of a single word/phrase answer; double questions; and didactic questions. Instead the participants learn to use genuine questions which open up conversation. Besides the focus on questions, the small group is taught to use an inductive approach--that is, moving from the general to the specific, from the fringe problem to the central problem. Both skills are essential, first, for the small discussion groups within the congregational evangelistic campaign, and second, for the follow-up and the preparation of the campaign by Bible studies and small groups. All the time these skills can be used and can be improved as the group members are asked to teach Sabbath School classes in the church.

Giving Bible studies and preparing for decisions. ${ }^{2}$ Here again, as is in the discussion on giving --what?"

1For example: "'In the beginning God created...'

${ }^{2}$ Recommended literature: Die Gemeinde, eine Schule für Missionsarbeit - Missionshelferkursus für die Mitteleuropäische Division, Abteilung Heimatmission (Darmstadt: Gemeinschaft der Siebenten-Tags-Adventisten, Mitteleuropäische Division, Abteilung Heimatmission, $n$. d.): Evangelisation des Predigers im Bezirk - Fortbildungslehrgang Abtenau 1971 und 1972 (stuttgart: Gemeinschaft der Siebenten-Tags-Adventisten, Süddeutscher Verband, 1973); Finley, Entscheidungen - Menschen für Christus gewinnen; Wenn man dich fragt nach deinem Glauben. See also Engel, pp. 63-87, 205-220. 
Bible studies, only the lectures, the exercises, and the homework are mentioned.

First session

- Lecture: "Presuppositions concerning the Bible Study Teacher"

- Exercise: Finding Bible texts for Biblical topics ${ }^{1}$

- Lecture: "The Preparation of Bible Studies"

- Exercise: Groups of two, one partner in the role of the teacher, the other in the role of the interested person, talking about the topic which was drawn

- Homework: Preparation of a Bible study; arrangements for the participants to accompany the pastor once a week and observing him giving Bible studies. (This point is carried through at least to the end of the course, but gradually the lay person should be involved in giving Bible studies himself, too. ${ }^{2}$ ) prepared.

${ }^{1}$ This topic is drawn from among slips previously

2 In the beginning the lay person observes and the pastor gives the Bible study. Then the laymen starts to help the pastor. He may, for example, take over a prayer. After this both do it together. Later on the group member gives the Bible study and the pastor helps. A step further the pastor is oniy observing the process. Then the pastor leaves the layman alone. Duplication has taken place. If the laymen then starts to train others, multiplication will occur. See Kuhne, pp. 21-28. 
Second session

- Exercise: Participants give the prepared personal Bible studies followed by evaluation

- Lecture: "The Personal Testimony"

- Homework: Working out a personal testimony.

Third session

- Exercise: Participants give their testimonies and evaluation

- Lecture: "Finding Bible study Partners"

- Exercise: Making a plan about how to get Bible study contacts

- Prayer

- Homework: Trying to start with one's plan.

Fourth session

- Lecture: "Conducting Bible studies"

- Exercise: Participants continue to give their prepared Bible studies and evaluation

- Lectures: "Bible Studies Order" and "Resources and Instruments for Bible studies"

- Homework: Preparing another Bible study using Bible study guides, slides, or flannelboard illustrations.

Fifth session

- Exercise: Participants give the Bible studies using aids

- Lecture: "Leading Men to Christ" 
- Exercise: Observing the pastor seeking to lead a partner to Christ

- Homework: Preparation to be able to lead a person to Christ.

Sixth session

- Exercise: Continuation of giving Bible studies

- Lecture: "Stabilizing New Members"

- Exercise: Leading a person to Christ

- Homework: Visit a newly baptized church member. Seventh session

- Lecture: "Leading People to Make DecisionsPart 1"

- Exercises: Find biblical promises, try to help a partner make a decision for the biblical Sabbath, for the health doctrine, for tithing, for baptism.

Eighth session

- Lecture: "Leading People to Make DecisionsPart 2"

- Exercise: Try to work with excuses and deal with controversy.

This course is important for the campaign itself. The speakers may then be called upon to give their testimony. They may have to make a call. In the small group sessions which belong to the campaign, topics may arise that are Bible study themes. The follow-up requires 
a staff of well-trained Bible study teachers. In the time before the campaign starts, as many Bible studies as possible should be given to assure a good number of prospective visitors.

Working with small groups. 1 The participants have already been meeting as a small group for the other sessions. In their small group they will have received some practical insights as to how a small group functions. This course provides some theoretical knowledge as well as some new practical experiences. 2 The basic elements--namely sharing, praying, covenant making--are the same as with the previous course. So, they are not mentioned again.

First session

- Lecture: "The Need for Small Groups"

$1_{\text {Recommended literature: Hans Nater, Mut zum }}$ Hauskreis (Gladbeck: Schriftenmissions-Verlag, 1983); Lyle E. Schaller, Assimilating New Members (Nashville: Abingdon Press, 1978).

2 See also David o. Moberg, The Great Reversal: Evangelism and Social concern, rev. ed. (Philadelphia: J. B. Lippincott Company, 1977), p. 80; Johnny Durant Johnson, "The Development, and Evaluation of a Program for Bible Evangelism to Be Used by Layman Employing SmallGroup Methods as a Basic Format" (D.Min. project, Andrews University, 1977); pp. 7-30; Paul M. Miller, Group Dynamics in Evangelism (Scottdale: Herald Press, 1961), pp. 175-188; Paul Yonggi Cho, Successful Home Cell Groups, Plainfield: Logos International, 1981), pp.107118; Curtis R. Sylvester, "A Model for Lay Ministry Based on the small Group Concept in a Congregation-Wide setting" (D.Min. project, Drew University, 1983); Kennedy, pp. 153-161; Miguel A. Cerna, "Small Groups that Care Makes a Church that Grows," Administry, summer 1983, p. 10. 
- Exercise: Discussing the different types of small groups, their advantages and goals

- Homework: Preparation for taking over the time of sharing in this small group during the next sessions.

Second session

- Exercise: Time of sharing conducted by group members

- Lecture: "The Elements of Small Group Life"

- Exercise: Discussing the role of the pastor in small groups

- Homework: Trying to start a small group or at least to participate in another one.

Third session

- Exercise: Time of sharing conducted by group members

- Lecture: "Resources for Small Groups"

- Exercises: Discussing the crises of small groups and their remedies; discussing the question of how to attract group members.

This course contributes in another way to the preparation of the campaign. Not only are church members trained, but the small groups which may emerge are beneficial for the campaign. 1

1Prayer groups are needed for the campaign. Bible study groups, sports, hobby, and sharing groups provide a reservoir of people that may attend the evangelistic 
Principles of church growth. Another session series on church growth might be helpful for small groups. The session format suggested is as follows:

First session

- Exercise: Looking for biblical support of the thesis that God wants his church grow

- Lecture: "Signs of a Healthy Church--Part 1"

- Homework: Comparing the growth of the church during the last ten years and the growth of the community.

Second session

- Lecture: "Signs of a Healthy Church--Part 2"

- Exercise: Writing down changes the church must submit to if it wants to grow, and discussing the price of growth for the local congregation

- Homework: Finding and comparing the number of church members who are active within the church with the number of those whose ministry is directed to the people outside the church.

Third session

- Lecture: "Spiritual Gifts--Part 1"

- Exercise: Spiritual gifts inventory

- Homework: Making a list of persons that are

campaign. Task-oriented groups are also essential for the campaign. 
within the reach of the church and trying to minister to them with one's gift.

Fourth session

- Lecture: "Spiritual Gifts--Part 2"

- Exercise: Group discussion about the spiritual gifts of each group member

- Homework: Testing to ascertain if one has the gift of evangelism.

Fifth session

- Lecture: "The Planning Process--Analysis of the Church and Demographics"

- Homework: Talking with at least two church members about their feelings in regard to the church and about the visions they have for the church.

Sixth session

- Review of the homework

- Lecture: "The Planning Process--Goal Setting, Program Developing, Implementation, 'Super vision, Evaluation"1

- Homework: Preparing a one-year plan for the church.

1 See Hunter, "Equipping Church Laity for Evangelistic Ministry," pp. 109-113; Alvin J. Lindgren and Norman Shawchuck, Let My People Go--Empowering Laity for Ministry (Nashville: Abingdon Press, 1984), pp. 73-112. 
Seventh session

- Review of the homework

- Lecture: "Approaches--Felt-Needs and Sequence Evangelism"

- Exercise: Discussing the question of receptivity

- Homework: Survey in the neighborhood to detect felt needs.

Eighth session

- Lecture: "Church Planting--Part 1"

- Exercise: Putting down reasons for the tendencies of churches not to split up into two congregations, and developing strategies to overcome those tendencies.

Ninth session

- Lecture: "Church Planting--Part 2"

- Exercise: Examining whether there is any chance for one's church to plant a new congregation, and starting to make a plan if the result is positive.

The goal of the course ${ }^{1}$ is to create church

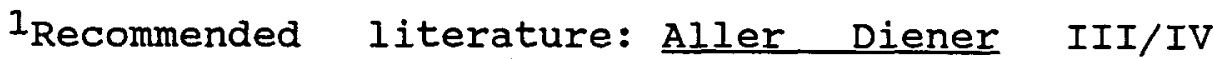
1981. Stoffsammlungen und Mitteilungen der EAD-Predigtamtsabteilung (Bern: Gemeinschaft der Siebenten-TagsAdventisten, Euro-Afrika-Division, 1981); Mark Finley, The Way to Adventist Church Growth (Arroyo Grande: Concerned Communications, n.d.); Alvin J. Lindgren and Norman Shawchuck. Management for Your Church (Nashville: Abington, 1981); Donald A. McGavran and Winfield C. Arn, Ten Steps for Church Growth (New York: Harper and Row, 
growth eyes, and to motivate church members for the campaign.

History of the Adventist church. Another suggested small-group seminar is Adventist history. The sessions would be as follows:

First session

- Exercise: Questionnaire on the identity of the SDA church

- Lecture: "Roots of the Advent Movement"

- Exercises: Finding texts on Christ's second coming with each writer of the New Testament; responding to the reproach that SDAs once set a date for Christ's second coming.

Publishers, 1977); Lyle E. Schaller, Growing Plans; The Caring Church - A Strategy for North America, prepared by the North American Division of the General Conference of Seventh-day Adventists in cooperation with the Center of Continuing Education of Ministry (Washington, D. C.: Review and Herald Publishing Association, 1983); C. Peter Wagner, Your Church Can Grow: Seven Vital Signs of a Healthy Church (Ventura: Regal Books, 1984). See also Rodger I. Dudley and Des Cummings, "A study of Factors Relating to Church Growth in the North American Division of Seventh-day Adventists," Review of Religious Research 24 (1983): 322-333; George E. Knowles, How to Help Your Church Grow (Washington, D. C.: Review and Herald Publishing Association, 1981), pp. 26-35; Stan Hudson and Donald McGavran, "McGavran on Adventist Church Growth," Ministry, May 1985, pp. 16-19; Borge Schantz; "Church Growth: Catalyst or Method?" Ministry, December 1985, pp. 7-9; Lyle E. Schaller, Hey, That's our Church (Nashville: Abingdon Press, 1978), pp.34-38; Jimmy R. Allen, "A Society of Innkeepers," Southwestern Journal of Theology 17 (1975): 9-19; Engel, pp. 83, 93-101, 291-295, 314-325; W. C. Scales, "Seven steps to Church Growth," Administry, Autumn 1982, pp. 4, 14; Administry, Winter 1984 . 
Second session

- Exercise: Responding to the reproach that SDAs are an American sect

- Lecture: "The Advent Movement in Europe."

Third session

- Review of the hope of the advent in the Bible, of false expectations of christ's return, and of the Advent movement in Europe

- Lecture: "The Miller Movement"

- Illustration

- Questions.

Fourth session

- Review of the growth and the decline of the Miller Movement

- Lecture: "Formation and Doctrines of the SDA Church"

- slides about Battle Creek

- Questions.

Fifth session

- Exercise: Discussion about different organizational models

- Lecture: "The SDA Church since 1863"

- Multi-media show as a summary of the seminar. This course ${ }^{1}$ helps persons to know who SDAs are

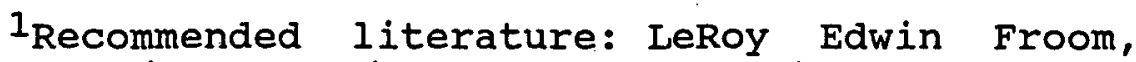
Movement of Destiny (Washington, D.C.: Review and Herald Publishing Association, 1971); J. N. Loughborough, Rise 
and what their task is in the world. This is a presupposition for all evangelistic activities.

World mission. 1 The world mission sessions are designed to broaden the horizon of the participants. The understanding of evangelism overseas can help to fructify evangelism at home, for similar principles are at work in both cases.

First session

- Exercise: Finding biblical examples for world mission

- Lecture: "The History of World Mission"

- Homework: Putting down ideas as to how to reach foreigners in West Germany.

second session

- Exercise: Talking about the homework and--if possible--making plans

- Lecture: "The Challenge of World Mission"

and Progress of the Seventh-day Adventists (Battle Creek: General Conference Association of Seventh-day Adventists, 1892); C. Mervyn Maxwell, Tell It to the World--The Story of Seventh-day Adventists, 2nd ed. (Mountain View: Pacific Press Publishing Association, 1982); Konrad F. Mueller, Die Frühgeschichte der Siebenten-Tags-Adventisten bis zur Gemeindegründung 1863 und ihre Bedeutung für die moderne Irenik (Marburg: $N$. G. Elwert Verlag, 1969).

$1_{\text {Recommended literature: Ralph D. Winter and }}$ Steven C. Hawthorne, eds., Perspectives on the World Christian Movement--A Reader (Pasadena: William Carey Library, 1983). 
- Homework: Try to meet a foreigner and communicate with him/her and write down the problem.

Third session

- Lecture: "Cross-Cultural Communication"

- Exercise: Discuss the question as to how the church is dealing with foreigners, how church members would react to establishing cultural churches, and how churches based on different cultures and languages could cooperate with each other.

Skills of listening and caring. ${ }^{1}$ Listening and caring are important skills in any caring church situation. Sessions would be as follows:

First session

- Exercises: To get to know each other more intimately: talking about the place of one's birth and about circumstances related to one's birth, talking about one's first names, choosing partners and forming groups of six persons

$1_{\text {Recommended literature: Gerard Egan, Der fähige }}$ Helfer - Grundformen helfender Beziehung (Gelnhausen: Burckhardthaus-Laetare Verlag, 1979); Kenneth J. Mitchell and John S. Savage, Skills for Calling and Caring Ministries. "Learning the Language of Healing." (Pittsford: L. E. A. D. Consultants, 1982); John S. Savage, The Apathetic and Bored Church Member: Psychological and Theological Implications (Pittsford: L. E. A. D. Consultants, 1976). 
- Exercises: One person tries to enter a conversation that is going on, the others try to prevent him from participating in the conversation, filling out the work-sheet "Knowing you Belong" and discussion

- Lecture: "The Church Member on the Dropout Track"

- Study of "paraphrasing"

- Exercises: Work-sheet on paraphrasing, practicing paraphrasing

- study of "perception check"

- Exercises: work-sheet on perception check, work-sheet on paraphrasing and perception check, practicing perception check.

second session

- Exercise: Practicing perception check and paraphrasing

- Lecture: "Problems with Communication"

- Exercise: "Quarreling"1

- Study of "behavior description"

- Exercise: Work-sheet on behavior description

- study of "creative questions"

${ }^{1}$ Two persons talk about a subject and hold quite the opposite positions. However, before one is allowed to bring forward an argument, one has to repeat the other's statement. 
- Exercises: Work-sheet on creative questions, practicing all the communication skills that were taught up to this point.

Third session

- Review of the skills the participants have already practiced

- Lecture: "Model of a Helping Conversation"

- study of "direct expression of feelings"

- Exercises: Two work-sheets on direct expression of feelings

- Lecture: "Reaction to Criticism"

- study of "fogging"

- Exercises: Practicing how to deal with fogging and the other skills

The skills of listening and caring create an atmosphere that makes one feel accepted and cared for. This is true for visits with guests, for Bible study contacts, for small group experiences--whether before the campaign or during the campaign--and even for the church at worship. This warm atmosphere is very much appreciated today and is, therefore, an important tool for winning people to Christ.

Summary

This rather lengthy section depicts what is practically the heart of the campaign. The preparation of the special group must not be underestimated, because the 
implementation of the campaign and the follow-up are dependent on it. When the church members are well prepared and trained and have already had some experiences, then--with God's help--the campaign can become quite successful. The laymen can be expected to be very enthusiastic, also, because they realize that they are in fact capable of conducting evangelistic campaigns.

This long-range preparation takes time. One has to estimate as much as an entire year. Jesus himself took time to train his disciples--even more time. When the first campaign is over and the next one is started, there is no need to repeat a long-range training phase again-at least not with the group already trained. The pastor may select a new group to be trained, and he may provide some leadership training so that more trainers are at hand. In this way quite a number of church members can be involved in active service that for a long time has been reserved only for the pastor. As a result, many more people can be won for Christ.

\section{The preparation of}

prospective guests

The preparation of the church and this special group of church members leads also to the preparation of prospective guests. There are Bible studies going on, there are small groups organized, church members build a web of friendships, and these friends are invited 
to attend the meetings of the campaign. Because of friendship ties they are good candidates for coming to the meetings and for making decisions, too. The open atmosphere and the small discussion groups help them to be at ease and to enjoy the conversation and the fellowship. Besides Bible studies and small groups, other entry events like seminars on health, family life, and so on may be planned. An interest file should be kept and persons previously contacted should be invited regularly to special meetings of the church.

The Middle-Range Preparation

The middle-range preparation is mainly the task of a committee, but partly the task of the pastor. In any case, the pastor functions as a supervisor. Four main steps belong to the middle-range preparation:

1. The decision to have a congregational evangelistic campaign

2. The institution of an evangelism committee

3. The work of the evangelism committee

4. The involvement of the church.

The decision to have a congregational evangelistic campaian

First, the decision has to be made that the church will have a congregational evangelistic campaign. In the small training group, the pastor may already have talked about this type of campaign along with others. 
He may have encouraged the group members to try a congregational evangelistic campaign. Although church members may promote this type of campaigri, the pastor probably has to take the initiative.

When the church board meets to plan an evangelistic campaign, the pastor may introduce different types of campaigns. ${ }^{1}$ The board members get a broader view of the diversity of evangelistic campaigns. The pastor should also mention the congregational type and talk about the advantages this type has--namely, the chances of reaching the secular public and reviving the church. When the board agrees to have this type of campaign, the church should meet at a church business meeting. It is very important that the church board be really enthusiastic about it. It is counterproductive to try this when the church board feels compelled to comply or when there was only a bare majority vote.

In the church business meeting the head elder or the pastor presents the suggestion of the church board to conduct a congregational evangelistic campaign. This may

$1_{\text {There are differences regarding the time frame }}$ of the campaign, regarding the speaker, regarding the topic, and the kind of presentation. Differences in regard to the time frame: long-range campaigns and short-range campaigns; differences in regard to the speaker: evangelist, pastor, a layman, a team, groups of laymen; differences in regard to the topic: health evangelism, archeology, biblical doctrines, and so on; differences in regard to the kind of presentation: seminar style or lecture/sermon style. 
be done in a way similar to the way the pastor talked about the campaigns in the church board meeting. 1 The church has probably already had some exposure to the preaching of the members of the training group in the meantime. Usually the church can be expected to consent to the suggestion of the church board. Information should be given about the role of the church in this campaign and the expectations concerning cooperation in diverse areas. There should be time for the church members to ask specific questions. If the church does not really want to try this approach, it should not be carried out. But if it consents, one can move ahead to the next step.

The establishing of an evangelism committee

A special evangelism committee which is responsible only for this campaign must be established. It should have about twelve members. 2 The chairman may be the lay activities leader, the head elder, or the pastor. Members of this committee need to include the pastor, the head elder, the lay activities leader, the leader of the

1For example, this outline can be used: (1) Why do we want to have evangelistic campaigns? (2) What can be said pro and con about evangelistic campaigns? (3) What types of campaigns exist? (4) What about congregational evangelistic campaigns?

2 Most churches in West Germany do not have a lay activities council, or if they have one, it usually does not work. If there is a functioning lay activities council, it may be inserted into the evangelism committee, if it is not too large. 
youth department, and persons who are willing to take over the leadership of small groups yet to be formed which will be responsible for carrying out the program of at least one evangelistic meeting. 1 This committee is responsible to the church board. It makes suggestions, but decisions are taken by the church board; so the church board has to be informed constantly about the work of the evangelism committee. Probably some of the evangelism committee members will be members of the church board, too, though it is best that their number should not be too large. The committee has to meet regularly--at least once a month to begin with, often more as plans progress.

The work of the evangelism committee

First, the objectives of the campaign must be clarified. After this is done, work can start on all other points. These include decisions about:

1. The number of meetings within the campaign, the number of meetings per week, the days of the week on which meetings will be held.

IThese persons may be members of the group which was/is trained by the pastor. 
2. The place where the meetings will be held--church building or public hall. 1

3. The time when the campaign is to take place.

4. The target group which will be addressed--an age group, a socio-economic class, an educational class, a minority, or all of them.

5. The kind of continuing preparation the church will undergo--church business meetings, seminars, retreats, a week of spiritual emphasis, or other means.

6. The organization of all the helpers that are necessary for the campaign: in which areas are helpers needed? How many? Who will be the respective leaders? How will they be solicited?

7. The selection of the speakers. 2

8. Financial arrangements--support by the local conference, by the loal church, by collecting offerings? A budget has to be made up. 3

Isee Arthur Nelson Patrick, "A Study of Methods to secure and Maintain an Audience in SDA Evangelism" (M. Div. thesis, Andrews University, 1972), p. 45; Mark Finley, studien zur offenbarung - Handbuch für Evangelisation (Bern: Gemeinschaft der Siebenten-Tags-Adventisten, Euro-Afrika-Division, Predigtamtsabteilung, 1984), pp. 21-22.

${ }^{2} \mathrm{~A}$ reservoir for the selection of these speakers is the group which got and still get training. However, non-group members may be chosen, too. pp. 23-25.

${ }^{3}$ See Mark Finley, studien zur offenbarung, 
9. The selection of the main theme.

10. The formulation of the themes for the different meetings.

11. The preparation of the public: Advertisements-bills, handbills, invitation letters. Who is responsible for the design of bills and handbills? What dead-Iine must be set? How many are to be printed? How are they to be distributed?

12. The elements of the meetings: The time for public prayer, the means of the presentation, the small discussion groups. Questions concerning the discussion groups: Where to meet after the presentation? Formal or informal style? What to talk about?

13. The preparation of the campaign by public events and the follow-up: whether or not a part of an overall concept, for example, shall there be a five-year plan? How should it work? What must be planned?

The evangelism committee has a lot to do. Many suggestions and decisions have to be made, and there is room to be creative. Though this work may be difficult, it is very rewarding for church members to work together in this way. The church is tied together.

\section{The involvement of the church}

The church has to be informed about the decisions at church business meetings. Additional suggestions may 
come from members. All church members should receive a questionnaire on which they can mark areas where they are willing to participate. 1 Many helpers are needed. Members should also get a blank on which to put down the names and addresses of people who might be interested in attending the meetings. 2 The addresses that come in are added to the interest file. The questionnaires are analyzed. Names of church members who are willing to help with the campaign should then be arranged according to the main areas of work; a leader for each area is selected. 3 The leaders of the teams to prepare and implement the presentations of the meetings start to select group members with whom to work. Some may have put their names down to participate in the public presentations, but often there are capable persons who do not mark the appropriate box. They have to be asked personally, and are often willing to participate in this area if thus asked. The evangelism committee and the church board need to be informed about all persons who are willing to speak publicly and about the respective teams. In this way, church members are activated.

$1_{\text {See Appendix } 4 .}$

${ }^{2}$ See Appendix 4.

${ }^{3}$ For example, a leader for the ushers and hosts/ hostesses, a leader for the transportation service, and so on. 
The middle-range preparation needs to starts about six to nine months prior to the campaign.

The Short-Range Preparation

The short-range preparation is mainly the task of the preaching teams and the groups of helpers. Supervision is performed by the evangelism committee and the pastor. The short-range preparation should start at least three months prior to the campaign. It should consist of these points:

1. Prepare the presentations for the meetings

2. Provide needed materials

3. Instruct the groups of helpers

4. Take care of the advertising

5. Motivate the church.

\section{Preparing the presentations}

The teams which are responsible for one or more meetings each need to meet regularly as a small group. They will pray and think about the outline of the presentation of a meeting, discuss the content of the presentation, and consider carefully which means to choose to give a powerful message to the audience. ${ }^{1}$ when the outline of the presentation is finished, the team

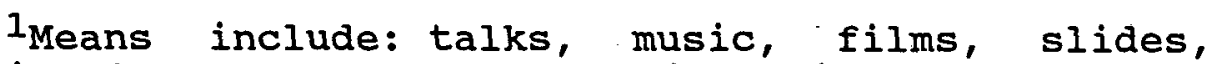
multimedia shows, dramas, panel discussions, dialogues, readings, prayers, and so on. 
members decide who will get what assignment. 1 They rehearse songs and readings. They discuss the speeches which were prepared by team members and talk about the materials and the equipment they need. They also may prepare questions for the small discussion groups in the campaign.

The outlines and speeches of the teams are given to the pastor who looks them over and gives further suggestions if necessary. All the time the pastor may be asked for advice. It may also be helpful if the pastor participates in a team session with each group. The evangelism committee is informed as to how the work is proceeding within the teams. This committee also sets a deadline when all presentations should be ready. The teams are asked to rehearse their entire program. This is observed by the pastor, the head elder, and the lay activities leader. Suggestions for improvement may be made.

All the teams meet together once or twice. This may be at the beginning of their work to allow for instructions and the asking of questions. It may also be after the presentations are ready and shortly before the campaign, so some final questions can be answered and to

lone may be asked to have a talk, another to say words of welcome, another to have a prayer and a testimony, the next one to provide some special music, or to lead a panel discussion. 
make sure that all the organization is running well, and to pray.

\section{providing the materials}

Several persons may be responsible to provide all the materials, but one church member should be in charge to coordinate all the requests for material. He gets the information about what is needed from the teams, the evangelism committee, and the group of helpers. He has a check list and makes sure that everything that is needed is at hand. His helpers may take care of different fields of material, which they need to provide. 1

\section{Instructing the groups of helpers}

The group of helpers, such as ushers, hostesses, and transportation personnel are to meet once with their leaders, the pastor, and some representatives of the evangelism committee to get instructions about their tasks.

\section{Taking care of the advertising}

The lay activities leader is responsible for the area of advertising. He takes care that ads get to the

IFor example, one is providing all the technical equipment such as film projectors and overhead projectors, music boxes, microphones, and extension cords. Another one takes care of all the material which must be ordered such as Bibles, books, pamphlets, films, and slides. Another one buys herbal teas, soft drinks, and cookies. And still another is responsible for providing photocopies. 
newspapers. Bills and handbills must be printed and picked up at the printer. The bills must be posted and handbills have to be distributed by the church members. 1 Handbills with a covering letter should be sent to the people listed in the interest file. This must all be organized. The lay activity leader cooperates with the helpers who have marked the appropriate boxes on the questionnaire.

\section{Motivating the church}

Some weeks before the campaign starts, the pastor, the church elders, and the lay activities leader try to increase the motivation of the church. Reports are given about the preparation in the different areas. Experiences can be reported in place of the mission story. Sermons center around mission and outreach.. once more church members should be encouraged to bring their friends and relatives and to attend the meetings themselves. Opportunities are given for the church during the divine service to unite in prayer to ask for God's help and for the assistance of the Holy spirit. Now the campaign can start.

${ }^{1}$ In West Germany handbills are usually distributed by church members--even if it is a very large number--and are not given to the post-office. 


\section{Implementation}

Compared with the preparation, the implementation lasts only a rather short period of time. It refers only to the few weeks in which the congregational evangelistic campaign is actually carried out, and focuses on the meetings that are held. Five aspects demand the attention of the teams, the evangelism committee, and the pastor:

1. The time immediately before the meeting starts

2. The opening of the meeting

3. The presentation

4. The discussion groups

5. The time immediately after the meeting.

The Time before the Meeting starts

The team that is responsible for the presentation on a given evening needs to meet at least one hour before the meeting starts. It is necessary to go over the program once more again. Everyone must know what he is to do and when he has to do it. Some--if not all--team members are jittery. The pastor should encourage them, and in a separate room, meet with them to have a prayer session.

The helpers too must meet at least one hour in advance. All the equipment and the materials are to be prepared. Projectors, tape recorders, microphones, and all the technical parts must be checked to assure that they are working faultlessly. The helpers take a look at 
the room, the chairs, the tables, and so on. Last preparations are done.

If the small groups stay in the room where the presentation is given, chairs should be grouped around tables facing the platform. Depending on the topic, Bibles, handouts, and ball-point pens are placed on the tables. If the small groups move to another room, circles of chairs with a rather low, small table in the middle of each circle are to be arranged. The decorations are to be checked. Ushers and hostesses should move to their places. Guests often arrive rather early, and greeters can start to talk with them so they feel at ease. Church members, prepared in advance, should mingle with the people and not stay together in one bunch. Ushers and hostesses may be able to influence this to a certain degree.

The opening of the Meeting

When the meeting starts, the team presenting the message for the evening is introduced. The names of the team members and their occupations are made known. This can be done by each member of the team themselves, or by one of the team's members. Words of welcome and the introduction of the team may also be given by the head elder or the pastor. It is important to let the audience know who the team members are for the guests will have the chance to identify with the speakers. This may also 
help with the discussions that are to take place later on. People are already somewhat familiar with the speakers and dare to speak to them.

The question of whether or not to have a prayer at the beginning of the meeting arises. Some use a public prayer at once. However, if the topics are not entirely religious and have a secular touch, it may well be better to hold the prayer until the end of the meeting.

One may also start with some special music or a brief multi-media show before the team members are introduced. In any case, the introduction of the speakers is a must.

The Presentation of the Message

The presentation is itself a team effort. The number of speakers may vary. The minimum would be two speakers and the maximum five. The elements that may be used are talks, readings, music, films, slides, dramas, panel discussions, dialogues, overhead illustrations, prayers, question and answer periods, and so on. The program is many-sided and must always be interesting. This may be illustrated by an example. Below is an outline of a presentation for one meeting. The topic 
was: "Do You Need God for Dying? Or: A Matter sure as Death." The team consisted of four members. 1

outline:

1. Slides on dying and death

with background music $10 \mathrm{~min}$.

2. Song: "Making up the Balance"

(Verses 1 and 2) $5 \mathrm{~min}$.

3. Talk: "Dying without God" 8 min., Annelies

4. Talk: "Dying with God" 5 min., Evelyn

5. Song: "Making up the Balance"

(Verses 3 and 4) $5 \mathrm{~min}$.

6. Talk: "Lord, teach us to

consider that we have to die" $12 \mathrm{~min} .$, Gerhard

7. Poem: "At Night"

2 min., Evelyn

8. Talk: "No more death"

10 min., Frank

9. Poem: "The Last Party"

3 min., Katrin

10. Song: "Peace"

$3 \mathrm{~min}$.

11. Conclusion, invitation to

3 min., Evelyn ${ }^{2}$

join a discussion group,

introducing the speakers.

IIt was held on March 27, 1982, in Munich.

${ }^{2}$ This group decided to introduce the speakers --to name their names and their occupation--only at the very end of the presentation. Normally, it may be better to have this at the beginning of the meeting. 
This is a typical example of how the presentations may be made. ${ }^{1}$ The entire presentation must be smooth, therefore, practice before the campaign starts is essential. The team members have to be well prepared. They have to face the public and may not be glued to the manuscript. They must try to create an open and pleasant atmosphere. The pastor should encourage them during the presentation by his intense attention, his nodding in approval, and by other gestures.

\section{The Discussion Groups}

A very important part of evangelistic meetings of this nature-if not the most important one--is the discussion groups. 2 At the end of the presentation an announcement should be made concerning these small groups. There are pros and cons where the groups should

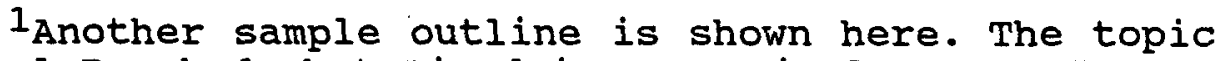
was: "Goal Reached--but Lived in a Meaningless Way."
1. Welcome and introduction
3 min., M.Dietz
2. Talk: "What Do I Live for?"
6 min., H.Wille
3. Panel Discussion: "The Meaning of Life--Different Points of View"
4. Music and slides
5. Dialogue: "Jesus and the Meaning of Life"
15 min., entire team
4 min.
18 min., H.Baumann and
Music (piano)
7. Conclusion and leading over to the discussion groups
5 min., C.Teberikler
5 min., B.Teberikler

${ }^{2}$ Concerning the importance of such conversation, see Rebecca Manley Pippert, out of the Salt Shaker \& into the World: Evangelism as a Way of Life (Downers Grove: Intervarsity Press, 1979), p. 143; Stott, pp. 70-73; Paulien, p. 36 . 
meet--in the same room or in another one. 1 In any case, the groups meet and have a leader. The teams that are responsible for the presentations prepare good questions to start the conversation. These questions may be handed to the group leaders who, in turn, ask them in their groups. The questions can also be written on overhead transparencies and brought to the screen at the end of the presentation. In both cases, the group leaders must have the questions in time to think about them and prepare for them, if necessary. However, the discussion leaders need not be alone in asking questions. The openness that has been engendered allows the members of the groups to feel free to ask questions, too. They can also make comments, even critical ones. In this case, it is important that the groups do not have a condemnatory attitude and be willing to tolerate different points of view, even if they cannot agree. This may be articulated very clearly: "We may not agree with your opinion, but we are accepting you." This acceptance helps secular people to come again and to discuss their philosophy of life and their problems within the small groups.

In each campaign efforts must be made to secure the addresses of the guests. A variety of techniques may

II personally prefer to have them meet in another room. This allows for a more open atmosphere. The guests may leave, if they wish to, but experience shows that usually they stay. They also are able to choose a group themselves. See the discussion on pp. 121-122. 
be used to reach this goal. In congregational evangelistic campaigns this is achieved rather simply. The group leader and church members who belong to the group create a kind of rapport with the visitors. Towards the end of the group session they offer in a natural way their own addresses and ask the guests for theirs. For example: "Mr. $\mathrm{X}$, we had a good discussion this evening. I would like to talk to you again. Here is my address and phone number. Would you care to put yours down on this sheet of paper? Thank you." However, each visitor should be asked only once for his address, and only church members who were able to establish some kind of personal rapport with the respective guest should ask for it. In this way, addresses are obtained easily and naturally. Even if all addresses are not obtained at the first meeting, it is not serious. Usually the guests attend the meetings more than once and another opportunity will arise. Nobody should be forced to give someone his address. The church members who were able to exchange addresses with guests should take care of their "partners" during the next meetings and perhaps even during the follow-up. They welcome them, tactfully talk to them, but should not mother them. It is not essential that the guests know at once that these persons are church members. One need not hide his one's identity, nor 
should he have to reveal it immediately. It will depend on the situation. 1

If it is appropriate, groups may close with a prayer. The dynamics within each group will be different. The leader and the church members must accommodate to this. The small group meetings need to be open-ended. Some may leave earlier, some stay rather late. If it gets too late, the leader should suggest that they continue with the topic next time, when the groups meet again after the next presentation. The groups may stay together at the next meeting or they may be formed in a different way-- with new group members. That is not a problem. Guests find the most suitable group for themselves. That they feel at home is what matters.

The Time after the Meeting

When all the guests have left, there will doubtless be a time of evaluation and of prayer. During this time joy and thankfulness are expressed for a good presentation, for good discussion groups, and for the coming of visitors. Sharing should take place. Mistakes that might have occurred should be talked over so that the program or small group sessions can be improved the next time. It is desirable to have the team responsible

${ }^{1}$ Certainly church members will make mistakes, but they will learn. Pastors make mistakes, too. 
for the next presentation paticipate during this evaluation.

Some cleaning may be necessary. Lights and heaters have to be turned off, and so on.

Even if the meeting was not a great success, the evening should end on a positive note, and with some kind of encouragement. This again is the task of the pastor.

\section{Follow-up}

A crucial part of the outreach is the follow-up to the public meetings. Often this is a very weak area. The questionnaires pointed to the fact that the participation of the church members generally drops dramatically during the follow-up. Having a good longrange preparation helps to eliminate this weakness, for laymen are prepared to care for the visitors.

\section{Definition of Follow-up}

When Protestant Christians talk about follow-up, they generally seem to refer to the work that has to be done after a person has accepted Christ as Lord and Savior. SDAs commonly take a somewhat different perspective. When they give Bible studies or help persons to have certainty of their salvation and to understand sound doctrine; when these people start to reveal a Christian lifestyle and are being integrated into the local church, this is not considered "follow-up" so much 
as "evangelism."I For Adventists follow-up hardly even begins until after baptism. The new member, for example, is invited to join a small Bible study group. He gets training to be able to win other persons for Christ and later on to teach those others themselves to win people for Christ. Protestant Christians usually have a gap between winning people to Christ and winning them for church. 2 W. B. Moore thinks of four gaps:

The gap between winning a person to Christ and getting him into the fellowship of the church... The second gap is between joining the church and being enlisted in its program... But enlisted members are not necessarily soul-winners. This is the third gap area... Winning souls is no substitute for producing reproducers, however. This is the fourth gap area in church follow-up. ${ }^{3}$

In the SDA church the first gap seems generally to be missing. Adventists are not content to have people make a decision for Christ and then to leave them alone. The final decision is established with baptism, and baptism

${ }^{1}$ Compare, however, Gary W. Kuhne, Evangelisation und was dann? Die Dynamik der persönlichen Nacharbeit (Bad Liebenzell: Verlag der Liebenzeller Mission, 1979), p. 15; James Kennedy, pp. 27, 142 and passim.

${ }^{2}$ Engel, p. 21, describes the "Here's Life America" campaign of Campus Crusade for Christ, International, and says: "More than one half million indicated they had received christ, but fewer than three percent became church members as a result." See McGavran and Arn, pp. 11-12.

${ }^{3}$ Waylon B. Moore, New Testament Follow-up--For Pastors and Laymen: How to Conserve, Mature, and Mulitply the Converts (Grand Rapids: Wm. B. Eerdmans Company, 1963), pp. 100-101. 
means also reception into church membership. Yet the other gaps are commonly present within SDA churches also.

In the context of evangelistic campaigns, however, "follow-up" would be the work that is done after the meetings are over. That is the "follow-up" of the campaign, almost irrespective of the fact that people may or may not already have made a decision for christ and/or for baptism.

Kuhne summarizes the goals of follow-up in this way: (1) assurance, (2) consistency, (3) stability, (4) Christlikeness, (5) independence, and (6) reproduction.1 Concerning the content of follow-up he points to three areas: (1) the devotional area, (2) the doctrinal area, and (3) the discipleship area. The latter area involves the training for outreach.2 The follow-up of an evangelistic campaign focuses on the doctrinal and the devotional area. Only after baptism, are people trained for outreach.

\section{Kinds of Follow-up}

The follow-up of the congregational evangelistic campaign--which also deals with the doctrinal and the devotional area--can be done in different but mutually

\footnotetext{
$1_{\text {See Kuhne, p. } 75 .}$

${ }^{2}$ Ibid., pp. 79-90.
} 
supplemental ways: (1) personal follow-up, (2) follow-up by church programs, (3) follow-up by public programs. The personal follow-up is done by church members and the pastor. Not only the pastor but also and mainly church members should visit guests; they should seek to arrange continuing Bible studies with them, invite them into their own homes, and lead out in Bible study groups and other small groups. Thus, the personal follow-up centers in the homes of guests or church members not in the church or a public building.

The follow-up by church programs may include invitations to programs which the church carries out mainly for its own members and for guests, such as divine services, baptismal services, retreats, feasts, and concerts. It centers in the church and in the church building.

Public programs are programs especially designed by the church to focus on the public and not on church members. The follow-up by public programs may include seminars and evangelistic campaigns of a different nature. This must be planned beforehand so that the follow-up is secured. One should not be taken by surprise and not know how to continue with the guests. Persons who were baptized should participate in these kinds of follow-up in the same way those not yet baptized do. They need to be grounded in Christ--in the 
devotional and doctrinal areas. In addition, they need training in how to witness and in other areas. Usually they are very willing to get involved in the outreach of the church and even demand training.

\section{The Actual Follow-up}

All three ways of follow-up mentioned above are important. If any kind must be omitted it should only be the area of public programs. Personal follow-up must not be omitted. The follow-up by church programs is very natural, too, since the church normally has its programs anyway .

During the campaign addresses of guests would have been collected. At the end of the meetings all addresses are at hand. Another list should reveal those who have made contacts with the guests.

1. Follow-up by public programs. Towards the end of the series of meetings, a further campaign or a seminar which follows the congregational evangelistic campaign should be announced. Handbills are distributed to the audience. The visitors may receive a special letter which reinforces the invitation again. The advertising should not be restricted to the guests of the congregational evangelistic campaign. Other persons are invited, as well. But interest is centered mainly on the guests who have attended the first campaign. If possible, the new speaker or the speakers should be introduced 
during the congregational evangelistic campaign. It would be good to have them participate in this campaign to assure continuity.

2. Follow-up by church programs. The invitation to church programs also can be given towards the end of the campaign. It can also be extended in written form. The church may invite the guests to its regular program. It may schedule specific programs to meet the needs of the visitors, for example, a special divine service. Social activities often help guests to get to know the church members and to feel accepted and received into the fellowship of the church. A retreat may be of great value. Guests of such a retreat are able to mingle freely with church members and vice versa. Guests that are already baptized need training classes. Follow-up by church programs should not be missing.

3. The personal follow-up. The most important area is personal follow-up. This cannot be replaced by any other type of follow-up. It must take place, no matter what. Visitation may already have been started during the campaign. Immediately after the end of the effort, the lay activities leader and the pastor should meet with the group who were trained before the campaign started, the church members who already have made contacts with guests, and church members who are willing and seem able to take over the interests. Names and 
addresses can then be distributed and information given on how to make calls, how to give Bible studies, and how to invite people to small groups. To give Bible studies regularly and to assimilate the guests in small groups, thereby leading people to baptism and personal growth, is the goal of personal follow-up. The better this is done, the greater the number of baptismal candidates. The church members who have taken over interests should be asked to give feed-back to the lay activities leader, who is responsible for supervision. From time to time there should be meetings with this group to exchange experiences, to provide help and support, and to give encouragement. Some guests may draw back. New addresses may be distributed. The interest file must be kept up-todate. People who no longer get Bible studies are still candidates for invitations.

It is important to notice that there are different types of personalities: those who are willing to study the Bible at home, but not willing to attend public meetings; those who are willing to attend public meetings, but not willing to study the Bible at home; and those who are interested both ways. This insight encourages one when the follow-up does not work as one expects it to work. The church should try to have a program that is as good as possible. The follow-up is the most crucial part of the effort; it secures decisions, it determines 
if and how the next campaign will be done, and it is essential for the process of multiplication and reproduction.

\section{Local Evaluation}

Shortly after the campaign is over the evangelism committee should meet for an evaluation of the meetings. This should be done within two weeks after the effort to gain fresh impressions. The statistical data need to be gathered and the financial clearance finished by this time. An evaluation sheet may help all important areas concerning the campaign to be considered. Suggestions for an evaluation sheet include:

1. Did the church reach its objectives? What were the problems?

2. Did the church reach the target group it was aiming at? Why or why not?

3. How did the preparation of the church work? What about the preparation of the meetings and the preparation of the public?

4. Which problems did the church have with the implementation? What about the themes of the presentations and their quality?

5. How many guests attended the meetings? What was the highest number of guests per meeting? What was the topic of this meeting? What was the average 
attendance of guests? What was the total number of visitors?

6. By what means were most of the guests reached?

7. How is the follow-up working? What about the participation of the church in each phase?

8. What was the outcome regarding finances?

9. Which positive effects on the church and on guests could be observed?

10. Other remarks? ${ }^{1}$

The result of this evaluation must then be studied by the church board. The evangelism committee may give recommendations and suggestions regarding a further campaign. It may suggest planning another evangelistic campaign for the next year. The church board should discuss the result of the evaluation and the recommendations of the evangelism committee. It may make decisions regarding the next campaign. In a church business meeting a report on the campaign should be given and suggestions for new action plans are to be talked over. Final decisions are to be made.

The evaluation process is essential to improve further programs and to lay plans for the next campaign. The pastor must give honest encouragement about the job

Isee A Pastor's Guide to Materials for Use in The caring Church (Arroyo Grande: Concerned Communications, n. a.), p. 18. It is suggested that one use a seminar participant questionnaire for evaluating seminar effectiveness. 
that was done and the one that still is to be done. The results of the evaluation and the recommendations should be brought before the entire congregation. The church will thus again realize its ownership of the campaign and its responsibility for the outcome and for further efforts. Ownership of a new program can thus be established.

\section{Combination with other Programs}

Congregational evangelistic campaigns should be combined with other public programs. In the beginning a church may have only a short congregational evangelistic campaign to get used to this type of work. Later, it is essential to insert it into sequence evangelism. "Sequence evangelism consists of such things as felt-need seminars, bridge seminars, response seminars or a public campaign, and nurture seminars."1 By their very nature, congregational evangelistic campaigns are generally

\section{$1_{\text {See Sequence Evangelism Seminars (Arroyo }}$} Grande: Concerned Communications, n.d.), p. 5. In this booklet several examples for the different stages of evangelism are listed. Felt-need seminars include programs such as: weight control, cooking school, and parenting. One should add at least stop-smoking programs. Bridge seminars would include programs for resolving stress and time management. Response seminars: "How to Make Christianity Real," "Studies in Daniel," "Studies in Revelation," "Lifespirit." Nurture seminars: "The Way to Adventist Church Growth," "How to know God," "Learning to Love," "Fundamentals of Adventism," "Coming Events." See also Hector Hammerly, "A Strategy for Public Evangelism," in Meeting the Secular Mind: Some Adventist Perspectives, ed. Humberto M. Rasi and Fritz Guy (Berrien Springs: Andrews University Press, 1985), p. 112. 
spiritual. They may cover health topics, psychological topics, or theological questions. In any case, they contain the element of witnessing. There are different options for congregational evangelistic campaigns to be inserted into sequence evangelism:

1. If they are, for example, health oriented, they may be part of the felt-need seminars or may be the only felt-need seminar a church conducts. Bridging seminars and a public campaign should follow. However, it may be more natural to use congregational evangelistic campaigns as bridging seminars. In any case, this type of campaign may be one of many seminars which lead to the major public campaign conducted by a professional evangelist.

2. Congregational evangelistic campaigns can be used as follow-up of a major campaign. In other words, they may take the place of nurture seminars.

3. The congregational evangelistic campaign may also follow the felt-need seminars and the bridging seminars. In this case, the response seminar is not a campaign held by the professional evangelist but a congregational evangelistic campaign. This option is the closest one to the model described above.

The local church must decide how its sequence evangelism is to be designed and where the congregational evangelistic campaign should be inserted. Then the overall program will be more successful. 


\section{CHAPTER IV}

\section{CONCLUSIONS AND RECOMMENDATIONS}

\section{Benefits of Congregational Evangelistic Campaigns}

This chapter again emphasizes the benefits of congregational evangelistic campaigns and includes a number of recommendations. The benefits of this type of outreach are manifested in three areas: benefits for the church, for the guests, and for the team members.

\section{Benefits for the Church}

A congregational evangelistic campaign is a group experience, for a large percentage of the congregation is actively involved in the campaign. The church thus realizes that it is able to reach people by public efforts without the direct help of an employed professional. The common goal causes the church members to get closer to each other. This creates a special atmosphere of fellowship and a united attempt to reach people for Christ. A new spirit of mission often arises from the experience.

The increased fellowship is due to the team work that is necessary to conduct this type of campaign. Team 
work demands small groups working together. Preparing a congregational evangelistic campaign means that small groups come into existence almost automatically. Existing small groups become more task-oriented. This may enliven these small groups. Normally the church also gets a new vision about the importance and the blessings of team work. This insight may affect the work that is done within the church in the different departments.

Congregational evangelistic campaigns also produce a climate of expectancy and growth. There is little time for internal fights. "I never saw a church so busily engaged with public evangelism as in this work. This impression was verified with further campaigns," one pastor wrote. The church is activated. Its spiritual life, service, and--as mentioned before--its fellowship are enlivened. It gets a new idea of what mission and evangelism is today.

\section{Benefits for the Guests}

The presentations within the congregational evangelistic campaign are by their nature variegated. There are different approaches and a somewhat different format at almost every meeting. The brief talks, the discussion groups, the opportunity to get acquainted with one another--in short, the open style--attracts people and reaches, to a certain degree, secular man. The guests 
enjoy coming back again to see and to hear the next meeting. They are not afraid of pressure and do not experience coercion, although they are called to make decisions.

Since the campaign is held by laymen, guests are able to identify with them. The christian laymen are people who experience the same problems they do. But in spite of the drudgery of every-day life, these lay persons are living a Christian life and enjoying a higher quality of life. This is fascinating to the guests. The testimony of laymen has a strong influence on them. And it is really a great advantage for guests and speakers to meet informally after the presentation and to get to know each other.

As a result of this open atmosphere and fellowship with the guests, baptisms may be expected. one pastor who participated in congregational evangelistic campaigns wrote in an evaluation: "We had the joy of seeing some of the guests of this first congregational evangelistic campaign baptized one year later during the next one. This was repeated the following year."

\section{Benefits for the Team Members}

Team members also reap important benefits. Especially they have an opportunity to use their spiritual gifts. Here is a whole field in which to exercise them, and team members are able to get some important 
experiences. They may perceive some success and even become more enthusiastic because of it. Their personal Christian development and their growth process are promoted, and their spiritual life is enhanced.

An initial congregational evangelistic campaign is likely to be a sort of preparation for larger campaigns. Some laymen will probably be able and willing to take over an entire presentation without someone else to assist them. One further step is the conducting of an entire campaign by oneself.

The close relationship with the guests is very rewarding. It is easy to meet them and to be interested in them. Witnessing, praying, and follow-up are then rather natural.

It is valuable for team members to work together with other church members; it is rewarding for them to come close to each other. Sometimes team members even regret when the campaign is over. In any case the congregational evangelistic campaign benefits all parties.

Recommendations Concerning congregational Evangelistic Campaigns

Some recommendations pastors and laymen should consider are:

1. As a result of this study I am convinced that it becomes very important for pastors to put more trust 
in their laymen. The laymen have gifts and abilities bestowed on them by God. Pastors must not despise or undervalue what God has given to men. The pastor must not be a do-it-yourself man. The church needs to be able to survive even without pastor. To a great degree, the church should be independent of its pastor, and the pastor should not fear the activities of the church.

2. As a result of this study $I$ am convinced that the training of laymen is sadly lacking. Here is an area for vast improvement. However, the training must not be merely theoretical. This has often been too much the case. Laymen need practical training in addition to theoretical training. They must practice giving Bible studies, preaching sermons, conducting sabbath school classes, first in small groups and later in a larger circle. Pastors have often been content to hand out a book to their laymen on how to preach sermons, rather than sitting down with them and working hard to help them to be just as successful as the pastors. Pastors must not be afraid when laymen are doing better than they are. On the contrary, it is an honor for a pastor to have welltrained and outstanding, laboring laymen. Training takes time and effort. It is easier for the pastor to give a Bible study or to conduct a seminar himself--and pastors are often even more acknowledged by the administrative leadership for doing this than for training laymen. But 
if the pastor really wants to promote the proclamation of the gospel, he must train the laity. Thus, each pastor is urged to train the church members, using the best materials and the best methods and putting all his heart into this task.

3. I am convinced that laymen need to be permitted to preach sermons. They may make mistakes, but pastors fail sometimes, too. The pastor is not the center of the church, he is the trainer. When laymen start to preach good sermons, oftentimes the church begins to awake from its sleep.

4. Again, I am convinced that pastors should have the laity conduct their own congregational evangeIistic campaign. Even if the church gets somewhat independent from the pastor, the pastor is, nevertheless, the supervisor. When church and pastor have mutual respect, they work together more harmoniously.

5. Finally, I am convinced that when the church is allowed to be active in these ways, it is prepared to perform even greater tasks. The church may start to conduct a lay evangelistic campaign by itself; it may start to plant another church. Thus God's "frozen people" may be released.

on the other hand, sometimes the church has to take the initiative. It has to move ahead. A world is to be won for Jesus Christ. This is the task of the church. 
The means for winning the world are to be found in the Christian life-style of the church members ${ }^{1}$, the social action of the congregation, and the proclamation of the gospel both privately and publicly.

I strongly urge churches to forge ahead, to try this approach--in West Germany and perhaps also in other parts of the Western world.

"The Christian message is the most relevant of all announcements to a modern world."2 The proclamation of this message has to be done by the entire church and not just by professionals.

\section{Benefits Gained from This Project}

Benefits I personally gained from this project are:

1. New insights in public evangelism. As a pastor one is oftentimes so busy that one neglects to study carefully the subject of evangelism. One may feel that no time is left to reflect on a previously conducted campaign or to compare the effectiveness of different kinds of campaigns. By this project I was forced to take a closer look at evangelism in general and at all aspects of congregational evangelistic campaigns. This proved to

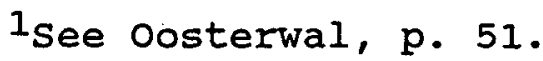

${ }^{2}$ Augsburger, p. 12 .
} 
be very beneficial. I am totally convinced that evangelism is a must.

2. New insights into the secular mind set. Since in West Germany we have to deal with secular people extensively, it was important better to get to know their mind set and to understand problems and opportunities we have in trying to reach them. I feel this was also achieved by reading several books and by discussing this subject with colleagues.

3. An enlarged vision of a laity-centered church. Certainly, Christ is the center of his church. In talking about the laity-centered church I want to lay the emphasis on the laity instead of the pastors to administer the church and to promote the proclamation of the gospel. This does not deny the sovereignty of Jesus Christ. This project helped me to get an even clearer vision of the importance of the laity.

4. An enlarged vision of a mission-oriented church. The church has to be mission-oriented in all its programs. Plans have to be adopted by the local church which do not only maintain a religious club but focus on missionary goals. My vision of a mission-oriented church was reinforced by this study. When one of my churches recently worked on a five-year plan, we set goals in various areas of church activities. When we made 
programs, however, we--that is the entire congregation-only dealt with the area of outreach. The planning process for the other areas were left to the respective departments.

5. An enlarged vision of the importance of training lay people. In my opinion, this is the key for successful congregational evangelistic campaigns and for the fulfillment of the Great commission. It was never clearer to me than after this study that we cannot do without the laity. But the laity needs training in order not to be frustrated and to turn its back on the proclamation of the gospel.

6. The establishing of a training program. Probably this was the most essential benefit I gained from the project. As far as I can see now, this training program seems to work very well.

7. Positive results with the implementation of the training program. After the large campaign recently held in Munich and some of the follow-up campaigns conducted by the local conference evangelist were over, I chose a group of church members in each of my churches to be trained in various fields. This was in fall 1986. Although I told these church members that besides the group sessions homework had to be done, almost everyone responded positively and was willing to participate. Two training groups were started then. One group 
member left because of personal and family problems, another--a lady--gave birth to a baby and, therefore, had to leave the group. Some persons came only for one specific seminar, for example, "Teaching Sabbath school Lessons." But several other persons joined the groups later on, although I tried to limit the seize of the groups. In any case, the groups were fairly stable. They numbered twenty-four members. 1 The average attendance with twenty meetings was sixteen church members which is really good because some were sick or were out of town when the group meetings took place. Twenty-two persons participated in the seminar "Preaching sermons". The average attendance was an even eighteen group members per session. Ten of the twenty-two group members have already preached short sermons. Others have already gotten a date to preach their sermons. Sixteen group members work with "The Bible says" study guides or give Bible studies. The following topics were covered: preaching sermons, teaching Sabbath school lessons, skills of listening and caring, ${ }^{2}$ world mission, as well as giving Bible studies, and the history of the Adventist church. When we recently worked on our five-year plan for

${ }^{1}$ The larger church of my district numbers 139 church members and the smaller one 63 church members.

2 "Skills of listening and caring" was a weekend seminar and is not counted with the twenty meetings mentioned above. 
the larger church, group members spontaneously suggested having two congregational evangelistic campaigns within the next years, although I had not even mentioned it. They also wanted to conduct Daniel seminars and other types of seminars. These positive results are encouraging.

In conclusion, I must confess that I am very enthusiastic about congregational evangelistic campaigns. I want to continue working in this direction to mobilize the church and to promote the proclamation of the gospel. Training and team-work must be key-words in my ministry in the future. And certainly improvements will be necessary with each campaign that is conducted. 
APPENDIX 1

\section{Letter to Ministers}

Dear Fellow Minister:

Since I am working on a project for Andrews University which deals with congregational evangelistic campaigns in West Germany I ask you cordially to answer the short attached questionnaire with only two questions and to return it to me as soon as possible.

A congregational evangelistic campaigns as here defined is an evangelistic effort conducted by the lay congregation and not - as traditionally - by the pastor or an professional evangelist. The campaign is prepared and implemented by the church itself and by groups of laymen under the supervision of the pastor.

I already want to thank you for your help and support. May our Lord bless you in your ministry. sincerly yours

(Ekkehardt Müller) 
Questionnaire on Congregational Evangelistic Campaigns

Please, mark the appropriate item.

1.) Have you ever pastored a church which conducted a congregational type of evangelistic campaign?
- Yes
- No

2.) In how many congregational evangelistic campaigns did you participate?
$\circ 1$
$\circ 2$
- 3-5
- more than 6

Thank you for your help.

(Name)

(Address) 
APPENDIX 2

\section{Letter No. 2 to Ministers}

Dear Fellow Minister:

You do belong to the group of ministers who participated in congregational evangelistic campaigns (campaigns prepared and implemented by the lay congregation and not by the pastor). To gather further information on this topic - how it. was done and how successful it was - I would like to ask you to answer a second questionnaire containing 20 questions.

In order to keep it as little time-consuming as possible almost all the questions are asked in a way that you only have to mark the appropriate boxes. As you easily will discern, some questions allow of more than one answer. The empty space is provided for further remarks in the case it should be necessary or desirable. only with the last two questions you are asked to give some comments.

I want to express my appreciation for taking the time and filling out this questionnaire. It is really of great help for me. Thank you very much too for returning 
it soon. Wishing you peace and joy in the Lord and blessings in your ministry, sincerly yours (Ekkehardt Müller)

(In the case that you participated in more than one congregational evangelistic campaign, please, choose one or two that are representative of all the others.) 
Questionnaire No. 2 on Congregational

Evangelistic Campaigns

1. When has your church conducted this type of campaign?
- 0-2 years ago
- 3-5 years ago
- 6-10 years ago
- more than 10 years ago

2. How many meetings did you have?
- 1-5
- 6-10
- 10-15
- more than 15

3. Where did you have this campaign?
- own church building
- rented church building
- public building

4. What is the size of your church?
- up to 50 members
- up to 100 members
- up to 200 members
- more than 200 members 
5. What were the reasons to choose this type of campaign?

- to try new methods

- the persuasion that laymen are more easily accepted by unbelievers than clergymen

- the assumption that the church would be revived through this effort

- the explicit desire of the church

- my own desire

- it was time to have an evangelistic campaign again

$\circ$

o

6. Which objectives did you have?

- no specific goals

- to reach more people

- to activate the church

- to baptize SDA-children

- to baptize Non-SDAs and SDA-children

$\circ$

$\circ$ 
7. Which target group did you choose?

- no specific target group

- an age group:

- youth

- young couples

- middle age

- old age

- a social-economic class:
- lower class
- middle class
- upper class

- a class having a certain education
- elementary school
- lower grade secondary school
- high school
- university

- a minority

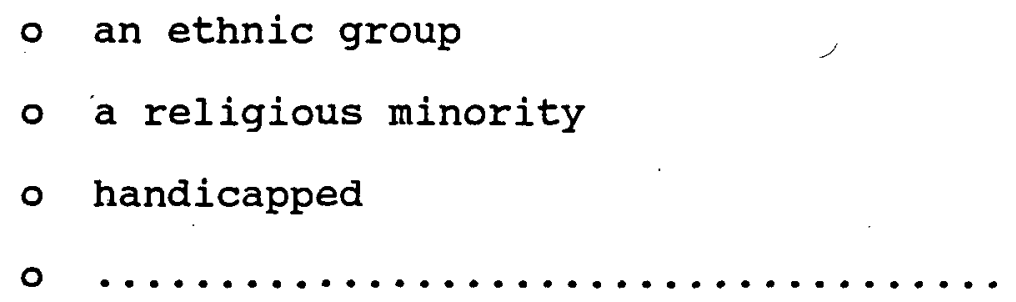

- all of them

$\circ$ 
8. What elements of preparation did you use?

a. Preparation of the church

- church business meetings

o sermons

- seminars of a general nature

- training seminars

o retreat

- week of spiritual emphasis

o working on a mission statement

- goal setting

- other types of campaigns to get used to public evangelistic campaigns

o' organization of the circle of helpers

- selection of the speakers

0

$\circ$

b. Financial arrangements

- fees from the participants

- offerings during the campaign

- payment by the local conference

- church paid for outreach

0

$\circ$ 
c. Program for the meetings

- selection of the main theme of the entire campaign (by a committee)

- formulation of the themes for each meeting (e.g. by a committee or a small group)

- preparing the program for each meeting (in small groups)

0

$\circ$

d. Preparation of the public

- advertisements in newspapers

- mailing handbills

- distributing handbilis

- door-to-door outreach

- personal invitation by church members

- invitation of persons getting Bible studies

- invitation of persons participating in small groups

- bills

- public programs such as

- Five-day-plan

- health seminar

- cooking school

- Daniel Seminar

- Revelation Seminar

- concerts

$\circ$

0 


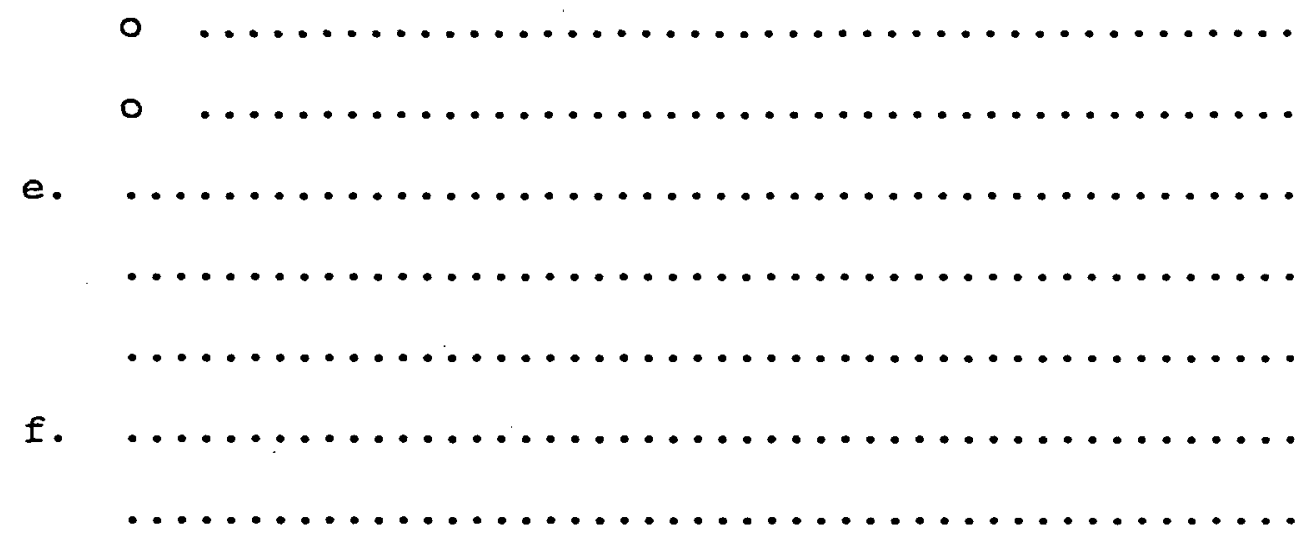

9. What about the implementation?

a. The meetings were structured by

- talks

- music

- films, slides, multi-media shows

- drama

- panel discussions

- dialogues

- overhead illustrations

- prayers

- question and answer periods

o

o

b. The meetings consisted of

- a public proclamation only

- a public proclamation and discussions in small circles 
The small circles

- met in the same room

- met in another room

- had soft drinks and cookies

- had no soft drinks and cookies

- were formal

- were informal

o

0

c. The themes of the meetings dealt primarily

- with contemporary problems (e.g. health, family, psychology, politics)

- with biblical topics

- with prophecy

o

0

d. The average number of persons involved in the proclamation from the platform per meeting was
- 1 person
- 2 persons
- 3-5 persons
- more than 5 persons

e.

f. 
10. What about the follow-up?
- visits to the guests in their homes
- Bible studies in their homes
- Bible study groups
- hospitality and friendship
- other types of evangelistic campaigns
- other public programs (e.g. seminars)
- invitation to the worship service
- invitation to a baptismal service
- invitation to a retreat
- invitations to feasts of the church, concerts, etc.

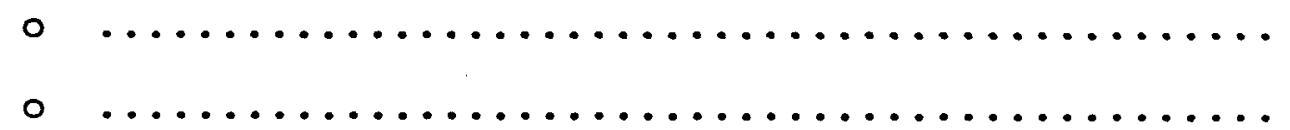

11. How did the church participate?

a. In the preparation

- up to $5 \%$ of the members

- up to $10 \%$ of the members

- up to $20 \%$ of the members

- up to $30 \%$ of the members

- up to $50 \%$ of the members

- up to $80 \%$ of the members

- more than $80 \%$ of the members 
b. In the implementation

- up to $5 \%$ of the members

- up to $10 \%$ of the members

- up to $20 \%$ of the members

- up to $30 \%$ of the members

- up to $50 \%$ of the members

- up to $80 \%$ of the members

- more than $80 \%$ of the members

c. In the follow-up

- up to $5 \%$ of the members

- up to $10 \%$ of the members

- up to $20 \%$ of the members

- up to $30 \%$ of the members

- up to $50 \%$ of the members

- up to $80 \%$ of the members

- more than $80 \%$ of the members

12. How many Non-SDA visitors did you have?

a. Highest number at one meeting
o up to 5
- up to 10
- up to 20
- up to 50
- more than 50 
b. Average number of guests per meeting
- up to 5
- up to 10
- up to 20
- up to 50
- more than 50

c. Total number of guests in the campaign
- up to 10
- up to 20
- up to 30
- up to 50
o up to 70
- up to 100
- up to 150
- up to 200
- more than 200

13. By what means were most of the Non-SDAs reached?

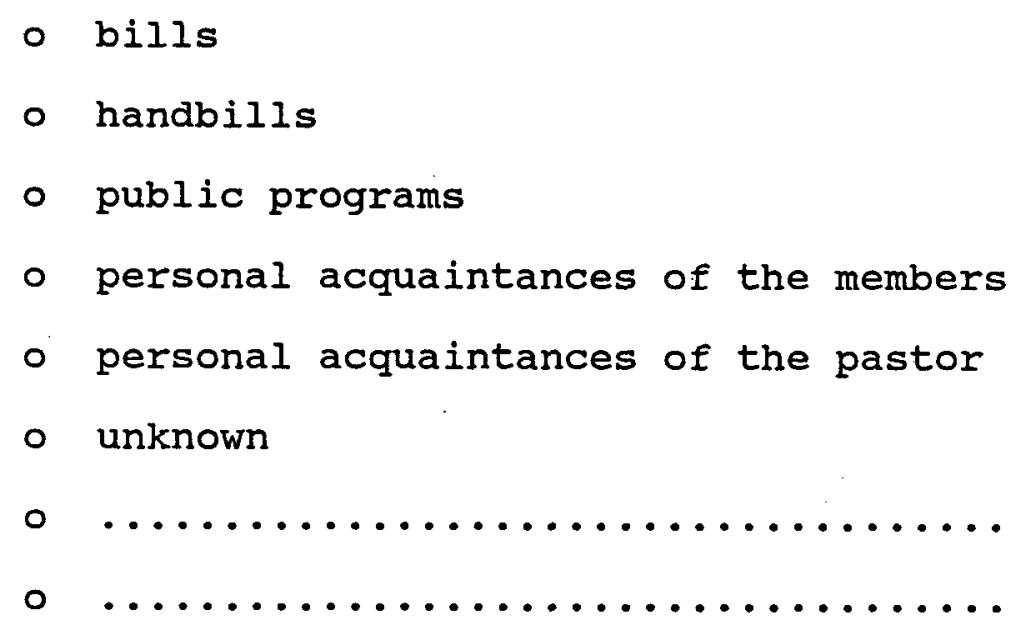


14. Which positive effects on the church did you observe?

- no positive effects

- increased Sabbath school attendance

- increased worship service attendance

- increased income in tithe and offerings

- new small groups

- new activities to support fellowship

- new social activities

- new evangelistic campaigns

o

0

15. Which positive effects on the Non-SDAs did you observe?

- no positive effects

- new relationships to SDAs

- deeper relationships to SDAs

- Bible studies in homes possible

- Bible study groups joined

- attendance at worship service

- attendance at other programs

- decisions to be baptized

$\circ \quad \ldots \ldots \ldots \ldots \ldots \ldots \ldots \ldots \ldots \ldots \ldots \ldots \ldots \ldots \ldots \ldots \ldots \ldots$

$\circ$ 
16. What is the church's opinion about congregational evangelistic campaings?

- very enthusiastic

- mildly enthusiastic

- neutral

- discontented

o strictly against it

17. What is your own opinion about congregational evangelistic campaigns?

- very enthusiastic

- mildly enthusiastic

- neutral

- discontented

o strictly against it

18. What do you think about congregational evangelistic campaigns as compared to traditional evangelistic efforts?

- much more successful

- more successful

- similar

- less successful

- much less successful

Remarks : $\ldots \ldots \ldots \ldots \ldots \ldots \ldots \ldots \ldots \ldots \ldots \ldots \ldots \ldots \ldots \ldots \ldots \ldots$

- I would lead out in another one.

- I would not lead out in another one. 
19. What were the weaknesses in your opinion?

a. Preparation:

b. Implementation:

c. Follow-up:

20. What would you do differently, if you had to participate in another congregational evangelistic campaign?

Thank you for your help.

(Your name)

(Your address) 
APPENDIX 3

\section{Questions for the Interview}

1. Today it is our challenge to reach secular man. In what way do congregational evangelistic campaigns contribute to get to this goal?

2. What do you think about the assumption that congrega-

tional evangelistic campaigns are less threatening to guests than traditional ones are?

3. Almost all the congregational evangelistic campaigns were held in church buildings. What is your opinion about using public halls?

4. Some churches do not use public prayer right from the beginning of a congregational evangelistic campaign. At what point is it best to start praying publicly?

5. The small groups may already sit around tables all the time during the proclamation of the message and may stay in the same room for their discussions, or they may meet in another room for discussions after the proclamation is over. In which direction do you tend to go and what is the reason for this decision? 
APPENDIX 4

\section{The Preparation of the church}

My Participation in the Evangelistic Campaign

God has called all of us for service. I am thankful that he is trusting in me. I want to use my gifts and talents. I am willing to collaborate with the evangelistic campaign in the following areas: (Please, mark the appropriate boxes.)

\section{Preparation}

- praying daily for the campaign

- attendance at the prayer meeting in the church

- attendance at the meetings of a prayer group

- starting a prayer group myself

- starting another small group

- providing addresses for the interest file

- inviting friends, acquaintances, and relatives

- mailing handbills and writing envelopes

- distributing handbills

- getting materials

- handing in ads

- financial support

$\circ$ 


\section{Implementation}

- working with a group that prepares and presents the program of a meeting by talks, drama, announcements, and so on

- leading a discussion group

- contributing by special music

- service as usher or host/hostess

- hat-check service

- responsible for the technical equipment

- responsible for the decoration of the room

- cleansing the room

- transportation service

- taking pictures

- waiting at the tables

- attending the meetings

- responsible for the statistics

0

\section{Follow-up}

- writing an article about the campaign for the denomi national paper

- making an analysis of the campaign

- financial clearing

- visiting guests

- giving Bible studies

- inviting guests in one's home

- starting small groups with interests 
- attending small groups

- attending further public meetings of the church and inviting friends to come to these meetings

- participating in a retreat and inviting friends to the retreat

$\circ$

"Ask and it will be given you; seek and you will find; knock and the door will be opened to you. For everyone who asks receives; he who seeks finds; and to him who knocks, the door will be opened." (Matt 7:7-8) God will bless us, when we start to work together, and we will draw nearer to each other. The evangelism committee appreciates all the suggestions that will be made.

(my name) 


\section{Invitation List for the Evangelistic Campaign}

Dear Brothers and Sisters:

As part of the preparation of our campaign we want to establish an interest file. Certainly you want to invite your interests, neighbors, and friends personally. But there are probably other persons you know, who should receive a mailed invitation. Therefore we ask you to provide the following information:

1. Please list under (1) those persons, whom you want to invite personally.

2. Please list under (2) the addresses of persons, whom we are to invite by by a letter and a mailed handbill.

3. Mark all persons with an (*) from whom you know or suppose them to attend the meetings.

Date: Please, return this list until ..... to the lay activities leader or the head elder.

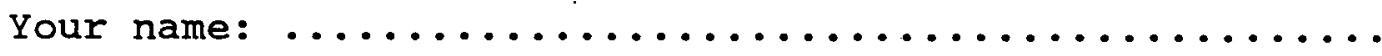

(2) 
Please, pray daily in behalf of our campaign and ask God that our friends will attend the meetings. As church we want to set a good example by attending the meetings faithfully, too. Please, copy the list when it is filled out and use it as a prayer list. 
BIBLIOGRAPHY

Administry, Summer 1984.
Administry, winter 1984.
Administry, winter 1985.

Adventist Men - Lay Activities Leaflet No.15. Washington, D.C.: Lay Activities Department, General Conference of Seventh-day Adventists, 1976.

Aldrich, Joseph C. Life-style Evangelism: Crossing Traditional Boundaries to Reach the Unbelieving World. Portland: Multnomah Press, 1981.

"Lifestyle Evangelism - winning through Winsomeness." Christianity Today 27 (1983):13-17.

Allen, Jimmy R. "A Society of Innkeepers." Southwestern Journal of Theology 17 (1975): 9-19.

Aller Diener. Stoffsammlungen und Mitteilungen der EAD-Predigtamtsabteilung. Bern: Gemeinschaft der Siebenten-Tags-Adventisten, Euro-Afrika-Division, 2 (1977).

Aller Diener. Stoffsammlungen und Mitteilungen der EAD-Predigtamtsabteilung. Bern: Gemeinschaft der Siebenten-Tags-Adventisten, Euro-Afrika-Division, $3 / 4$ (1981).

Amstutz, Josef. "Theologische überlegungen zum Thema Mission und Laie." In Das Laienapostolat in den Missionen - Festschrift Prof. Dr. Johannes Beckmann SMP zum 60. Geburtstag dargeboten von Freunden und Schülern. Edited by Johannes Specker and P. Walbert Bühlmann. Schöneck-Beckenried: Administration der Neuen Zeitschrift für Missionswissenschaft, 1961 .

Arn, Winfield. ed. The Pastor's Church Growth Handbook. 2 vols. Pasadena: Church Growth Press, 1982. 
Arteaga, Antonio. "A Study of an Evangelistic Approach for Catholics and the Nonreligious Based on E. G. White's Writings." B. A. thesis, Andrews University, 1968 .

Augsburger, Myron s. Invitation to Discipleship: The Message of Evangelism. Scottdale, Pa.: Herald Press, 1964 .

Autrey, C. E. Basic Evangelism. Grand Rapids: Zondervan Publishing House, 1959.

- Evangelism in the Acts. Grand Rapids: Zondervan Publishing House, 1964

Ayer, William Ward. Flame for the Altar. Grand Rapids: Zondervan Publishing House, 1952.

Baker, John. "The Priesthood of All Believers. Reunion: Theological Explorations, 2." Theology 69 (1966): 60-65.

Bauer, J. B. "Könige und Priester, ein heiliges Volk (Ex $19,6)$." Biblische Zeitschrift 2 (1958):283-286.

Bauer, Walter. Griechisch-Deutsches wörterbuch zu den Schriften des Neuen Testaments und der übrigen urchristlichen Literatur. 5th ed. Berlin: Verlag Alfred Töpelmann, 1963.

Beaven, Albert W. "The Local Church and Evangelism." In The Message and Method of the New Evangelism: A Joint Statement of the Evangelistic Mission of the Christian Church. Edited by Jesse M. Bader. New York: Round Table Press, 1937.

Bertram, Georg, and Schmidt, Karl Ludwig. "Ethnos." Theological Dictionary of the New Testament. Edited by Gerhard Kittel and Gerhard Friedrich. Grand Rapids: Wm. B. Eerdmans Publishing Company, 1983. 2:364-372.

Best, Ernest. "Spiritual Sacrifice. General Priesthood in the New Testament." Interpretation 14 (1960): 273-299.

Beyer, Hermann Wolfgang. "Diakoneo." Theological Dictionary of the New Testament. Edited by Gerhard Kittel and Gerhard Friedrich. Grand Rapids: Wm. B. Eerdmans Publishing Company, 1983. 2:81-93. 
Beyreuther, Erich. Kirche in Bewegung - Geschichte der Evangelisation und Volksmission. Berlin: Christlicher Zeitschriftenverlag, 1968.

Blatherwick, Douglas Pursey. A Layman Speaks. London: The Epworth Press, 1959.

Bock, Lowell L., and Rasi, Humberto M. "Report and Recommendations to the General Conference Committee." In Meeting the Secular Mind: Some Adventist Perspectives. Selected Working Papers of the Committee on Secularism of the General Conference of Seventh-day Adventists 1981-1985. Edited by Humberto M. Rasi and Fritz Guy. Berrien Springs: Andrews University Press, 1985.

Bresee, Floyd. "Layman's Lib." Worker, May-June 1986, pp. 18-20.

Brister, C. W. People who Care. Nashville: Broadman Press, 1967.

Brown, Henry Clifton. Messages for Men. Grand Rapids: Zondervan Publishing House, 1960.

Brox, Norbert. Der erste Petrusbrief. Evangelischkatholischer Kommentar zum Neuen Testament. Neukirchen-Vluyn: Neukirchener Verlag, 1979.

Bruce, F. F. Commentary on the Book of Acts. The New International Commentary on the New Testament. Grand Rapids: Wm. B. Eerdmans Publishing Company, 1954 .

The Epistle to the Ephesians: London: Pickering \& Inglis, 1961.

Bultmann, Rudolf. Theologie des Neuen Testaments. Tübingen: J. C. B. Mohr (Paul Siebeck), 1953.

Butt, Howard, ed. At the Edge of Hope: Christian Laity in Paradox. New York: Seabury Press, 1978.

Calloud, Jean, and Genuyt, François. La Prèmieré Épitre de Pierre - Analyse Sémiotique. Lectio Divina 102. Paris: Les Éditions du Cerf, 1982.

Campbell, Thomas Charles, and Fukuyama, Yoshio. The Fragmented Laymen. Philadelphia: Pilgrim Press, 1970 . 
Cardijn, Joseph. Laymen into Action. Chicago: Y. C. W., 1964 .

Caring Church--A Strategy for North America, The. Prepared by the North American Division of the General Conference of Seventh-day Adventists in cooperation with the center of Continuing Education for Ministry. Washington, D.C.: Review and Herald Publishing Association, 1983.

Cerna, Miguel A. "Small Groups That Care Makes a Church That Grows." Administry, Summer 1983, p. 10.

Chastain, Theron. We Can Win others: A Program of Evangelism for Present-Day Churches. Philadelphia: Judson Press, 1953.

Chevallier, Max-Allain. "l Pierre $1 / 1$ à 2/10. Structure Litéraire et Conséquences Exégétiques." Revue d'Histoire et de Philosophie Religieuses 51 (1971):127-142.

Cho, Paul Yonggi. Successful Home Cell Groups. Plainfield: Logos International, 1981.

Coates, Thomas. "Some Reflections on the Mission of Christ in Asia." Currents in Theology and Mission 3 (1976): 35-44.

Coleman, Robert E. Des Meisters Plan der Evangelisation. Neuhausen-stuttgart: Hänssler-Verlag, 1984 .

Congar, Yves M. J. Lay People in the Church. A Study for a Theology of Laity. Westminster: Newman Press, 1967 .

Conzelmann, Hans. "Der Brief an die Epheser." Die Briefe an die Galater, Epheser, Philipper, Kolosser, Thessalonicher und Philemon. Das Neue Testament Deutsch. Göttinger Bibelwerk. Edited by J. Becker, H. Conzelmann, Gerhard Friedrich. Göttingen: Vandenhoeck \& Ruprecht, 1976.

Coon, G. A. Good Neighbors Evangelism: Informal Talks Volume 3. Decatur: Mrs. G. A. Coon, Box 449, 1954 .

Cox, Harvey. Stadt ohne Gott. 5th ed. Stuttgart: Kreuz-Verlag, 1969 . 
Cox, Kenneth 0 . "Evangelistic Problems and Suggestions." In Meeting the secular Mind: Some Adventist Perspectives. Selected Working Papers of the Committee on Secularism of the General Conference of Seventh-day Adventists 1981-1985. Edited by Humberto M. Rasi and Fritz Guy. Berrien Springs: Andrews University Press, 1985, pp. 77-83.

Darnell, William A. "Utilizing Laymen in Follow-up Ministry." Southwestern Journal of Theology 17 (1975) : 58-64.

Dibelius, Martin. An die Kolosser, Epheser, an Philemon. Handbuch zum Neuen Testament. Tübingen: J. C. B. Mohr (Paul Siebeck), 1953.

Die Gemeinde, eine Schule für Missionsarbeit - Missionshelferkursus für die Mitteleuropäische Division, Abteilung Heimatmission. Darmstadt: Gemeinschaft der Siebenten-Tags-Adventisten, Mitteleuropäische Division, Abteilung Heimatmission, n. d.

Diehl, William E. Thank God, It's Monday! Philadelphia: Fortress Press, 1982 .

Die induktive Gesprächsführung - studienheft für Kursteilnehmer. Ostfildern: Gemeinschaft der Siebenten-Tags-Adventisten, süddeutscher Verband, n. $d$.

Divine Blueprint--Methods, The. Leadership Series No.2. Washington, D.C.: Home Missionary Department, General Conference of Seventh-day Adventists, n. d.

Dodd, M. E. "The Whole Church at Work in Evangelism." In The Message and Method of the New Evangelism: A Joint statement of the Evangelistic Mission of the Christian Church. Edited by Jesse M. Bader. New York: Round Table Press, 1937.

Doohan, Leonard. "Contemporary Theologies of the Laity: An overview since vatican II." Communio: International Catholic Review 7 (1980):225-242.

Drummond, Lewis A. Leading Your Church in Evangelism. Nashville: Broadman Press, 1975.

Dudley, Roger L., and Cummings, Des. "A study of Factors Relating to Church Growth in the North American Division of Seventh-day Adventists." Review of Religious Research 24 (1983): 322-333. 
Eastwood, Cyril. The Priesthood of All Believers. Minneapolis: Augsburg Publishing House, 1962.

- The Royal Priesthood of the Faithful: An Investigation of the Doctrine from Biblical Times to the Reformation. Minneapolis: Augsburg Publishing House, 1963.

Egan, Gerard. Der fähige Helfer - Grundformen helfender Beziehung. Gelnhausen: Burckhardthaus-Laetare Verlag, 1979.

Ellicott, Charles J. A Critical and Grammatical commentary on st. Paul's Epistle to the Ephesians with a Revised Translation. 2nd ed. London: John Parker and Son, 1859 .

Elliott, John Hall. "Death of a Slogan - from Royal Priests to Celebrating Community." Una Sancta 25 (1968) : 18-31.

- The Elect and the Holy. An Exegetical Examination of 1 Pet $2: 4-10$ and the phrase basileion hierateuma. Leiden: E. J. Brill, 1966.

Emmauel; S. J. "Some Mission Priorities That Determine and Demand New Lay Ministers." Zeitschrift für Missionswissenschaft und Religionswissenschaft 61 (1977):256-270.

Engel, James F. Contemporary Christian Communications: Its Theory and Practice. Nashville: Thomas Nelson Publishers, 1979.

English, Edwin A. "An Evaluation of the concept and Function of Mutual Ministry and Spiritual Gifts in the South Caribbean Conference." D.Min. project, Andrews University, 1974.

Engstrom, S. E. "Evangelism and stewardship." The Lutheran Quarterly 5 (1953):35-38.

Ernst, Josef. Pleroma und Pleroma Christi. Regensburg: Verlag Friedrich Pustet, 1970.

Evangelisation des Predigers im Bezirk - Fortbildungslehrgang Abtenau 1971 und 1972. Stuttgart: Gemeinschaft der Siebenten-Tags-Adventisten, süddeutscher Verband, 1973. 
"Evangelist." Seventh-day Adventist Bible Dictionary. Edited by Siegfried Horn. Rev. ed. Washington, D. C.: Review and Herald Publishing Association, 1979 , p. 346.

Ewald, Paul. Die Briefe des Paulus an die Epheser, Kolosser und Philemon. 2nd ed. Leipzig: A. Deichert'sche Verlagsbuchhandlung Nachf., 1910.

Fairfield, James, ed. Probe for an Evangelism That Cares. Scottdale: Herald Press, 1972.

Finley, Mark. Entscheidungen - Menschen für Christus gewinnen. Hamburg: Advent-Verlag, 1986.

- Studien zur offenbarung - Handbuch für Evangelisation. Bern: Gemeinschaft der SiebentenTags-Adventisten, Euro-Afrika-Division, Predigtamtsabteilung, 1984 .

- "Target and Tactics." In Meeting the secular Mind: Some Adventist Perspectives. Selected Working Papers of the committee on Secularism of the General Conference of Seventh-day Adventists 1981-1985. Edited by Humberto M. Rasi and Fritz Guy. Berrien Springs: Andrews University Press, 1985.

- The Way to Adventist Church Growth. Arroyo Grande: Concerned Communications, n. d.

Fouseca, A. "Secularization and Evangelization." In Evangelization, Dialogue, and Development: Selected Papers of the International Theological Conference, Nagpur (India) 1971. Series: Documenta Missionalia - 5. Rome: Universita Gregoriana Editrice, 1972 .

Fowler, John W. "Helping People Work Together." Ministry, October 1985, pp. 4-7.

Friedrich, Gerhard. "Euaggelizomai." Theological Dictionary of the New Testament. Edited by Gerhard Kittel and Gerhard Friedrich. Grand Rapids: Wm. B. Eerdmans Publishing Company, 1983. 2:707-737.

"keryx." Theological Dictionary of the New Testament. Edited by Gerhard Kittel and Gerhard Friedrich. Grand Rapids: Wm. B. Eerdmans Publishing Company, 1982. 3:683-718. 
Froom, LeRoy Edwin. Movement of Destiny. Washington, D.C.: Review and Herald Publishing Association, 1971 .

Geffré: Claude. "Theological Reflections on a New Age of Mission." International Review of Mission 71 (1982) : 478-492.

"Gesundheit statt Geld." Factum, July/August 1986, p. 30.

Gilkey, Langdon. Society and the Sacred: Toward a Theology of culture in Decline. New York: Crossroad Publishing Company, 1981.

Gnilka, Joachim. Der Epheserbrief. Herders theologischer Kommentar zum Neuen Testament. Freiburg: Herder Verlag, 1971.

Goppelt, Leonhard. Der erste Petrusbrief. Edited by Ferdinand Hahn. Kritisch-exegetischer Kommentar über das Neue Testament. Founded by H. A. W. Meyer. Göttingen: Vandenhoeck \& Ruprecht, 1978.

Gray, J. M. "Evangelist." The International Standard Bible Encyclopedia. Edited by Geoffrey w. Bromiley. Grand Rapids: Wm. B. Eerdmans Publishing Company, 1962. 2:204.

Green, Hollis L. Why Churches Die: A Guide to Basic Evangelism and Church Growth. Minneapolis: Bethany Fellowship, 1972 .

Grengel, Christa, and Mendt, Dietrich, eds. Der Laie in Gemeinde und Kirche - Materialien der Bundessynode vom 13. bis 17. Mai 1977 in Görlitz. Berlin: Evangelische Verlagsanstalt, 1979.

Haarbeck, H. "Evangelisation." Evangelisches Kirchenlexikon - kirchlich-theologisches Handwörterbuch. 2nd ed. Edited by Heinz Brunotte and otto Weber. Göttingen: Vandenhoeck \& Ruprecht, 1961. $1: 1187-1189$.

Hadden, Jeffrey $K$. The Gathering storm in the churches. New York: Doubleday \& Company, 1969.

Hadidian, Didran Y. "Tous de evangelistas in Eph 4:11." Catholic Biblical Quarterly 28 (1966):317-321. 
Hammerly, Hector. "A Strategy for Public Evangelism." In Meeting the Secular Mind: Some Adventist Perspectives. Selected Working Papers of the Committee on Secularism of the General Conference of Seventhday Adventists 1981-1985. Edited by Humberto M. Rasi and Fritz Guy. Berrien Springs: Andrews University Press, 1985.

Handy, R. T. Members one of Another. Valley Forge, Pa.: Judson Press, 1968.

Hao, Yap Kim. "Reden mitten unter dem Tun." In Evangelisation im ökumenischen Gespräch - Beiträge eines Symposiums (Genf 1973). Edited by walter Arnold. Erlangen: Verlag der evangelisch-lutherischen Mission, 1974 .

Harkness, Georgia Elma. The Church and Its Laity. New York: Abingdon Press, 1962.

Harnack, Adolf. The Mission and Expansion of Christianity in the First Three centuries. 2nd ed. London: Williams and Norgate, 1968.

Henrichsen, Walter A., and Garrison, William N. Layman Look Up! God Has a Place for You. Grand Rapids: Zondervan Publishing House, 1983.

Hensey, James. The Layman in the Itinerary. New York: Methodist Book Concern, 1919.

Hiebert, D. Edmond. "Pauline Images of a Christian Leader." Bibliotheca Sacra 133 (1976):213-228.

Hoefler, Richard Carl. creative Preaching and oral Writing. Lima: C. S. S. Publishing Company, 1978.

Holtz, Gottfried. Die Pastoralbriefe. Theologischer Handkommentar zum Neuen Testament. 2nd ed. Berlin: Evangelische Verlagsanstalt, 1972.

Hudson, Stan, and McGavran, Donald. "McGavran on Adventist Church Growth." Ministry, May 1985, pp. 16-19.

Hugedé, Norbert. L'Épitre aux Éphésiens. Geneva: Labot et Fides, 1973 . 
Hunter, George G. "Equipping Church Laity for Evangelistic Ministry." In A Celebration of Ministry:

Essays in Honor of Frank Bateman Stanger. Edited by Kenneth Cain Kinghorn. Wilmore: Francis Asbury Publishing Company, 1982.

- The Contagious Congregation: Frontiers in Evangelism and Church Growth. Nashville: Abingdon, 1979

Ishida, Y. "The Ministry of the People of God." South East Asia Journal of Theology 23 (1982):14i-150.

Jackson, Richard A. "A New Testament Pattern for a Ministry of Evangelism." Southwestern Journal of Theology 17 (1975):30-36.

Japas, Salim. "A Strategy for Seventh-day Adventist Public Evangelism within a Roman Catholic Society Context in Hispanic America." D.Min. project, Andrews University, 1978 .

Johnson, A. M. "Philip the Evangelist and the Gospel of John." Abr-Nahrain. Edited by J. Bowman. Leiden: E. J. Brill, 1976. 16:49-72.

Johnson, Johnny Durant. "The Development and Evaluation of a Program for Bible Evangelism to Be Used by Layman Employing Small-Group Methods as a Basic Format." D.Min. project, Andrews University, 1977.

Johnson, Paul Gordon. Buried Alive. Richmond: John Knox Press, 1968.

Johnson, R. C., ed. The Church and Its Changing Ministry. Philadelphia: Office of the General Assembly --The United Presbyterian Church in the United states of America, 1961.

Johnsson, William G. "The Challenge of Secular Thought." In Meeting the Secular Mind: Some Adventist Perspectives. Selected Working Papers of the Committee on secularism of the General Conference of Seventh-day Adventists 1981--1985. Edited by Humberto M. Rasi and Fritz Guy. Berrien Springs: Andrews University Press, 1985.

Joseph, Samuel H. A Study of the Functions of Ministry and Laity with special Reference to the East Caribbean Conference of Seventh-day Adventists. D. Min. project, Andrews University, 1975. 
Kane, Margaret. Theology in an Industrial society. London: SCM Press, 1975.

Kelley, Alden Drew. The People of God: A study in the Doctrine of the Laity. Greenwich, Ct.: Seabury Press, 1962.

Kelly, J. N. D. A Commentary on the Epistles of Peter and of Jude. New York: Harper \& Row, Publishers, 1969 .

Kencher, William F. Good News People in Action. Valley Forge: Judson Press, 1975.

Kennedy, James. Dynamische Evangelisation. Bad Liebenzell: Verlag der Liebenzeller Mission, 1978.

Knorr, Dr. "Der Dienst der Laien in der Gemeinde." In Laien an die Front! Zeugnisse für den Laiendienst in der Gemeinde. Edited by Oskar Hammelsbeck and Walter Müksch. Wuppertal-Barmen: Verlag "Der Rufer," Hermann Werner, 1938.

Knowles, George E. How to Help your Church Grow. Washington, D. C.: Review and Herald Publishing Association, 1981.

Konferenzbericht über die Jahre 1977 - 1981. Vorgelegt zur Abgeordnetenversammlung des süddeutschen Verbandes am 20. Mai 1982 in stuttgart. Stuttgart: Gemeinschaft der Siebenten-Tags-Adventisten, Süddeutscher Verband, 1982 .

Kraemer, Hendrik. A Theology of the Laity. Philadelphia: Westminster Press, 1958.

Kraus, c. Norman, ed. Missions, Evangelism, and Church Growth. Scottdale: Herald Press, 1980.

Kromminga, Carl Gerhard. The Communication of the Gospel through Neighboring: A Study of the Basis and Practice of Lay witnessing through Neighborly Relationships. Franeker: T. Wever, 1964 .

Kuhne, Gary w. Evangelisation und was dann? Die Dynamik der persönlichen Nacharbeit. Bad Liebenzell: Ver lag der Liebenzeller Mission, 1979.

Küng, Hans. The Church. New York: Sheed and Ward, 1967.

Laici in Ecclesia. Geneva: Published by the Department on the Laity, World Council of Churches, 1961. 
La Laicité. Published by Université d'Aix-Marseille, Centre De Sciences Politiques de l'Institut d'Etudes Jurisdiques de Nice. Paris: Presses Universitaires de France, 1960.

Lambeth Essays on Ministry. Published by the Archbishop of Canterbury. London: S. P. C. K., 1969.

Lay Evangelist's Handbook. Prepared by the Lay Activities Department of the General Conference of Seventhday Adventists. Washington: Review and Herald Publishing Association, 1978.

Lay Training Manual: Emphasizing the Winning, Training, and Sending Men for Jesus christ. Riverside: Department of Layman's Activities, Southeastern California Conference, n. d.

Lehrgang für induktive Gesprächsführung - Anleitung zur Durchführung eines Aufbaukurses. Ostfildern: Ge meinschaft der Siebenten-Tags-Adventisten, süddeutscher Verband, n. d.

Lehrgang für induktive Gesprächsführung - Anleitung zur Durchführung eines Grundkurses. Ostfildern: Gemeinschaft der Siebenten-Tags-Adventisten, Süddeutscher Verband, n. d.

Linberg, Edwin Carl. "An Examination of the Role of the Clergy as an Enabler of the Development and Growth of the Ministry of the Laity." D.Min. project, School of Theology at claremont, 1975.

Lindgren, Alvin J., and Shawchuck, Norman. Let My People Go: Empowering Laity for Ministry. Nashville: Abingdon Press, 1984 .

Lindgren, Alvin J., and Shawchuck, Norman. Management for Your Church. Nashville: Abingdon, 1981.

Listening to Lay People. Published by the National Council of the churches of Christ in the United States of America. New York: Council Press, 1971.

Lloyd-Jones, D.M. Christian Unity: An Exposition of Ephesians $4: 1$ to 16. Grand Rapids: Baker Book House, 1981. 
Lohse, B. "Priestertum. In der christlichen Kirche" Die Religion in Geschichte und Gegenwart. Handwörterbuch für Theologie und Religionswissenschaft. Tübingen: J. C. B. Mohr (Paul Siebeck), 1961. $5: 569-582$.

Lohse, Eduard. "Apostel." In Biblisch-Theologisches Handwörterbuch zur Lutherbibel und zu neueren übersetzungen. Second edition. Edited by Edo Osterloh und Hans Engelland. Göttingen: Vandenhoeck \& Ruprecht, 1959.

Loughborough, J. N. Rise and Progress of the Seventhday Adventists (Battle Creek: General Conference Association of Seventh-day Adventists, 1892.

Margull, J. "Evangelism." Die Religion in Geschichte und Gegenwart - Handwörterbuch für Theologie und Religionswissenschaft. 3rd ed. Edited by Kurt Galling. Tübingen: J. C. B. Mohr (Paul Siebeck), 1958. $2: 795-796$.

Marney, Carlyle. Priests to Each other. Valley Forge: Judson Press, 1974 .

Maxwell, c. Mervyn. Tell It to the World: The story of Seventh-day Adventists. 2nd ed. Mountain View: Pacific Press Publishing Association, 1982.

Mayer, Helmut. "Zeitplan für eine Jahres-Evangelisation im Bezirk." Aller Diener. Stoffsammlungen und Mitteilungen der EAD-Predigtamtsabteilung. Bern: Gemeinschaft der Siebenten-Tags-Adventisten, EuroAfrika Division, 3 (1979):48-52.

McBride, Michael G. "Role Conflict and Role Ambiguity Applicable to the Local Pastor in the North Pacific Conference of Seventh-day Adventists. D.Min. project, Andrews University, 1984.

McGavran, Donald A., and Arn, Winfield C. Ten steps for Church Growth. New York: Harper \& Row, Publishers, 1977 .

Merklein, Helmut. Das kirchliche Amt nach dem Epheserbrief. Studien zum Alten und Neuen Testament. Edited by Vinzenz Hamp und Josef Schmid. Munich: Kösel-Verlag, 1973.

Meyer, Heinrich August wilhelm. Handbuch über den Brief an die Epheser. 6th ed. Göttingen: Vandenhoeck \& Ruprecht's Verlag, 1886. 
Miller, Cyril. "Leadership Evangelism." Ministry, February 1986, pp.8-10.

Miller, C. John. Evangelism and Your Church. Phillipsburg: Presbyterian and Reformed Publishing Company, 1980.

Miller, Hollis Allen. "Developing a Ministry of Evangelism among the Laity in a Southern Lutheran Church: Its Implications for Parish Renewal." D.Min. project, Drew University, 1984 .

Miller, Paul M. Group Dynamics in Evangelism. Scottdale: Herald Press, 1961

Mitchell, Kenneth J., and Savage, John S. Skills for Calling and Caring Ministries. "Learning the Lanquage of Healing." Pittsford: L. E. A. D. Consultants, 1982 .

Moberg, David 0 . The Great Reversal: Evangelism and Social Concern. Rev. ed. Philadelphia: J. B. Lippincott Company, 1977.

Mole, John. "Laymanship." Scottish Journal of Theology 14 (1961): 381-389.

Moltmann, Jürgen. Diakonie im Horizont des Reiches Gottes. Neukirchen-Vluyn: Neukirchener Verlag, 1984 .

Moore, M. E. "The Minister and the People of God." Quarterly Review 3 (1983):33-49.

Moore, Waylon B. New Testament Follow-up: For Pastors and Laymen: How to Conserve, Mature, and Multiply the Converts. Grand Rapids: Wm. B. Eerdmans Company, 1963.

Moran, William L. "A Kingdom of Priests." In The Bible in Current Catholic Thought. Edited by John L. McKenzie. New York: Herder and Herder, 1962.

Moule, Handley C.G. Ephesian Studies: Expository Readings on the Epistle of Saint paul to the Ephesians. London: Hodder and Stoughton, 1900.

Mouw, Richard J. Called to Holy Worldliness. Philadelphia: Fortress Press, 1980. 
Mücksch, P. "Das Amt des Pfarrers und der Laienstand." In Laien an die Front! Zeugnisse für den Laiendienst in der Gemeinde. Edited by Oskar Hammelsbeck and Walther Mücksch. Wuppertal-Barmen: Verlag "Der Rufer", Hermann Werner, 1938.

Mueller, Konrad F. Die Frühgeschichte der SiebentenTags-Adventisten bis zur Gemeindegründung 1863 und ihre Bedeutung für die moderne Irenik. Marburg: N. G. Elwert Verlag, 1969.

Mumma, Howard E. Take It to the People: New Ways in Soul Winning: Unconventional Evangelism. New York: World Publishing Company, 1969.

Mussner, Franz. Der Brief an die Epheser. Ökumenischer Taschenbuchkommentar zum Neuen Testament. Vol. 10. Edited by Erich Gräser and Karl Kertelge. Gütersloh: Gütersloher Verlagshaus Gerd Mohn, 1982 .

Nater, Hans. Mut zum Hauskreis. Gladbeck: Schriftenmissions-Verlag, 1983

Neill, Stephen Charles, and Weber, Hans-Ruedi. The Layman in Christian History. A Project of the Department on the laity of the world council of Churches. Philadelphia: Westminster Press, 1963.

Nötzelmann, Richard. Arbeitsunterlagen zum VerhaltensTraining Rhetorik - wirkungsvoll sprechen, vortragen. Munich: Institut für Berufsbildung, 1979.

Official Recommendations: Department of Lay Activities, 1913-1969. Washington, D.C.: General Conference of Seventh-day Adventists, 1969.

Oosterwal, Gottfried. "The Process of Secularization." In Meeting the secular Mind: Some Adventist Perspectives. Selected Working Papers of the Committee on Secularism of the General Conference of Seventh-day Adventists 1981- 1985. Edited by Humberto M. Rasi and Fritz Guy. Berrien Springs: Andrews University Press, 1985.

Pastor's Guide to Materials for Use in The caring Church, A: Arroyo Grande: Concerned Communications, n. d. 
Patrick, Arthur Nelson. "A study of Methods to Secure and Maintain an Audience in SDA Evangelism." M. Div. Thesis, Andrews University, 1972 .

Paulien, Jon. "The Gospel in the secular World." In Meeting the Secular Mind: Some Adventist Perspectives. Selected Working Papers of the committee on Secularism of the General Conference of Seventhday Adventists 1981-1985. Edited by Humberto M. Rasi and Fritz Guy. Berrien Springs: Andrews University Press, 1985.

Pedro, Arano M. "Methods Affecting Success in EvangeIism." M.A. thesis, Andrews University, 1982.

Petersen, Jim. Evangelism as a Lifestyle. Colorado Springs: Navpress, 1980.

Philip, Abraham. "Mobilization of the Laity in the Mar Thoma Church for Evangelism." D.Miss. dissertation, Fuller Theological Seminary, 1974.

Pippert, Rebecca Manley. Out of the Salt shaker \& into the World: Evangelism as a Way of Life. Downers Grove: Intervarsity Press, 1979.

Potter, Burtt. The Church Reaching out. Durham, North Carolina: Moore Publishing Company, 1976.

Prentner, Regin. "Die göttliche Einsetzung des Predigtamtes und das allgemeine Priestertum bei Luther." Theologische Literaturzeitung 86 (1961):321-332.

- "Priestertun, allgemeines." Die Religion in Geschichte und Gegenwart. Handwörterbuch für Theologie und Religionswissenschaft. 3rd ed. Tübingen: J. C. B. Mohr (Paul Siebeck), 1961. $5: 581-582$.

Rahlenbeck, P. "Evangelisation." Realencyklopädie für protestantische Theologie und Kirche. Edited by Albert Hauck. 3rd ed. Leipzig: J. C. Hinrich'se Buchhandlung, 1898. 5:661-667.

Reed, Jesse s. "our Supreme Service." In Motivating Laymen to witness. Edited by James A. Ponder. Nashville: Broadman Press, 1974.

Rees, Paul S. "I Have My Doubts." World Vision Magazine, January 1971, p. 32 . 
Rendtorff, H. "Evangelisation und Volksmission." Die Religion in Geschichte und Gegenwart - Handwörterbuch für Theologie und Religionswissenschaft. 3rd ed. Edited by Kurt Galling. Tübingen: J. C. Mohr (Paul Siebeck), 1958. 2:770-775.

Richardson, William J. Social Action versus Evangelism: An Essay on the Contemporary Crisis. South Pasadena: William Carey Library, 1977.

Robinson, Haddon $w$. Biblical Preaching: The Development and Delivery of Expository Messages. Grand Rapids: Baker Book House, 1983.

Robinson, William. Completing the Reformation: The Doctrine of the Priesthood of All Believers. Lexington: The College of the Bible, 1955.

Roloff, Jürgen. Apostolat - Verkündigung - Kirche. Ursprung, Inhalt und Funktion des kirchlichen Apostelamtes nach Paulus, Lukas und den Pastoralbriefen. Güterslon: Gütersloher Verlagshaus Gerd Mohn, 1965.

Sandevoir, Pierre. "Un royaume de Prêtres?" Études sur la Premièere Lettre de Pierre. Congrès de l'ACFEB, Paris 1979. Presentation par Charles Perrot. Lectio Divina 102. Paris: Les Éditions du Cerf, 1980 .

Savage. John S. The Apathetic and Bored Church Member: Psychological and Theological Implications. Pittsford: I. E. A. D. Consultants, 1976.

Scales, W. C. "Seven Steps to Church Growth." Administry, Autumn 1982, pp. 4, 14.

Schaller, Lyle E. Assimilating New Members (Nashville: Abingdon Press, 1978).

- Growing Plans - strategies to Increase Your Church's Membership. Nashville: Abingdon Press, 1984 .

Hey, That's Our Church. Nashville: Abingdon Press, 1978.

Schantz, Borge. "Church Growth: Catalyst or Method?" Ministry, December 1985, pp.7-9.

Schelkle, Karl Hermann. "Christi Himmelfahrt." Geist und Leben 41 (1968):81-85. 
Schelkle, Karl Hermann. Die Petrusbriefe, der Judasbrief. Herders theologischer Kommentar zum Neuen Testament. Edited by Alfred Wikenhauser and Anton Vögtle. Freiburg: Herder Verlag, 1970.

Schille, Gottfried. Die Apostelgeschichte des Lukas. Theologischer Handkommentar zum Neuen Testament. Berlin: Evangelische Verlagsanstalt, 1983.

Schilling, 0. "busr." Theological Dictionary of the old Testament. Rev. ed. Edited by Johannes Botterweck and Helmer Ringgren. Grand Rapids: Wm. B. Eerdmans Publishing Company, 1977. 2:313-316.

Schlier, Heinrich. Der Brief an die Epheser. Düsseldorf: Patmos-Verlag, 1957.

- Die Zeit der Kirche. Freiburg: Herder Verlag, 1956 .

Schmauch, W. "Evangelium." Evangelisches Kirchenlexikon kirchlich-theologisches Handwörterbuch. 2nd ed. Edited by Heinz Brunotte and otto Weber. Gottingen: Vandenhoeck \& Ruprecht, 1961. 1:1213-1216.

Schnackenburg, R. "Umschau und Kritik." Biblische Zeitschrift 12 (1968):152-153.

Schneider, Gerhard. Die Apostelgeschichte - II. Teil. Freiburg: Herder Verlag, 1982.

Schniewind, Julius. "Aggelia." Theological Dictionary of the New Testament. Edited by Gerhard Kittel and Gerhard Friedrich. Grand Rapids: Wm. B. Eerdmans Publishing Company, 1983. 1:56-73.

Schniewind, Julius, and Friedrich, Gerhard. "Epaggelia." Theological Dictionary of the New Testament. Edited by Gerhard Kittel and Gerhard Friedrich. Grand Rapids: Wm. B. Eerdmans Publishing Company, 1983. 2:576-586.

Schrenk, Gottlob. "Hierateuma." Theological Dictionary of the New Testament. Edited by Gerhard Kittel and Gerhard Friedrich. Grand Rapids: Wm. B. Eerdmans Publishing Company, 1982. 3:249-251.

Scott, W. M. F. "Priesthood in the New Testament." Scottish Journal of Theology 10 (1957):399-415.

Sequence Evangelism Seminars. Arroyo Grande: Concerned Communications, n.d. 
Sevenster, G. "Het Koning- en Priestershap der Gelovigen in het Nieuwe Testament." Nederlands Theologisch Tijdschrift 13 (1958-59):401-417.

Smith, D. P. "Shared Ministry." Theology Today 36 (1979) : 338-346.

Snyder, H. A. "An Evangelistic Lifestyle for the Congregation." In Missions, Evangelism, and Church Growth. Edited by c. Norman Kraus. Scottdale: Herald Press, 1980.

Snodgrass, Klyne R. "I Peter II.1-10: Its Formation and Literary Affinities." New Testament Studies 24 $(1977-78): 97-106$.

Spicq, P. Ceslas. Les Épitres de Saint Pierre. Sources Bibliques. Paris: Librarie Lecoffre, J. Gabalda et Cie., 1966.

- Saint Paul - Les Épitres Pastorales. Paris: Librairie Lecoffre, J.Gabalda et Cie., 1947.

Sterner, Stephen L. "What Laity Expects of Clergy: A Case Study." D.Min. project, Lancaster Theological Seminary, 1980.

Stott, John R. W. Gesandt wie Christus - Grundfragen christlicher Mission und Evangelisation. Wuppertal: R. Brockhaus Verlag, 1976.

Stout, Kenneth B. "Developing, Implementing, and Testing a Training program for Lay Pastoral Ministry in Selected Churches of the Columbia Union Conference of Seventh-day Adventists." D.Min. project, Andrews University, 1983.

Strachan, Kenneth. The Inescapable Calling. Grand Rapids: Wm. B. Eerdmans Publishing Company, 1968.

strathmann, Hermann. "Martys." Theological Dictionary of the New Testament. Edited by Gerhard Kittel and Gerhard Friedrich. Grand Rapids: Wm. B. Eerdmans Publishing Company, 1983. 4:474-514.

Strathmann, Hermann and Meyer, R. "Laos." Theological Dictionary of the New Testament. Edited by Gerhard Kittel and Gerhard Friedrich. Grand Rapids: Wm. B. Eerdmans Publishing Company, 1983. 1:29-57. 
Stuhlmacher, Peter. Das paulinische Evangelium I.Vorgeschichte. Göttingen: Vandenhoeck \& Ruprecht, 1968 .

Sweazy, George. Effective Evangelism. New York: Harper \& Brothers Publishers, 1953.

Sylvester, Curtis R. "A Model for Lay Ministry Based on the Small Group concept in a Congregation-Wide Setting." D.Min. project, Drew University, 1983.

Thielicke, Helmut. "The Salt, Not the Honey of the World." Leadership 4 (1983):114-119.

Toffler, Alvin. Der Zukunftsschock. Berlin: C. A. Koch's Verlag Nachf., 1970.

Torrance, T. F. Royal Priesthood. Scottish Journal of Theology Occasional Papers No. 3. Edingburgh: Oliver and Boyd, 1963.

Trueblood, Elton. Your Other Vocation. New York: Harper \& Brothers, 1952 .

Ulrich, H.-H. Evangelism in Germany - An Ecumenical study. Published for the World Council of Churches by the United society for Christian Literature. World Evangelism Today Series. London: Lutterworth Press, 1958.

Vanistaendal, August. "A Layman's View of the Future of Mission." In A New Missionary Era. Edited by Padraig Flanagan. New York: Orbis Books, 1979.

Vellanickal, Matthew. "Biblical Theology of Evangelization." In Evangelization, Dialogue, and Development. Selected Papers of the International Theological Conference, Nagpur (India) 1971. Series: Documenta Missionalia - 5. Edited by M. Dhavamony. Rome: Universita Gregoriana Editrice, 1972 .

Wagner, c. Peter. Frontiers in Missionary strategy. Chicago: Moody Press, 1971.

- On the crest of the Wave: Becoming a World Christian. Ventura, California: Regal Book, 1983.

- Your Church Can Grow: Seven Vital signs of a Healthy Church. Ventura: Regal Books, 1984. 
Weeks, Howard B. "Lengthening the cords, strengthening the Stakes (Some Thoughts on an old Theme)."

In Meeting the Secular Mind: Some Adventist Perspectives. Selected Working Papers of the Committee on secularism of the General conference of Seventh-day Adventists 1981-1985. Edited by Humberto M. Rasi and Fritz Guy. Berrien Springs: Andrews University Press, 1985.

Weiss, Bernhard. Die Briefe an Timotheus und Titus Kritisch-exegetischer Kommentar über das Neue Testament. 6th ed. Göttingen: Vandenhoeck \& Ruprecht, 1902 .

Wenn man dich fragt nach deinem Glauben. Hamburg: AdventVerlag, 1986.

Wentz, Frederik K. Getting into the Act: Opening Up Lay Ministry in the Weekday World. Nashville: Abingdon, 1978 .

- The Layman's Role Today. New York: Doubleday \& Company, 1963.

White, Ellen G. Colporteur Ministry. Mountain View: Pacific Press Publishing Association, 1953.

- Counsels on Health and Instruction to Medical Missionary Workers. Mountain View: Pacific Press Publishing Association, 1941

- Counsels to Teachers, Parents, and students Regarding Christian Education. Mountain View: Pacific Press Publishing Association, 1938.

- Evangelism. Washington, D. C.: Review and Herald Publishing Association, 1970.

- The Ministry of Healing. Mountain View: Pacific Press Publishing Association, 1942.

Testimonies for the Church. 9 vols. Mountain View: Pacific Press Publishing Association, 1948.

Wiebe, P. W. "Preaching Evangelism." In Probe for an Evangelism That Cares. Edited by J. Fairfield. Scottdale: Herald Press, 1972.

Windisch, Hans. Die katholischen Briefe. 2nd ed. Handbuch zum neuen Testament. Tübingen: Verlag von $J$. C. B. Mohr (Paul Siebeck), 1930. 
Winter, Ralph D. "The Kingdom Strikes Back: The Ten Epochs of Redemptive History." In Perspectives on the world Christian Movement. Edited by Ralph D. Winter and Steven C. Hawthorne. Pasadena: William Carey Library, 1983.

. "The Task Remaining." In Perspectives on the World Christian Movement. Edited by Ralph D. Winter and Steven C. Hawthorne. Pasadena: William Carey Library, 1983.

Winter, Ralph D., and Hawthorne, Steven C., eds. Perspectives on the World Christian Movement - A Reader. Pasadena: William Carey Library, 1983.

Wohlenberg, G. Der erste und zweite Petrusbrief und der Judasbrief. 1st and 2nd ed. Leipzig: A. Deichert' sche Verlagsbuchhandlung Werner Scholl, 1915.

Yeakley, F. R. "Views of Evangelism." In The Pastor's Church Growth Handbook. Vol. 2. Edited by Winfield Arn. Pasadena: Church Growth Press, 1982.

Zahn, Theodor. Skizzen aus dem Leben der Alten Kirche. $3 r d$ ed. Leipzig: A. Deichert'sche Verlagsbuchhandlung Nachf. (Georg Böhme), 1908 .

Zamora, Robert M. "The Gospel of the Abundant Life." In Meeting the Secular Mind: Some Adventist Perspectives. Selected Working Papers of the Committee on Secularism of the General Conference of Seventhday Adventists 1981-1985. Edited by Humberto M. Rasi and Fritz GuY. Berrien Springs: Andrews University Press, 1985.

Zikmund, Barbara Brown. "Christian Vocation--in Context." Theology Today 36 (1979):328-337. 
VITA

Ekkehardt Müller was born December 25, 1950, in East Germany. In 1956 he and his family escaped to west Germany. After finishing high school, which in Germany takes nine years after four years of elementary school, he attended Seminar Marienhöhe in Darmstadt, West Germany, to become a pastor. In 1972 he finished with a B.A. equivalent and was employed as a pastor by the south Bavarian Conference of Seventh-day Adventists. Since that time he has been pastoring several churches, including a larger church within the city of Munich. In Munich, he took a course in Hebrew at the Ludwig-Maximillians-University to improve his Hebrew. In 1983 he continued his education at Andrews University and graduated with a M.Div. degree in 1985. Almost at the same time he finished his D.Min. classwork. Since the fall 1985 he has been pastoring a two-church district in the city of Munich. 